\title{
DEFINING A RESEARCH TOOL: AN OBJECT-BASED STUDY OF A GROUP OF INTER-RELATED PHOTOGRAPHIC OBJECTS ATTRIBUTED TO THE JAMES INGLIS STUDIO (1866 - 1884) \\ IN THE McCORD MUSEUM, MONTREAL
}

\author{
by \\ Michelle Macleod \\ Bachelor of Fine Arts, \\ Concordia University, Montreal, Canada, 2008

\begin{abstract}
A thesis
presented to Ryerson University

in partial fulfillment

of the requirements for the degree of

Master of Arts

in the Program of

Photographic Preservation \& Collections Management
\end{abstract}

Toronto, Ontario, Canada, 2012

(C) Michelle Macleod 2012 



\section{AUTHOR'S DECLARATION FOR ELECTRONIC SUBMISSION OF A THESIS}

I hereby declare that I am the sole author of this thesis. This is a true copy of the thesis, including any required final revisions, as accepted by my examiners.

I authorize Ryerson University to lend this thesis to other institutions or individuals for the purpose of scholarly research

I further authorize Ryerson University to reproduce this thesis by photocopying or by other means, in total or in part, at the request of other institutions or individuals for the purpose of scholarly research

I understand that my thesis may be made electronically available to the public. 



\title{
DEFINING A RESEARCH TOOL: \\ AN OBJECT-BASED STUDY OF A GROUP OF \\ INTER-RELATED PHOTOGRAPHIC OBJECTS \\ ATTRIBUTED TO THE JAMES INGLIS STUDIO (1866 - 1884) \\ IN THE McCORD MUSEUM, MONTREAL
}

by

Michelle Macleod

\begin{abstract}
This thesis is a case study of 39 disbound album pages with 579 albumen photographic portraits, most attributed to James Inglis (1835-1904), an accompanying index book, four related documents, and two notes concerning the objects' provenance. This object-based examination of these objects is intended to serve as a model for photographic and social historians when presented with inter-related, multi-part photographic objects.

This extensively illustrated case study, which is supported by four appendices, reveals aspects of Montreal's social history in the late nineteenth century and facilitates the objects incorporation into the McCord Museum's collection. A brief biography and information on Inglis' studio are included to contribute to the study of his career and nineteenth century portraiture in Montreal. While the exact function of these objects is still uncertain, this thesis explores their overall intellectual and historical value and is intended to foster further research in the collection.
\end{abstract}





\section{ACKNOWLEDGEMENTS}

This thesis would not have been possible without the guidance and the help of several individuals who in one way or another contributed and extended their valuable assistance in the preparation and completion of this study.

First and foremost, I would like to thank my supervisor Dr. David Harris. His tremendous knowledge, excellent guidance, patience and enduring enthusiasm for solving this "puzzle" served as a constant source of inspiration and motivation. A special thanks is extended to Mike Robinson for taking the time to review my work. I also owe my deepest gratitude to the director of the Photographic Preservation \& Collections Management program, Dr. Marta Braun, as well as the extended faculty of the program.

To the McCord Museum, and its remarkable staff, to whom I am indebted to for the production of this work, thank you. Specifically, Dr. Hélène Samson, who not only awarded me the opportunity to work in the McCord Museum's collection but continued her willingness to help and patience throughout this project. Special thanks also to Nora Hague, Céline Widmer, Heather McNabb, Marilyn Aitken and Stéphanie Poisson at the McCord Museum.

I owe sincere and earnest thankfulness to Dr. Irwin Reichstein, who shared his research and insight on James Inglis with me from the very beginning. Thank you as well to Christopher Lyons, Liaison Librarian of the Osler Library of the History of Medicine at McGill University for your help.

Fellow classmates, I am so grateful to have met all of you and cannot wait to see what becomes of this talented group. Friends and extended family, thank you for being there with for me with equal parts of loving support and much needed distraction. To my family, Mom, Dad and Scott, I cannot even begin to express how grateful I am to have been given this opportunity to follow my passion. Thank you for your unwavering support and love. 

To My Family

"Hold Fast" 



\section{TABLE OF CONTENTS}

Introduction

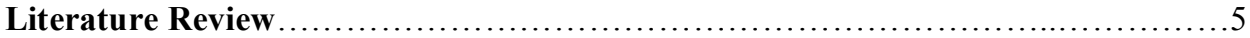

Object-Based Photographic History ....................................... 5

Photographic Albums with Related Material................................... 7

Commercial Photography............................................... 9

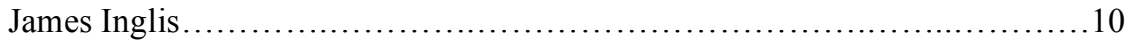

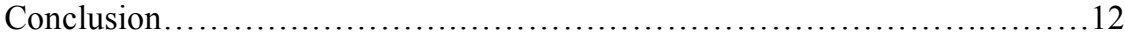

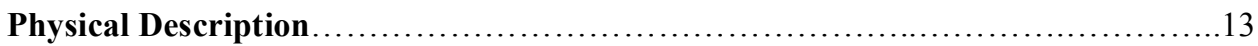

Album Pages............................................................... 13

Index Book............................................................ 18

Related Documents................................................ 23

Provenance Notes......................................................26

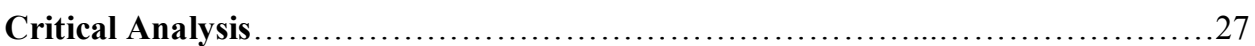

Body of Work

Album Pages........................................................ 28

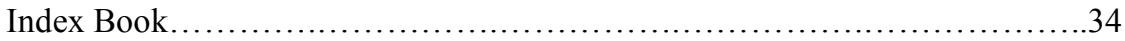

Related Documents................................................... 37

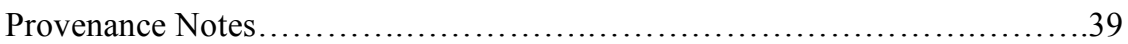

Intellectual Organization

Relationship between Album Pages and Index Book.......................41

Relationship between Album Pages and Related Documents................. 51

Relationship between the Index Book and Related Documents................52

Attribution of the Photographs.......................................... 55

Dating the Objects............................................... 66

Original and Subsequent Functions................................ 81

James Inglis' Biography ................................................ 85

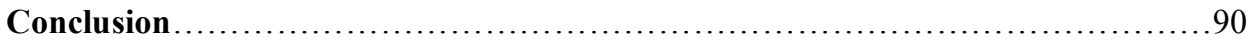

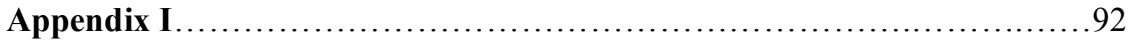

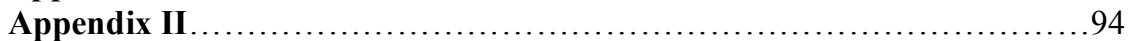

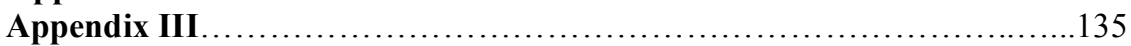

Appendix IV ..................................................... 140

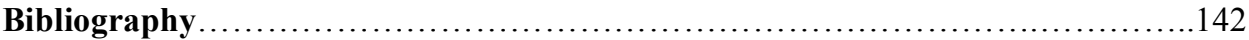





\section{LIST OF ILLUSTRATIONS}

1. Album page \#33, recto, annotated by the author," album page: $27.3 \times 44.5 \mathrm{~cm}$, with ten mounted albumen photographs, each approximately $5 \times 7 \mathrm{~cm}$, McCord Museum Collection, M15955.

2. “Album page \#16, recto," album page: $27.3 \times 44.5 \mathrm{~cm}$, with ten mounted albumen photographs, each approximately 5 x $7 \mathrm{~cm}$. McCord Museum Collection, M15955.

3. "Index Book Front Cover," marbled paper, 10 x $31 \mathrm{~cm}$, McCord Museum Collection, M15955.

4. "Index Book, Page D," lined paper pages, 10 x $31 \mathrm{~cm}$, McCord Museum Collection, M15955.

5. "Index Book, page D, annotated by the author," lined paper pages, 10 x $31 \mathrm{~cm}$, McCord Museum Collection, M15955.

6. "Related Document \#2, annotated by the author," paper, $21 \times 13.5 \mathrm{~cm}$, McCord Museum Collection, M15955.

7. "Marjorie Howard-Futcher Album, Page 1," album page: 27.3 x $44.5 \mathrm{~cm}$, McGill University Library, Osler Library of Medical History, http://digital.library.mcgill.ca/futcher/collection.php

8. "Marjorie Howard-Futcher Album, back cover, close-up," album page: 27.3 x 44.5 cm, maker's mark: approx. 5 x 7 cm, McGill University Library, Osler Library of Medical History, http://digital.library.mcgill.ca/futcher/collection.php

9. Franklin H. Gilson. 1897. Separable Book. U.S. Patent 594,203, filed February 15, 1897, issued November 23, 1897, 1. Source: United States Patent and Trademark Office Website, URL:

http://patimg1.uspto.gov/.piw?docid=00594203\&PageNum=1\&IDKey=918A6895 A871\&HomeUrl=http://patft.uspto.gov/netacgi/nph-

Parser?Sect $2=\mathrm{PTO} 1 \% 2526 \mathrm{Sect} 2=\mathrm{HITOFF} \% 2526 \mathrm{p}=1 \% 2526 \mathrm{u}=/$ netahtml $/ \mathrm{PTO} / \mathrm{sear}$ ch-

bool.html $\% 2526 \mathrm{r}=1 \% 2526 \mathrm{f}=\mathrm{G} \% 25261=50 \% 2526 \mathrm{~d}=\mathrm{PALL} \% 2526 \mathrm{~S} 1=0594203 . \mathrm{PN}$. $\% 2526 \mathrm{OS}=\mathrm{PN} / 594203 \% 2526 \mathrm{RS}=\mathrm{PN} / 594203$

10. “Index Book, Page A," lined paper page, 10 x $31 \mathrm{~cm}$, McCord Museum Collection, M15955.

11. “P. D. Dods, Montreal, QC, 1863” by William Notman, albumen Print, 8.5 x 5.6 cm McCord Museum Collection, I-6656.1.

12. “P.D. Dods, Album Page \#12, Image 3," albumen Print, 5 x 7 cm, McCord Museum Collection, M15955. 

13. "Mr. Date, Album Page \#12, Image 2," albumen print, 5 x $7 \mathrm{~cm}$, McCord Museum Collection, M15955.

14. "Henry H. Date, Montreal, $Q C, 1863$ " by William Notman, albumen print, $8.5 \mathrm{x}$ $5.6 \mathrm{~cm}$ McCord Museum Collection, I-6988.1.

15. "Mrs. Sharpley, Album Page \#22, Image 6," albumen print. 5 x $7 \mathrm{~cm}$, McCord Museum Collection, M15955.

16. "Henry Morgan, Album Page \#20, Image 5," albumen print, 5 x $7 \mathrm{~cm}$, McCord Museum Collection, M15955.

17. "Henry Morgan, Montreal, QC, about 1875 " by James Inglis, albumen print, 5 x 8 $\mathrm{cm}$, McCord Museum Collection, MP-1991.21.

18. "Prince Arthur, Album Page \#33, Image 3," albumen print, 5 x $7 \mathrm{~cm}$, McCord Museum Collection, M15955.

19. "H.R.H. Prince Arthur, in Winter Dress. Photo by Inglis" by James Inglis in Canadian Illustrated News, No. 23, p. 357, April 9th, 1870, dimensions unknown, Leggotype process.

20. "Victoria Rifles, Montreal, QC, composite by James Inglis, 1870" by James Inglis, albumen print, 32 x $47 \mathrm{~cm}$ McCord Museum Collection, MP-1986.21.

21. "Col Crawford, Album Page \#30, Image 10", albumen print, 5 x $7 \mathrm{~cm}$, McCord Museum Collection, M15955.

22. Close-up of "Victoria Rifles, Montreal, QC, composite by James Inglis, 1870" by James Inglis, albumen print, 32 x $47 \mathrm{~cm}$ McCord Museum Collection, MP1986.21 .

23. "James W. Pyke, Montreal, QC, about 1870" by James Inglis, negative number: 26897, albumen print, 10.1 x $6.2 \mathrm{~cm}$, McCord Museum Collection, MP0000.116.6.

24. "J. G. Parks advertisement," in The International Railway and Steam Navigation Guide, Montreal: C. R. Chrisolm \& Bros., August 1875, pg. 58.

25. “J. G. Parks advertisement," in Vennor's Almanac and Weather Record, Montreal: J. Lovell \& Son, 1878-79, pg. 19.

26. "Hon. Beaugrand, Album Page \#17, Image 11," albumen print, 5 x 7 cm, McCord Museum Collection, M15955. 

27. “Ovilgie Dead, Album Page \#11, Image 3," albumen print, 5 x 7 cm, McCord Museum Collection, M15955.

28. “John Ogilvie, Montreal, QC, 1880” by William Notman, albumen print.8.5 x 5.6 cm McCord Museum Collection, II-55161.1.

29. "James Inglis, photographer, Montreal, QC, 1866" by William Notman, albumen print, 8.5 x $5.6 \mathrm{~cm}$ McCord Museum Collection, I-21789.1. 



\section{LISTS OF APPENDICES}

Appendix I: Concordance of the Disbound Album Pages

Appendix II: Catalogue of Identified Portraits in Disbound Album Pages

Appendix III: Transcriptions of the Related Documents

Appendix IV: Negative Number Correlations between the Disbound Album Pages and Related Documents 



\section{INTRODUCTION}

In recent decades, the history of photography has been substantially restructured by researchers and curators who have called for a discipline that is autonomous from Art History. This is mainly because photography lends itself to the production of many objects that fall outside the canon of traditional Art History. Gaining momentum in the 1980's and 1990's, this re-conceptualization of photography's history led to increased scholarly interest in such neglected objects as carte-de-visites, cabinet cards, and, among others, photographic albums, in order to construct a fuller history of the medium. Photographic albums, the subject of this thesis, were mass-produced to meet the demands of consumers from the mid-nineteenth to the twentieth century, and their intellectual and historical value lies in the way they were personalized as well as in the evidence of how they were used and organized. In light of this, photographic historians have established a more appropriate research methodology - the study of photographs has become the study of photographic objects. This methodological shift seeks neither to ignore or diminish the image content of a photograph but to engage it with the entire object.

This thesis provides a case study of this approach on a group of objects in the McCord Museum in Montreal, Canada. Initially a historical institution, the museum's collection grew out of David Ross McCord's (1844-1930) personal collection, "whose abiding wish was to shed light on the history and cultures of his country." Inaugurated in 1921 as "The David Ross McCord Historical Museum" and administered by McGill University until 1981 before becoming a public museum, the McCord Museum became and remains the guardian of Montreal's social history and material culture. The body of

\footnotetext{
1 “The McCord Museum - Its History,” McCord Museum, accessed July 20, 2012, http://www.mccordmuseum.qc.ca/en/info/collection/
} 
work chosen for this thesis was transferred from McGill University's Library in 1922 as the museum was establishing its collection. The transferal consisted of 39 disbound album pages, which contain a total of 579 albumen photographic portraits, an accompanying index book, four corresponding documents and two notes concerning the objects' provenance.

In Verna Posever Curtis' recent publication Photographic Memory: The Album in the Age of Photography, she argues that, "albums have their own place in the history of photography." ${ }^{2}$ This thesis extends Curtis' work by studying a group of disbound album pages, which has an accompanying index and related documents. The incorporation of an album's related material into the analysis will result in a more complete understanding of the objects and therefore more concretely situate such albums into the history of photography. Albums with related material are not uncommon. Yet, as the ensuing literature review will illustrate, albums with accompanying indexes and documents have not been analyzed in depth by scholars in this revised historiography of photography. It is envisioned that this thesis will serve as a model for photographic and social historians when presented with an album that has accompanying indexes and documents.

First, a thorough physical description of each inter-related object is conducted to align with this relatively new object-based methodology. Using qualities that physically exist within the objects as the kernel of research, instead of relying on the assigned terminology for the objects, will draw more accurate conclusions about the nature of the photographic objects themselves as well as propose educated hypotheses about their organization and overall use.

\footnotetext{
${ }^{2}$ Verna Posever Curtis, Photographic Memory: The Album in the Age of Photography (Washington: Library of Congress; New York: Aperture, 2011), 7
} 
Next, the Critical Analysis chapter of this thesis distills this information gleaned from the physical description of the album pages, the index book, and the related documents. This chapter is divided into five sections. The first examines each component of the group of objects. The second section discusses the relationships between each component in order to understand the intellectual organization of the entire body of work. A hypothesis about the objects' relation to one another led to the reordering of the disbound album pages and the identification of many of the portraits in the disbound album pages. This research methodology, which involved cross-referencing the portraits with holdings in the McCord Museum's extensive photographic collection, is described at length. A catalogue of both the album page's order and the identifications are included as appendices to this thesis. The large majority of the portraits are of prominent Montreal citizens, including wealthy merchants, bankers, politicians and clergymen. As a result of this research, numerous portraits from the album pages can now be attributed to James Inglis (1835 -1904) and his studio, which was active in Montreal between 1866 and 1884. Thus, the third section is an analysis of information about Inglis' studio, which has been garnered specifically from this group of portraits. Here, some of the photographs, which can be definitely linked to the James Inglis Studio, are described and the group of objects is also used to investigate the negative number system used by the studio. Two more appendices concerning negative numbers found within the group of objects are related to this section. The fourth section of the Critical Analysis chapter builds upon these findings and investigates the different and often multiple date ranges associated with the group of objects. The fifth and final section discusses the objects' trajectory through time and space, and the way in which their functions and purposes have changed. 
In addition to contributing to the history of photographic albums, this case study simultaneously reveals aspects of Montreal's social history in the second half of the nineteenth century. James Inglis was relatively successful in his day and was one of William Notman's (1826 - 1891) fiercest competitors. A brief biography and discussion of Inglis' career, follows the Critical Analysis chapter, which contributes, to a better understanding of Montreal studio photography in the nineteenth century. Since this group of objects had not previously been researched by McCord Museum curatorial staff before this thesis, the resulting work will facilitate the objects' incorporation into the museum's collection and help define the objects' future function as a research tool in this context. 


\section{LITERATURE REVIEW}

This chapter surveys the related literature that pertains to the four major subjects that are addressed in this thesis. The first section discusses object-based photo-historical methodologies. The second section reviews literature on photographic albums to demonstrate the need for a case study on an album, in this case disbound, which has related material. Since the photographs from the disbound album pages are formal studio portraits, the third section is an analysis of publications on nineteenth century commercial photography with an emphasis on studio portraiture. Finally, the fourth section is a survey of the primary and secondary literature by and about James Inglis, as the majority of the portraits in the disbound album pages can be attributed to his studio.

\section{Object-based Photographic History}

One of the most significant resources on object-based photographic history is the 2004 collection of essays by photographic historians, curators, and researchers titled Photographs, Objects, Histories, edited by Elizabeth Edwards and Janice Hart. Both curators and university professors, Edwards and Hart recognized the overlooked importance of photographic materiality and created a volume that treats photographs as "both images and physical objects that exist in time and space and thus in social and

cultural experience." 3 In the introduction of this collection of essays the editors state: "For many decades writing on photography has resonated with references to the photograph as object. These references have made tantalizing and fleeting appearances,

\footnotetext{
${ }^{3}$ Elizabeth Edwards and Janice Hart, ed., Photographs, Objects, Histories: On the Materiality of Images, "Introduction" (London; New York: Routledge, 2004), 2
} 
never to be pursued fully or systematically"4 The essays presented in this publication each develop original methodological strategies for an object-based approach to photographic history.

An earlier example of an object-based approach to the history of photography can be found in Ilsen About and Clement Cheroux's 2001 article, "L'histoire par la photographie" in Études Photographiques, a peer-reviewed journal, published by the Société française de photographie that addresses history of photography and visual culture. Here, the authors advocate "a history by photography, instead of just a history of photography." ${ }^{, 5}$ About and Cheroux state that photographic archives are not being used to their full historical potential. The authors criticize historians for using only the image of a photograph instead of examining the entire object. They outline a methodology for an improved practice, which includes an increased awareness of a photograph's materiality. Using photographs and photographic albums of the Holocaust from a number of archives as their examples, About and Cheroux explain the importance of examining the entire photographic object: "Négliger cette cohérence de l'objet photographique revient à oublier que l'image s'inscrit dans un contexte qui fait sens, que les relations se construisent entre les images d'une même page, que celle-ci participe à une narration ou à un discours qui s'écrit au fil de l'album." 6 The authors also advise that an investigation of the entire photographic object can result in uncovering information that completely changes one's perception and understanding of the image.

\footnotetext{
${ }^{4}$ Ibid, 2-3

${ }^{5}$ Ilsen About and Clément Chéroux, "L'histoire par la photographie", Études photographiques, 10 (November 2001): accessed on 12 July 2012, URL : http://etudesphotographiques.revues.org/index261.html.

${ }^{6}$ Ilsen About and Clément Chéroux, "L'histoire par la photographie", Études photographiques, 10 (November 2001): accessed on 12 July 2012, URL : http://etudesphotographiques.revues.org/index261.html.
} 


\section{Photographic Albums with Inter-Related Material}

There are a number of recent publications on the topic of photographic albums, including Martha Langford's, Suspended Conversations: The Afterlife of Memory in Photographic Albums, ${ }^{7}$ Barbara Levine and Stephanie Snyder's, Snapshot Chronicles: Inventing the American Photo Album, ${ }^{8}$ Patrizia Di Bello's, Women's Albums and Photography in Victorian England: Ladies, Mothers, and Flirts, ${ }^{9}$ Elizabeth Siegel's, Galleries of Friendship and Fame: a History of Nineteenth-century American Photograph Albums, ${ }^{10}$ Stephen Bann, ed., Art and the Early Photographic Album ${ }^{11}$ and Verna Posever Curtis', Photographic Memory: The Album in the Age of Photography. ${ }^{12}$ These publications explore, for the most part, photographic albums that assemble material of personal interest, which were arranged and embellished with care and personal preference. Whether it is a nineteenth century hand-painted women's album of friends and family, a twentieth century snapshot album of vacation photographs or a twenty-first century album creatively assembled by an artist, the function of these albums is clear and the organization, while unique to each, is relatively straightforward. What is also clear from this survey is that albums with related material, like an index book, have not received the same scholarly attention.

Two of the essays in Photographs, Objects, Histories also discuss photographic

\footnotetext{
${ }^{7}$ Langford, Martha. Suspended conversations: The Afterlife of Memory in Photographic Albums (Montreal: McGill-Queen's University Press, 2001).

${ }^{8}$ Barbara Levine and Stephanie Snyder, Snapshot Chronicles: Inventing the American Photo Album. Exhibition catalogue (New York: Princeton Architectural Press; Portland Oregon: Douglas F. Cooley Memorial Art Gallery, Reed College, 2006).

${ }^{9}$ Patrizia Di Bello, Women's Albums and Photography in Victorian England: Ladies, Mothers, and Flirts (Aldershot, UK: Ashgate, 2007).

${ }^{10}$ Elizabeth Siegel, Galleries of friendship and fame: A History of Nineteenth-Century American Photograph Albums (New Haven [Conn.]: Yale University Press, 2010).

${ }^{11}$ Stephen Bann, ed., Art and the Early Photographic Album (Washington, D.C.: National Gallery of Art, 2011).

${ }^{12}$ Curtis, Photographic Memory: The Album in the Age of Photography.
} 
albums, Alison Nordström's, "Making the Journey: The Tupper scrapbooks and the travel they describe" and Glenn Willumson's, "Making Meaning: Displaced Materiality in the Library and Art Museum". These essays focus on groups of objects, which include albums, but they do not include inter-related objects, meaning objects that have a direct relationship with one another. One essay in Photographs, Objects, Histories does tackle this, Edward and Hart's, "Mixed Box: The Cultural Biography of a Box of 'Ethnographic' Photographs." Instead of focusing on one photographic object, the authors consider an entire archival box from the Pitt Rivers Museum at the University of Oxford. Labeled "Box 54" from the museum's "Mixed Geographical" series in the photograph collection, the box contains 203 mounted photographs. The introduction of this essay clearly states the author's intentions for this undertaking,

It explores how, by enclosing specific photographs in conjunction with one another, materiality becomes integral to the meanings of images. We hope to demonstrate how, through seeing photographs as material objects to which things happen, we might come closer to understanding ways in which photographs operate as visual objects within the discursive practices of, in this case, anthropology and anthropological museums. ${ }^{13}$

The authors classify "Box 54" as a "synthetic object" - meaning an object that has been assembled by the institution. The contents were not originally intended to be related to the rest of the contents of the box, but as Edwards and Hart argue, the implications of grouping the objects together can not overlooked - it becomes part of their materiality and meaning. This same idea will be applied to the McCord Museum's disbound album pages, the index book and the related documents: even though they were, at some earlier

\footnotetext{
${ }^{13}$ Elizabeth Edwards and Janice Hart. Photographs, Objects, Histories: On the Materiality of Images, "Mixed Box: the cultural biography of a box of 'ethnographic' photographs", (London; New York: Routledge, 2004), 41
} 
time, created in relationship to one another outside of the museum's context, they now function as a group within the museum's context.

\section{Commercial Photography}

Since all of the 579 photographs adhered to the disbound album pages are formal nineteenth century studio portraits, a review of literature on the topic of commercial photography is required. The literature reveals the conventions of commercial photography in the nineteenth century. McCauley's exhibition catalogue for Likenesses: Portrait Photography in Europe, 1850-1870, which was held at the Art Museum of the University of New Mexico in 1981, is an excellent review of the repeating stylistic characteristics found in nineteenth century studio portraits. She tracks the period's conventions in posing, accessories and backdrops, facial expressions, dress and studio lighting and argues that, "conventions seem to have outlived necessity." 14 Across the twenty-year span of her investigation she reveals that the conventions were slow to change - a discovery, which is pertinent to understanding the portrait conventions in the group of objects chosen for this case study.

Many of the photographs in the disbound album pages can be attributed to the James Inglis Studio, a Montreal portrait studio that was active from 1866 to 1884 , thus a solid understanding of how portrait studios in Montreal operated is essential. There is no better way to grasp this than to consult the literature on William Notman and his very successful portrait studio in Montreal in the second half of the nineteenth century. ${ }^{15}$ There

\footnotetext{
${ }^{14}$ Elizabeth Anne McCauley, Likenesses: Portrait Photography in Europe, 1850-1870, Exhibition catalogue, (Albuquerque: Art Museum/University of New Mexico, 1981).

${ }^{15}$ It should be noted that Notman Photographic Company also had franchise studios in Ottawa, Ontario (The Notman Studio; 1868 - 1872), in Toronto, Ontario (Notman and Fraser; 1868 - 1880), in Halifax,
} 
are four major publications on Notman: Portrait of a Period: A Collection of Notman Photographs, $1856-1915,{ }^{16}$ William Notman: The Stamp of a Studio, ${ }^{17}$ William Notman's Studio: The Canadian Picture ${ }^{18}$ and The World of William Notman: The Nineteenth Century through a Master Lens. ${ }^{19}$ All of these publications have been written, co-written or edited by Stanley G. Triggs, the former curator of photography at the McCord Museum, where The Notman Studio archives resides. While these in depth analyses of Notman's biography and business neglect to discuss other Montreal studio photographers of the time, they do provide a contextual framework for the James Inglis Studio by providing insight into the portrait conventions and business operations of the most successful studio in the same city.

\section{James Inglis Studio}

In 1897 James Inglis wrote a manual entitled Artistic Lighting, ${ }^{20}$ which was published by The Photo-Beacon Co.. The purpose of this book was to share Inglis' knowledge and technical skill in lighting portrait sitters. The manual was republished in 1905, due to popular demand, a year after James Inglis died. ${ }^{21}$ Although this book was published after Inglis had moved from Montreal to Rochester, New York, it attests to the

\footnotetext{
Nova Scotia (The Notman Studio; c. 1869 - 1923), in St. John, New Brunswick (The Notman Studio; 1872

- 1890), in Boston, Massachusetts (Notman and Campbell; c1877 - 1880) and Albany, New York (c1877 1898). For further information on these studios, see Stanley Triggs, The Man and the Studio, "Notman Expands his business", online article, Virtual Museum Canada, (McCord Museum, 2005).

${ }^{16}$ J. Russell Harper and Stanley Triggs, Ed., Portrait of a Period: A Collection of Notman Photographs, 1856-1915 (Montreal: McGill University Press, 1967).

${ }^{17}$ William Notman: The Stamp of a Studio, edited by Stanley Triggs, (Toronto: Art Gallery of Ontario 1985).

${ }^{18}$ Stanley Triggs, William Notman's Studio: The Canadian Picture, (Montreal: McCord Museum, 1992).

${ }^{19}$ Roger Hall, The World of William Notman: The Nineteenth Century through a Master Lens, edited by Gordon Dodds, Stanley Triggs. (Toronto: McClelland \& Stewart, 1993).

${ }^{20}$ James Inglis, Artistic Lighting, (Chicago: The Photo-Beacon Co, 1897)

${ }^{21}$ James Inglis and Todd F. Dundas. Artist Lighting, to which is added, "At Home" Portraiture with Daylight and Flashlight (Chicago: The Photo-Beacon, 1905)
} 
consistent and successful lighting and compositions found in the portraits of the disbound album pages. In the introduction of the manual, Inglis attributes his lighting abilities to his former employee, William Raphael (1833-1914), who was a former employee of the William Notman Studio. Thus, this book also provides insight into the close-knit and highly competitive community of photography studio staff in Montreal in the nineteenth century.

Inglis also frequently participated in competitions held by photographic journals, whose overall purposes were to share techniques and showcase advancements in this burgeoning industry. Competitions in journals were common because they encouraged photographers to be more innovative. One example of Inglis' competitive triumphs is from the very popular journal Philadelphia Photographer in 1869 . He received praise for his two negatives and prints of boating scenes (made in the studio) that he submitted in the journal's competition for the "Genre or Composition Prize." The entry reads, "J. Inglis, Montreal - Two negatives, $4 \frac{3}{4} \times 6 \frac{1}{2}$, of little children floating a boat. The negatives show a high order of photography. The subject is almost too ambitious for photography to reach. Prints excellent in every way",22 Inglis work is also praised in other nineteenth century photographic journals, such as, The Photo-Beacon and Wilson's Photographic Magazine. This demonstrates how innovated Inglis was, and how well known and respected he was in the world of commercial photography.

Inglis is mentioned by Ralph Greenhill in the first edition of Early Photography in Canada $^{23}$ from 1965 as well as the second edition, Canadian Photography: 1839-

\footnotetext{
${ }^{22}$ Edward L. Wilson, ed, “Award of the Prizes: Competitors for the Genre or Composition Prize," The Philadelphia Photographer, 6, no. 71 (November 1869): 361

${ }^{23}$ Ralph Greenhill, Early Photography in Canada, (Toronto: Oxford University Press, 1965).
} 
1920, ${ }^{24}$ which was co-authored Andrew Birrell in 1979. In both books, an advertisement from The Philadelphia Photographer, is quoted which boasts that the James Inglis Studio had, "real water, a pool of which is always kept under the skylight ready for use" for recreating boating scenes. ${ }^{25}$ This shows how Inglis was creative in his endeavors. Greenhill and Birrell's brief mention of him in their book(s) validates that Inglis is a small but distinctive part of early Canadian photographic history.

Dr. Irwin Reichstein has written a two-part article ${ }^{26}$ entitled, James Inglis Montreal, Rochester, Chicago, in Photographica Canadiana, the Photographic History Society of Canada's monthly publication. Reichstein, a professor at Carleton University with a passion for nineteenth century studio photographers, has pieced together the scattered history of Inglis through many primary records and has created a narrative of his life and career, which has been a tremendous resource in understanding this photographer.

\section{Conclusion}

In light of the recent object-based approach, and the existing literature on photographic albums and nineteenth century, commercial studio portraiture, especially in the context of Montreal, this thesis seeks to systematically investigate the materiality of each component of a group of inter-related photographic objects and reveal how they now operate together within the historical discursive space of the McCord Museum.

\footnotetext{
${ }^{24}$ Ralph Greenhill and Andrew Birrell, Canadian Photography: 1839-1920, (Toronto: Coach House Press, 1979).

${ }^{25}$ Ralph Greenhill, Early Photography in Canada, "Elevating the Art" (Toronto: Oxford University Press, 1965) 45.

${ }^{26}$ Reichstein, Irwin. "James Inglis, Montreal, Rochester, Chicago". Part 1. Photographica Canadiana. (March/April 1997): 5-9, and Reichstein, Irwin. "James Inglis, Montreal, Rochester, Chicago". Part 2.

Photographica Canadiana. (May/June 1997): 6-10
} 


\title{
PHYSICAL DESCRIPTION
}

In this chapter the four components of the body of work, the disbound album pages, the index book, the related documents, and the notes concerning the provenance, are thoroughly described, in this order. In the following Critical Analysis chapter, each component is analyzed with this physical description in mind, in the same order again. Due to the multiple complex components of the body of work, a specific terminology was developed by the author to describe the different visual and written components of the objects; these are identified in annotated illustrations in order to aid comprehension and lessen any confusion. This terminology is specific to this thesis, and is not used by the McCord Museum.

\begin{abstract}
Album Pages
The 39 disbound album pages are all made of thick grey cardboard, measuring $27.3 \times 44.5 \mathrm{~cm}$ (ill. 1; pg. 16). The majority of the album pages are in good condition. However, one page in particular, (ill. 2; pg. 17) has ragged edges on the top, right and bottom edges of the cardboard. All the album pages have a strip of stiff canvas glued along the left edge with two small vertical slots, approximately $1.5 \mathrm{~cm}$ in length, one descending from the top and one rising from the bottom of the page. On the top left side of canvas edges of each page are handwritten numbers in pencil, running from 1 to 39 . These numbers, labeled "Album Page Identity Numbers" in Illustration 1, were not in numerical order when research for this thesis began. ${ }^{27}$ Inscribed in ink on the top right corner on the recto of all the pages is the McCord's Accession Number, M15955. A number of the pages have sporadic pencil inscriptions either above or below the

\footnotetext{
${ }^{27}$ See Appendix I for the original and revised order of the album pages, pg. 92
} 
photographs. These include names of individuals or short runs of numbers, as seen on the annotated illustration of Album page \#33 (ill. 1; pg. 16).

Each album page has a maximum of ten albumen photographic portraits, all approximately $5 \times 7 \mathrm{~cm}$, adhered on both the recto and verso of the cardboard, resulting in a maximum of twenty photographs for each page, and an overall total of 579 photographs. However, the actual number of adhered photographs differs from page to page. The majority of recto and verso sides of the pages have a complete set of ten, arranged in two rows of five, but some have fewer photographs; for example, Album page \#28 has only four portraits on the recto and none on the verso. This inconsistency in the number of photographs per page occurs in a variety of combinations throughout the stack of disbound pages.

The photographic portraits are primarily of men, but there are several woman included. On some pages, there are multiple portraits of the same sitter, usually appearing next to one another on the album pages; for example on Album Page \#33 (ill. 1; pg. 16), there are six portraits of Prince Arthur, Duke of Connaught and Strathearn (Arthur William Patrick Albert; $1850-1942),{ }^{28}$ which can be seen in the five portraits that make up the top row of photographs and the first portrait on the bottom row. All of the photographs are formal nineteenth century, commercial studio portraits in which the subjects are rigidly posed amongst elaborate interior surroundings, created with heavy drapery, carved wooden furniture and painted backdrops. The settings and furniture are occasionally repeated throughout these photographs, indicating that these portraits were taken in the same studio. The albumen photographs are in relatively good condition. Most

\footnotetext{
${ }^{28}$ The basis for the identification of these portraits to Prince Arthur will be discussed in the next chapter.
} 
have lost their original eggplant purple color, have yellowed in the highlights, and present a sepia-brown hue overall. 
Illustration 1:

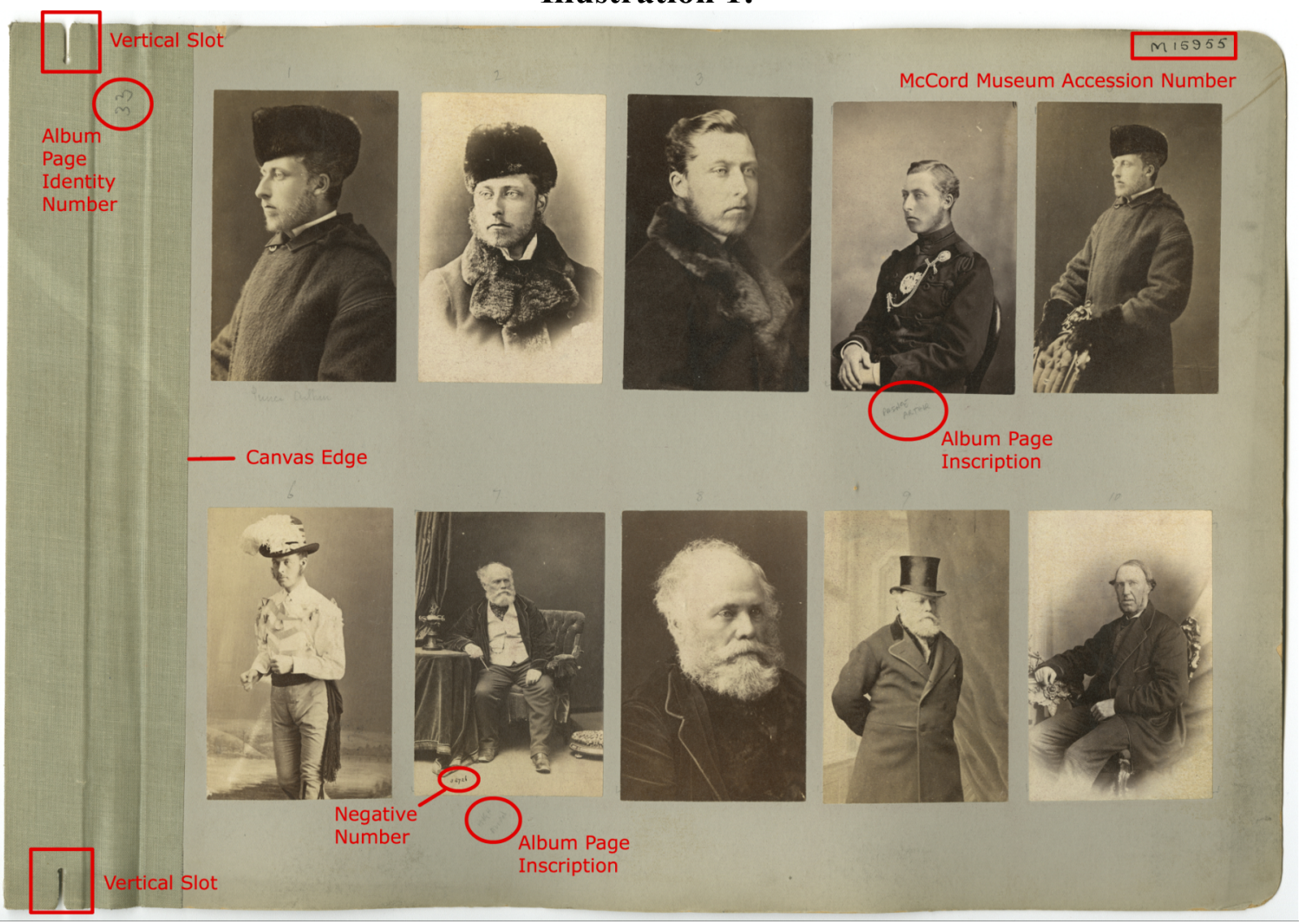

Album page \#33, recto, annotated by the author," album page: $27.3 \times 44.5 \mathrm{~cm}$, with ten mounted albumen photographs, each approximately $5 \times 7 \mathrm{~cm}$. McCord Museum Collection, M15955. 


\section{Illustration 2:}

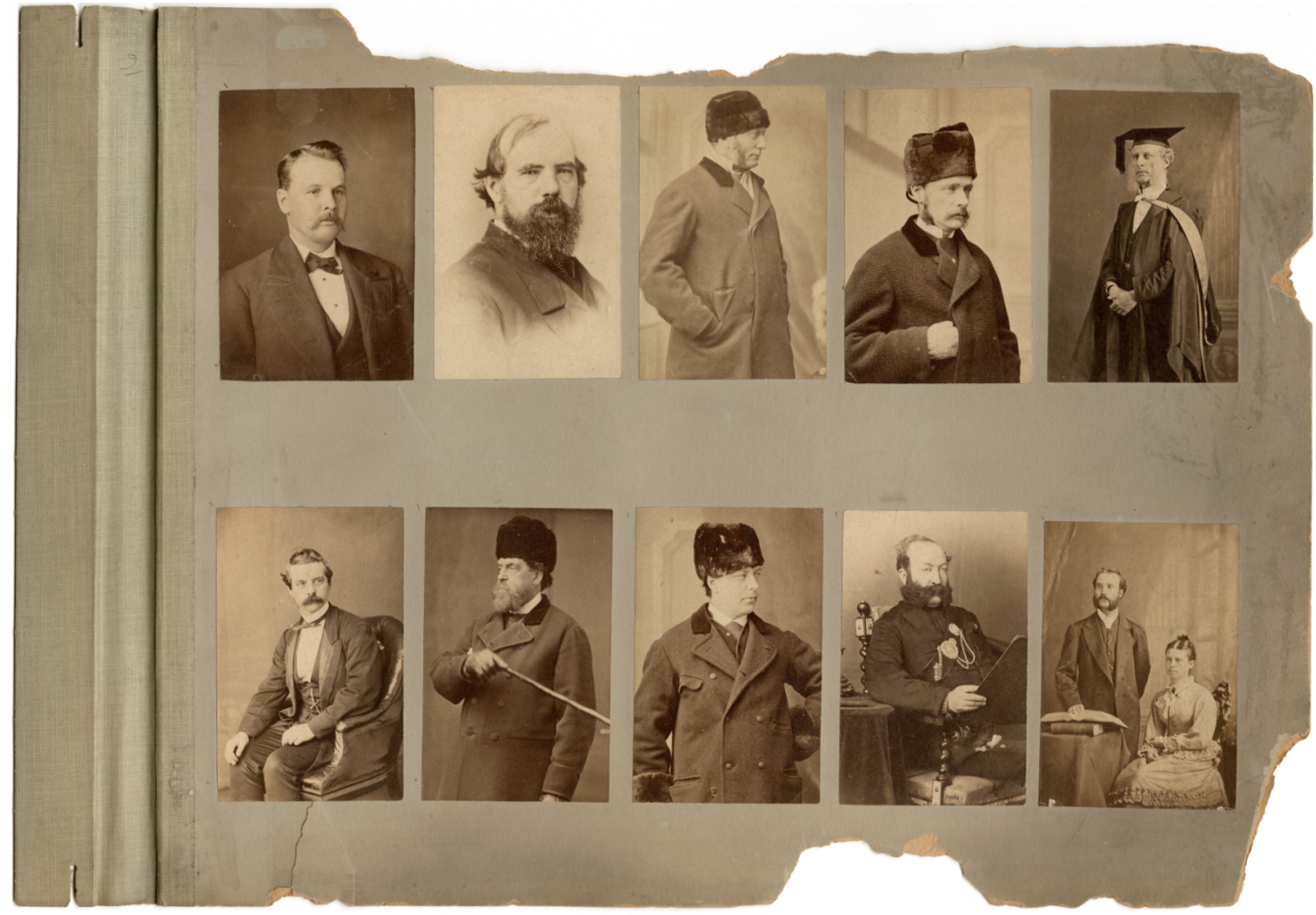

“Album page \#16, recto," album page: 27.3 x $44.5 \mathrm{~cm}$, with ten mounted albumen photographs, each approximately 5 x $7 \mathrm{~cm}$. McCord Museum Collection, M15955. 


\section{Index Book}

The paperback cover of the index book is a made of a pink and turquoise colored marbled paper and is $10 \times 31 \mathrm{~cm}$ (ill. 3; pg. 20). There are no manufacture's marks or labels on the book. The pages within the index book are lined and slightly yellowed. The index book has descending alphabetic tabs on the left side, with an extra "Mc" page appearing after the " $\mathrm{M}$ " page. The letters " $\mathrm{J}$ ", " $\mathrm{X}$ " and " $\mathrm{Z}$ " are missing from the alphabetical tabs. Inscribed in ink on the top right corner of Page A is the McCord's Accession Number, M15955. An annotated illustration of a part of Page D (ill. 4; pg. 21) from the index book indicates the terminology given to the visual and written components of the index book (ill. 5; pg. 22).

The surnames and some first names or initials of individuals are inscribed in black ink throughout the index book. The cursive handwriting with a right-leaning slant is illegible in a few cases. Apart from being allocated to the right alphabetical pages; these names are not in alphabetical order, as can be noted in illustration 5. Included next to some of the individual's surnames, initials or first names is a brief, usually only one word description, of their occupation.

To the left and right of the surnames there are three separate sets of numbers. The first set of numbers are on the left side of the surnames, which are also inscribed in black ink; these are designated "Left Side Numbers" in illustration 5. These numbers range between 1 and 6 . In most cases, however, the most common number is the number 1 . The second set consists of the numbers on the right side of the pages, which are also in ink and range between 1 and 8 , although the majority of them are the number 1 too; these are designated "Right Side Numbers" in illustration 5. The third set is made up of numbers, 
inscribed in pencil, which usually appear between the names and the "Right Side Numbers". This series of numbers has been labeled "Portrait Sequence Numbers" in illustration 5, and will be discussed at length in the Critical Analysis chapter (pg. 27). These numbers start at 1 at the top of the "A" page, and end at 609 at the bottom of the "Y" page, the last page in the index book. The numbers, while not in strict numerical order, do increase as one proceeds through the alphabetic tabs.

Lastly, there are additional intermittent pencil inscriptions throughout the index book pages. These are labeled, "Tentative Locator Inscriptions" in illustration 5 - a term that will also be discussed in the Critical Analysis chapter (pg. 27). These inscriptions follow a formula, which consists of a number, followed by a dash, followed by another number. Some have the letter "P" in front, as can be seen in the middle "Tentative Locator Inscription" in illustration 5. Other inscriptions have the letters "bk" written after the last number, as seen in the middle "Tentative Locator Inscription" identified in illustration 5 . 


\section{Illustration 3:}

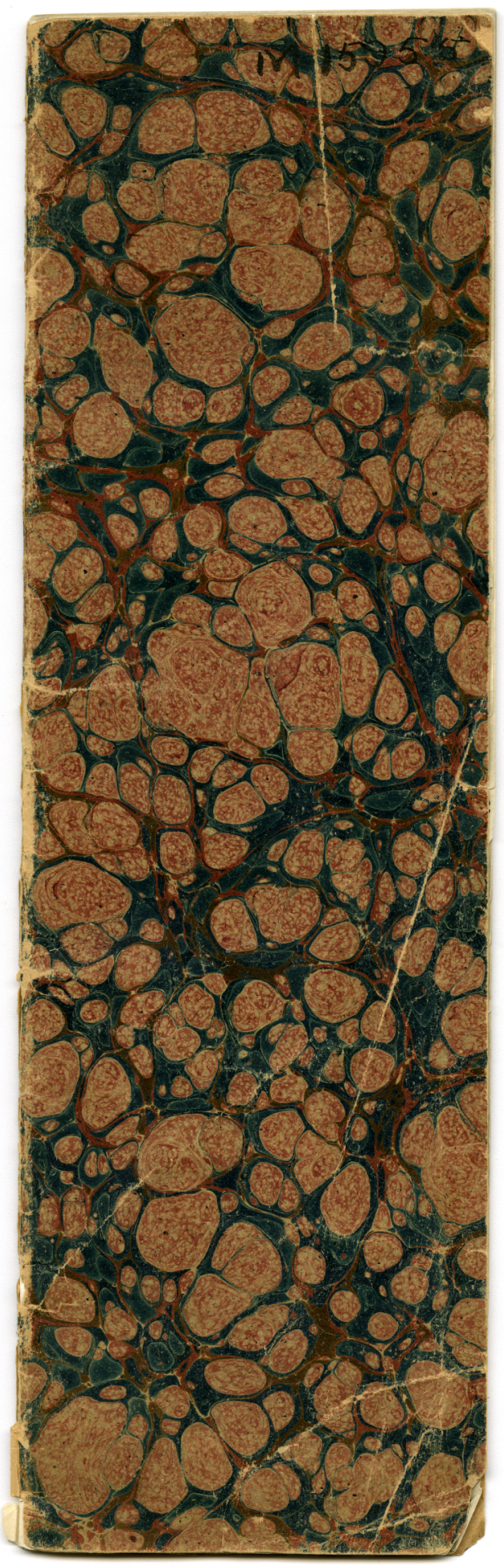

"Index Book Front Cover," marbled paper, 10 x $31 \mathrm{~cm}$, McCord Museum Collection, M15955. 


\section{Illustration 4:}

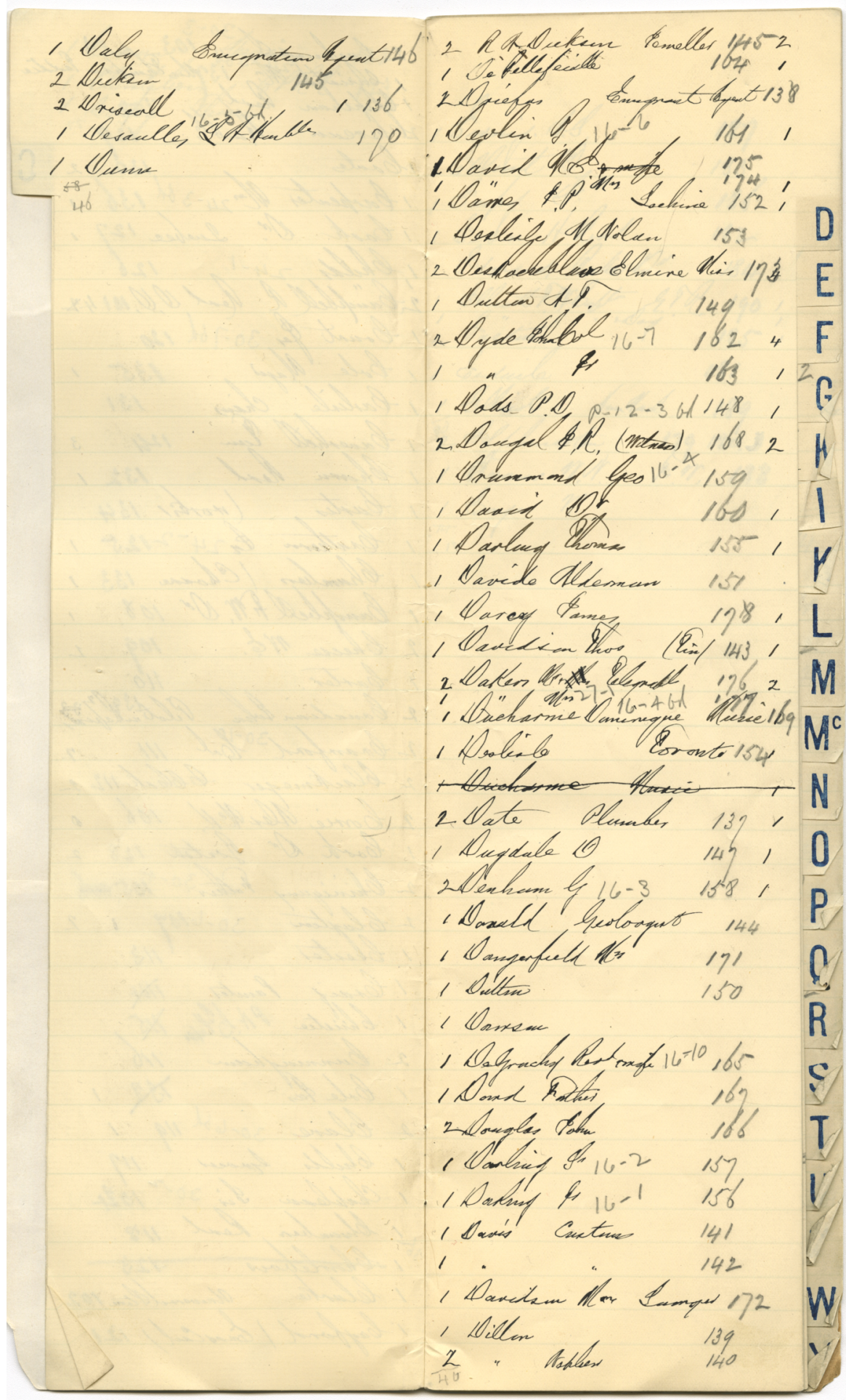

“Index Book, Page D," lined paper pages, 10 x $31 \mathrm{~cm}$, McCord Museum Collection, M15955. 


\section{Illustration 5:}

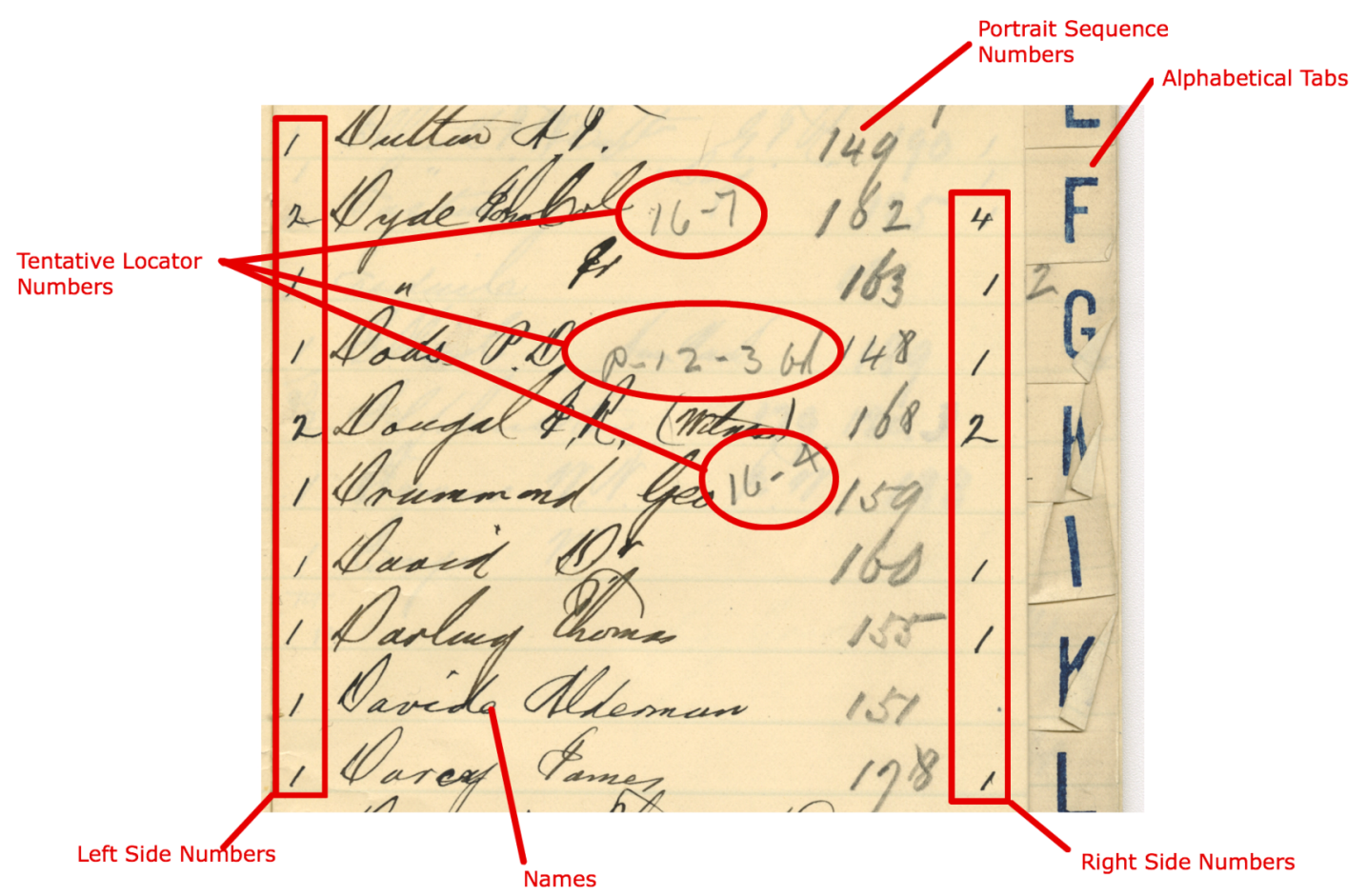

"Index Book, page D, annotated by the author," lined paper pages, 10 x $31 \mathrm{~cm}$, McCord Museum Collection, M15955. 


\section{Related Documents}

In addition to the 39 disbound album pages and the index book, there are four documents in the form of four folded sheets of paper that now formed part of this group. Three of the related documents are $21 \times 13.5 \mathrm{~cm}$ in size, and the fourth is smaller, $13.5 \mathrm{x}$ $13.5 \mathrm{~cm}$. Each document has been numbered 1 through 4 . This number is inscribed in pencil several times at the top of the document. In the annotated illustration of one of the related documents, (ill. 6; pg. 25) this number can be seen three times at the top of the page and is designated as "Related Document Identifier Number". All four documents have been inscribed in ink with the same McCord Accession Number, M15955, as has each album pages and the index book. The three larger sheets of paper have been folded in three, and the smaller in two. The fold lines have been used to demark columns for small handwritten pencil lists of numbers with corresponding names next to them. There are an average of 25 numbers and corresponding names in each column. Also, next to some of the numbers and corresponding names are small pencil check marks.

As shown in illustration 6, the lists consist of numbers with five, three or two digits. The lists of numbers are organized so that the three and two digit numbers are written underneath the last three or two digits of the five digit numbers. For this reason the five digit numbers are labeled "Lead Numbers" and the three and two digit numbers are labeled "Following Numbers". The "Lead Numbers" run from 29412 to 39522, but with large gaps, in numerical order across the four sheets. The "Following Numbers" below the "Lead Numbers", do not follow numerical order. 
Also, on the verso of related document $\# 1$ and $\# 2$ there are typed correspondences. One is from Thomas A. Rodger, M.D., addressed to an unknown "Sir". It reads,

I am given to understand that at the Annual Meeting of the Governors of the Montreal General Hospital in May next, there will be a vacancy in the Surgical Staff of the out-door department ; [sic] and I beg leave to solicit your support at that meeting towards my appointment as ASSISTANT SURGEON to the Hospital.

The letter is located and dated, "Montreal, $19^{\text {th }}$ Feb, 1890 ". The other is written by T.

Johnson Alloway, M. D., addressed to an unknown "Sir" again and is located and dated, “Montreal, Feb $18^{\text {th }}, 1890 . "$ It reads,

At the last quarterly meeting of the Governors of the Montreal General Hospital, a notice of motion was given to amend the By-Laws, so as to add an assistant specialist in the "Department of Diseases of Woman".

I may state that ever since my appointment as ASSISTANT SUREGON to the hospital, three years ago, I have been doing the work now proposed, in association with Dr. William Gardener.

In view of the proposed addition to the staff of this department, I respectfully beg to solicit your support at the Annual Meeting in May next

These correspondences will be discussed further in the Critical Analysis chapter as a way to date the objects. 


\section{Illustration 6:}

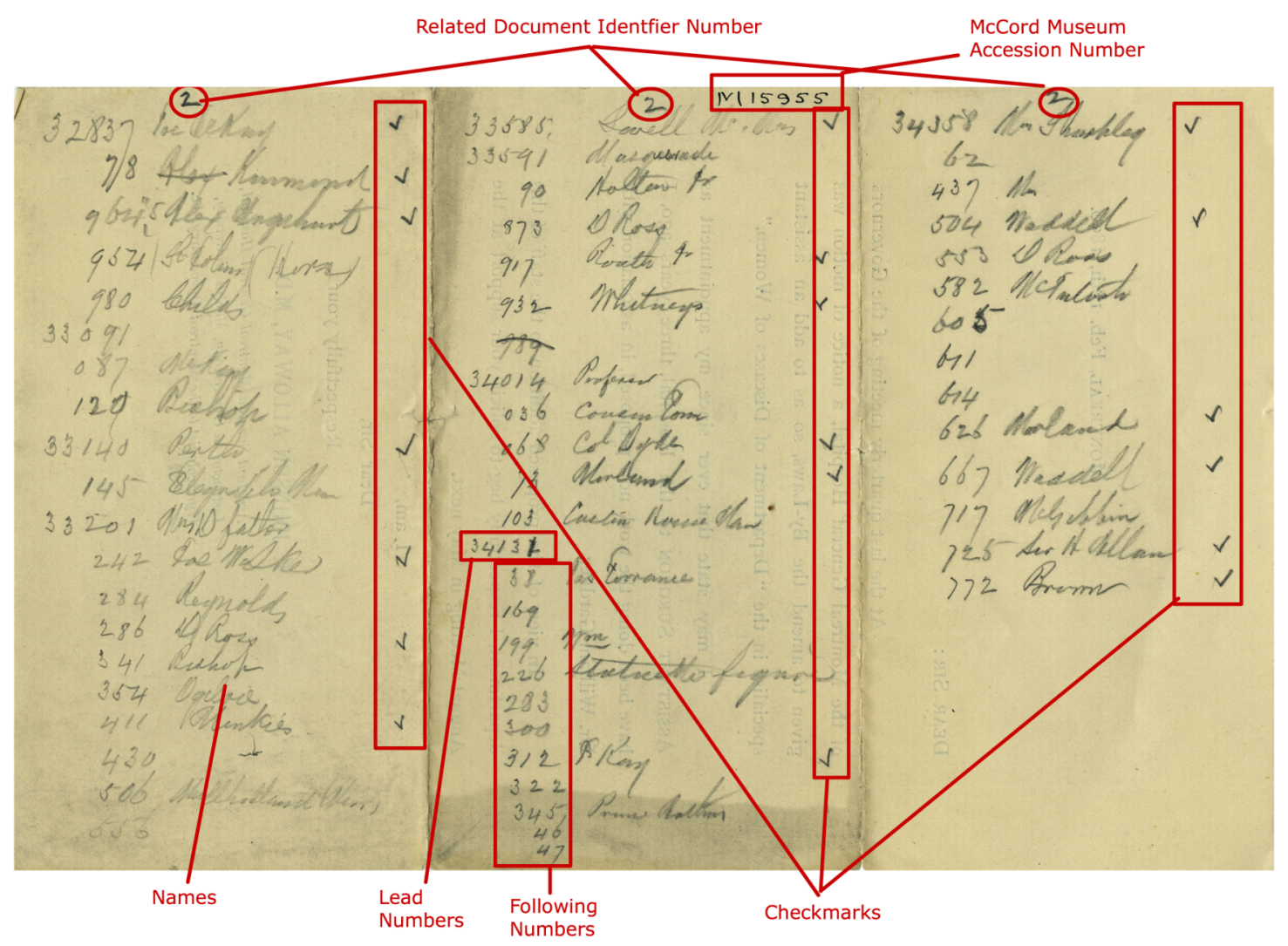

"Related Document \#2, annotated by the author," paper, 21 x $13.5 \mathrm{~cm}$, McCord Museum Collection, M15955. 


\section{Provenance Notes}

The group of objects also includes two administrative notes. One is a handwritten note on stationary of "Gerhard R. Lomer, M.A, Ph.D, Librarian, McGill University Library" stating that some of the objects were transferred from McGill University Library to The David Ross McCord Historical Museum on March $1^{\text {st }}, 1922$. The note outlines that the transferal consisted of, "39 sheets with mounted photographs, 1 envelope with unmounted photographs, 1 index". The envelope of unmounted photographs is presently unaccounted for in the McCord Museum's collection. The second note has been typed on a typewriter on a small piece of paper. It states,

\section{M15955}

Quote from Accession Book,

"Thirty-nine sheets with Montreal photographs of presumably Montrealers - with some of them identified and partial index. (Note in pencil p.no.16 is missing) [sic]

Received June 31932

Source: McGill University

These two notes provide insight into the institutional history of this group of objects, which is discussed in the Critical Analysis chapter of this thesis.

This detailed physical description of the body of work shows just how complex multi-part photographic objects that are inter-related can be. There are many working parts to be analyzed, and each element must be carefully considered in order to understand how this group of objects works together and, thereby, to accurately employ it as a research tool within the McCord Museum's collection. 


\section{CRITICAL ANALYSIS}

The goal of this chapter is to demonstrate the nature and quality of the intellectual value that can be gleaned from an in-depth physical description and understanding of these photographic objects. First, the purpose and significance of each component - the album pages, the index book and the related documents - will be explained through related research. Next, the intellectual organization of this group of objects will be explored in order to understand how the objects may have functioned at different times in the past. This entails discussing the relationship of the album pages to index book, the album pages to the documents, and the index book to the documents. Then, the third section is an investigation into the attribution of the portraits. Photographs that are definitely attributed to the James Inglis Studio are identified and described and then they are employed to further explore the negative number system used by the studio. Then, in the fourth section, all of this information is used to establish an approximate date range this material - the negative dates of the photographs, the print dates for the photographs, and the date when these photographs were assembled on the album pages. Finally, the objects' changing functions through time and space will be considered by exploring various scenarios in which these disbound album pages, index book, and documents were possibly created and how they were used. These five sections represent the type of information that can be extracted from multi-part, inter-related photographic objects, and provide the background for this acquisition's current use as a research tool within the McCord Museum's collection. 


\section{Body of Work}

\section{Album Pages}

The disbound album pages required further research in order to understand how they might have functioned. The first, most obvious physical aspect is that they are now disbound. The canvas edge on the left side of the pages and the two vertical slots at the top and bottom imply that they were once bound. The construction of these pages is, however, not indicative of a standard bookbinding technique. It resembles the screw-post binding technique, which "is a non-adhesive method of binding loose sheets of paper using two-piece binding screws, or posts." ${ }^{, 29}$ This technique, however, requires a hole in the pages, not a slot, to keep the binding intact.

Extensive research uncovered another album with the same binding construction at McGill University's Osler Library of Medical History in Montreal, (ill. 7; pg. 31). This photographic album once belonged to Marjorie Futcher-Howard, "the youngest child of Dr. Robert Palmer Howard, a distinguished McGill University medical professor."30 The album holds dozens of twentieth-century snapshots of the "social life of a young, uppermiddle class Montreal woman and her circle of friends." 31 The only similarities that this album and the disbound album pages in the McCord have in common are the actual pages. The thick, grey cardboard pages are the same size and color and also have the same binding construction on the left side. Fortunately, the Futcher-Howard album has the original front and back covers. On the inside of the back cover there is a small manufacture's mark (ill. 8; pg. 32) that reads,

\footnotetext{
${ }^{29}$ Heather Weston, Bookcraft: Techniques for Binding, Folding, and Decorating to Create Books (London: Quarto Publishing, 2008), 42.

30 “The Marjorie Howard Futcher Photo Collection,” McGill University Library, accessed July 20, 2012, http://digital.library.mcgill.ca/futcher/biography.php.

31 "The Marjorie Howard Futcher Photo Collection."
} 
Gilson Adjustable Album ... Manufactured Solely for THE CARTER'S INK CO., by the F. H. Gilson Co., Patentees. BOSTON, NEW YORK, CHICAGO, LONDON, BRUSSELS. U.S. Patents May 6, 1890, and June 22, 1897. Patented in Great Britain, France, Germany, Belgium, and Canada. ${ }^{32}$

Since the disbound album pages match the album pages of Futcher-Howard it can be deduced that it too was originally bound or was intended to be bound as a Gilson Adjustable Album.

The informative manufacture's mark on the Futcher-Howard album served as an excellent resource of how the pages were once bound together. The Osler Library's album is still intact with the original covers, but it is fragile. A string has been threaded through holes on the top and bottom of the stiff leatherette back cover, the flexible spine cover, the slots in the pages, back through the spine cover and finally through the holes in a front cover made of the same stiff leatherette. The two ends were then tied in a knot in the front. The string is knotted in several places and comprises of both red and white colored string. The original U.S. patent for F. H. Gilson's album was found on the United States Patent and Trademark Office website. Fortunately it has an accompanying diagram (ill. 9; pg. 33) of how the cover pieces and pages, or leaves as they are referred to, were designed to be held together. Instead of string, a "continuous rubber band adapted to encircle the end of the book" 33 was intended to hold together the pages and the covers. Since rubber becomes brittle as it deteriorates, it is likely that this is the reason why the Osler Library's album currently has string instead.

According to the patent for the Gilson Adjustable Album this rubber band, "renders it possible to quickly take the book apart and assemble it and also to quickly and

\footnotetext{
32 "The Marjorie Howard Futcher Photo Collection."

${ }^{33}$ Franklin H. Gilson. 1897. Separable Book. U.S. Patent 594,203, filed February 15, 1897, issued November 23, 1897.
} 
easily insert a leaf or leaves or remove the same." ${ }^{34}$ This would explain why some of the 39 album pages have more physical damage than others. Perhaps the more damaged pages have been in use as part of this once-bound album longer than some of the others.

As previously discussed, the pencil numbers on the top left corner of on the disbound pages are not in numerical order. While the reason for this is unknown, they do, however, give each page a unique identifier, which is labeled, "Album Page Identity Numbers" in the Album Page \#33 diagram (ill. 1; pg. 16).

${ }^{34}$ Ibid. 
Illustration 7:

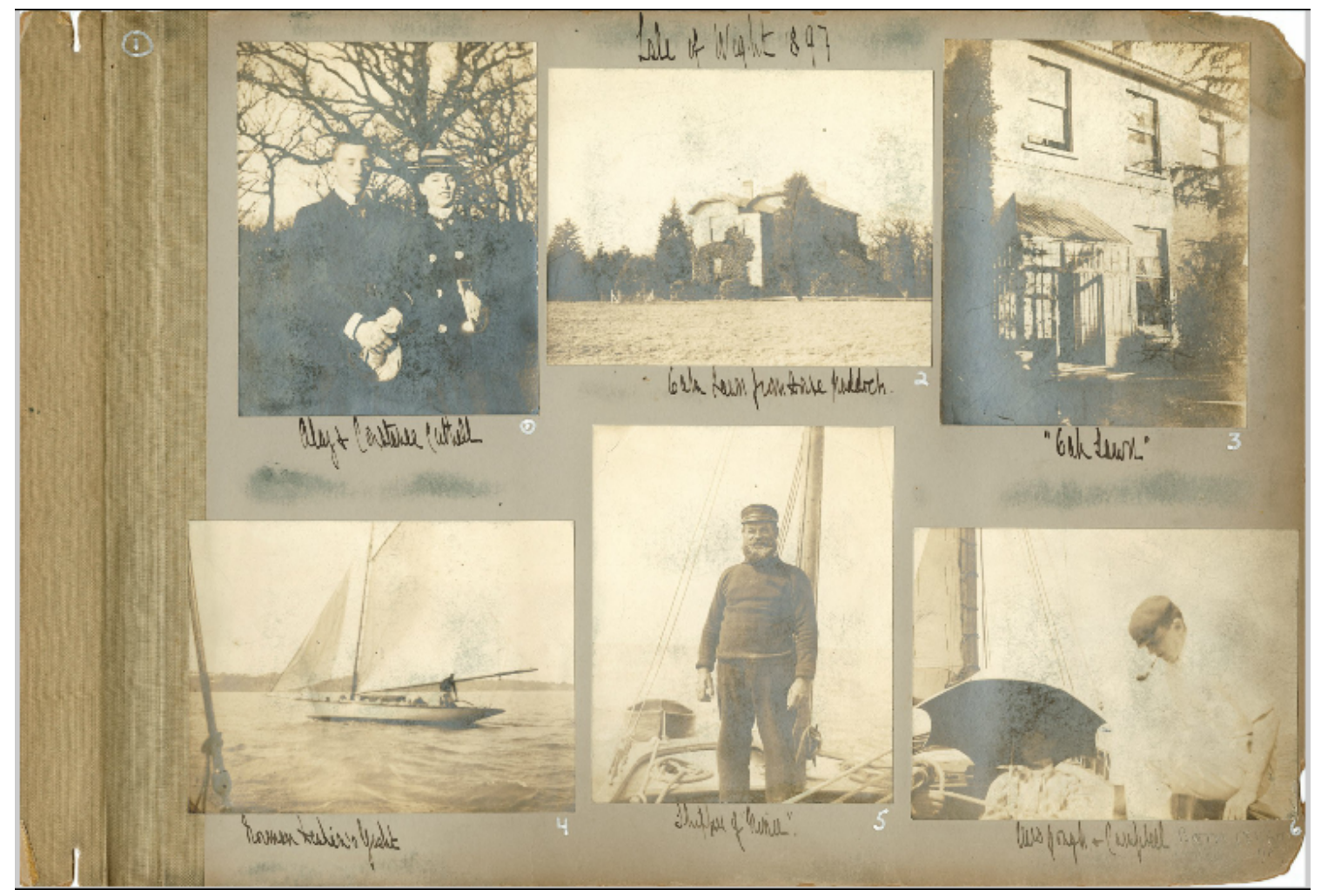

“Marjorie Howard-Futcher Album, Page 1," album page: 27.3 x 44.5 cm, McGill University Library, Osler Library of Medical History, http://digital.library.mcgill.ca/futcher/collection.php 


\section{Illustration 8:}

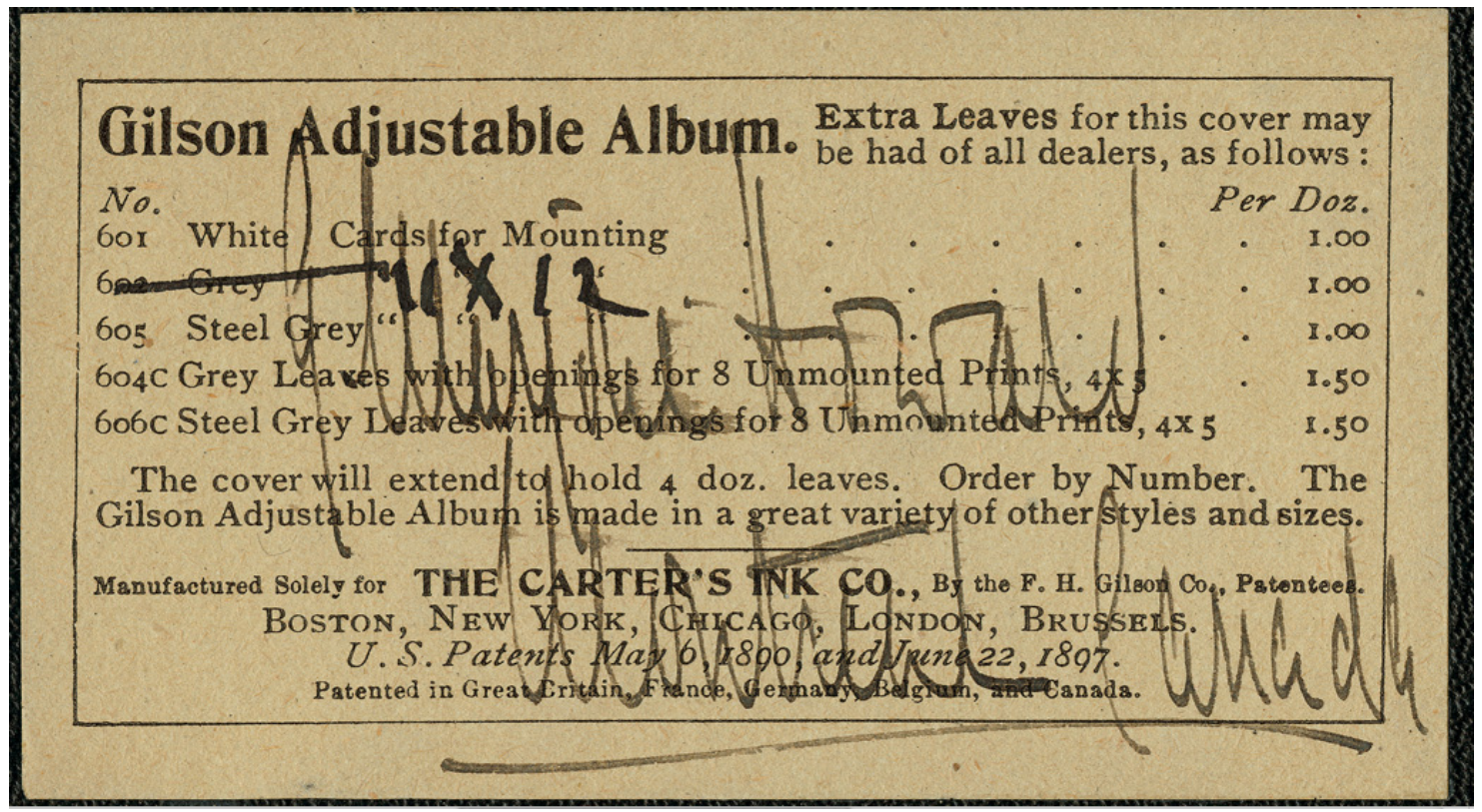

"Marjorie Howard-Futcher Album, Back cover, close-up," album page: 27.3 x $44.5 \mathrm{~cm}$, maker's mark: approx. 5 x $7 \mathrm{~cm}$,

McGill University Library, Osler Library of Medical History, http://digital.library.mcgill.ca/futcher/collection.php 


\section{Illustration 9:}

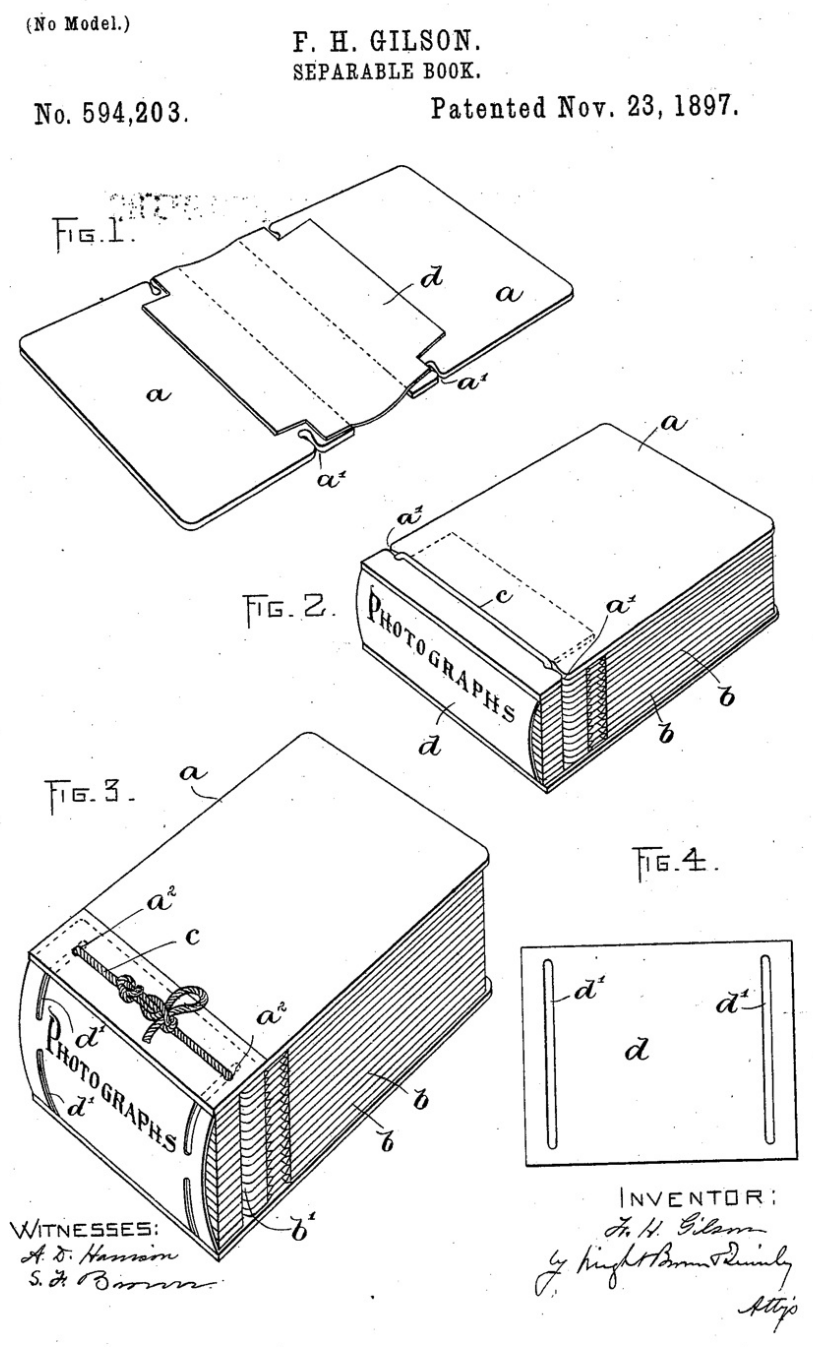

Franklin H. Gilson. 1897. Separable Book. U.S. Patent 594,203, filed February 15, 1897 , issued November 23, 1897, 1. Source: United States Patent and Trademark Office Website, URL:

http://patimg1.uspto.gov/.piw?docid=00594203\&PageNum=1\&IDKey=918A6895A871 \&HomeUrl=http://patft.uspto.gov/netacgi/nph-

Parser?Sect $2=\mathrm{PTO} 1 \% 2526 \mathrm{Sect} 2=\mathrm{HITOFF} \% 2526 \mathrm{p}=1 \% 2526 \mathrm{u}=/$ netahtml $/ \mathrm{PTO} / \mathrm{search}-$ bool.html $\% 2526 \mathrm{r}=1 \% 2526 \mathrm{f}=\mathrm{G} \% 25261=50 \% 2526 \mathrm{~d}=\mathrm{PALL} \% 2526 \mathrm{~S} 1=0594203 . \mathrm{PN} . \% 252$ $6 \mathrm{OS}=\mathrm{PN} / 594203 \% 2526 \mathrm{RS}=\mathrm{PN} / 594203$ 


\section{Index Book}

The inscribed names and occupations and the four series of numbers that appear in the index book pages require further investigation in order to understand their intended purposes. To begin with, the purposes of the numbers that are labeled "Left Side Numbers" and "Right Side Numbers" in the annotated illustration of the index book (ill. 5; pg. 22) are uncertain. They are on the same line as the names so they must relate to the individual or to the photograph of that individual. They are not running lists of numbers, so they must not correspond to another object. The repetition of numbers suggests that they demark a specific amount of something that is, unfortunately, not indicated. On page "A" of the index book (ill. 10; pg. 36) on the first line next to the name Arthur Prince, the "Left Side Number" is ' 6 ' and there happen to be six portraits of Prince Arthur on album page \#33 (see ill. 1; pg 16). This could be an indicator of the purpose of this series of numbers, but it is not consistent throughout the index book and the portraits on the disbound album pages. For example, the "Left Side Number" of next entry on Page A of the index book for "Hugh Allan" is a 4. There are only two photographs of Hugh Allan, not four. Perhaps this number could be the total number of the portraits on the album pages and the loose photographs in the now lost envelope. This is merely a hypothesis, which could only be verified if and when the lost envelope is found.

The series of numbers, which are labeled, "Portrait Sequence Numbers" have been partially decoded. The characteristics of this series differ from the other two series. They are not in numerical order but increase throughout the index book, and most importantly they do not repeat. This suggests that they link the name of the individual to something else. The inscriptions labeled "Tentative Locator Inscriptions" also imply that 
they correspond to another component that is not identified because they too are not repeated. The hypothesis that grew out of the "Portrait Sequence Numbers" and "Tentative Locator Inscriptions" is described at length in the section titled, "Relationship between the Album Pages and Index Book" (pg. 41) in this chapter. 


\section{Illustration 10:}

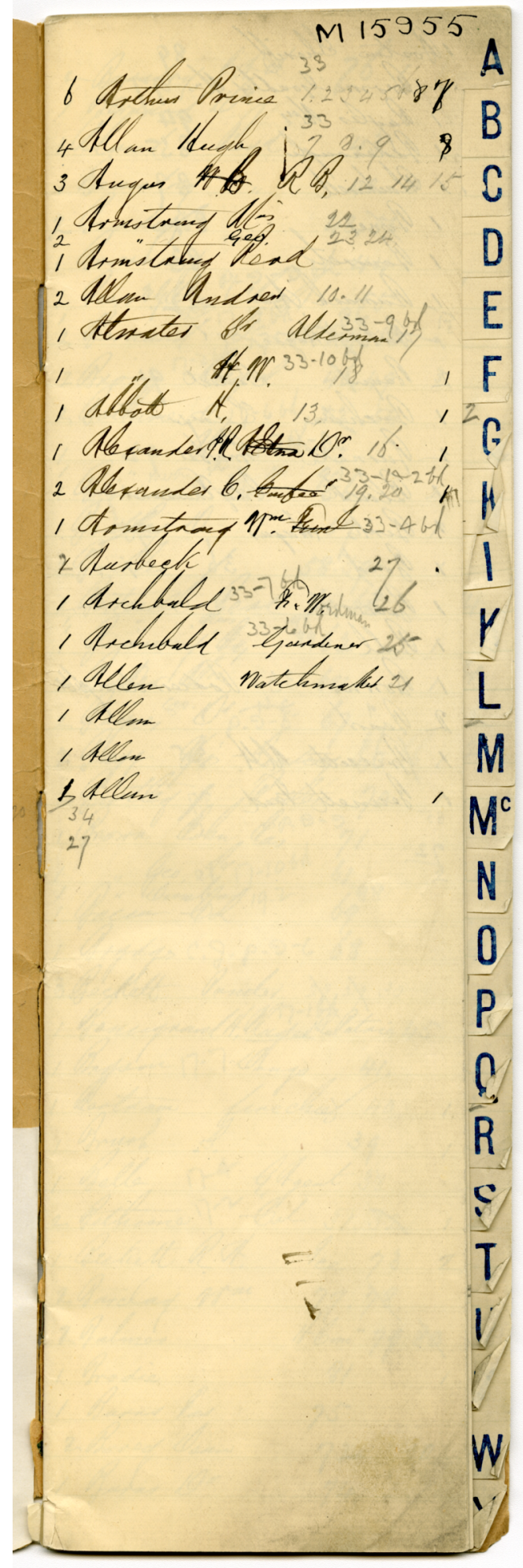

"Index Book, Page A," lined paper page, 10 x $31 \mathrm{~cm}$, McCord Museum Collection, M15955. 


\section{Related Documents}

In addition to the disbound album pages and the index book, there are four other documents in the form of folded sheets of paper that have lists of numbers and names. The numbers are made up of what have been labeled "Lead Numbers", which are five digits, and "Following Numbers", which are mostly three digits. The way in which the three digit numbers are placed below the last three digits of the five digit "Lead" numbers suggests that the first two digits of the "Lead Numbers" are the same first two digits in the list of "Following Numbers".

Assuming that all the numbers are intended to be five digits, they are characteristic of negative numbers used by the James Inglis Studio. Negative numbers are the unique numbers that a commercial studio photographer gave to each negative and resulting positive that was taken in the studio. The McCord Museum has two albums, which are referred to as "Picture Books" by the staff, but are also known as "Day Books", that were once used in the James Inglis Studio. ${ }^{35}$ These books are large leather-bound ledgers, with thin paper pages. A contact print from every negative that was made in the studio was printed, trimmed, and pasted onto the pages. Each negative was assigned a number, in the case of James Inglis' studio a five-digit number, which was written in ink below the photograph on the page. The two "Picture Books" from the James Inglis Studio

\footnotetext{
${ }^{35}$ These two "Picture Books" share the same acquisition number at the McCord Museum that is M6591. They too were transferred from the McGill University Library. John Horn donated them to McGill University. This is indicated by a handwritten note in the front of one of the albums that is dated November 1916 and signed by John Horn. No further information on Horn has been uncovered as of yet. Horn also encourages that the portraits be cut out of the album pages by any future viewer if they found a portrait of themselves or someone they knew for a fee of 25 cents per photograph to benefit the library. This is indicative of a very different consideration of photographic albums that a photographic historian has today. A good example of this can be seen in Appendix IV, where a corresponding photograph to the negative number 40841 cannot be identified because it has been cut out of the Picture Book.
} 
have negative numbers that range from 39570 to 41852 and 64874 to 67079 . The negative numbers on the related documents range from 29412 to 39522 across the four papers.

Five-digit negative numbers can be found inscribed in some of the photographs on the disbound album pages. They were inscribed with ink into the negative so when the photograph was printed the negative number is embedded in the image. In these cases the negative number is white and is normally found in the bottom corner of the portrait. The five-digit numbers on the four documents seem to partially decode the negative numbers inscribed directly into some of the photographs on the album pages. Also, many of the names on the related documents are also found in the index book. The sporadic checkmarks next to some of the numbers and names could indicate that this is the case. This will be explored in the following section, "Relationship between the Album Pages and Negative Number Documents".

The typed letters, which are that are on the verso of two of the related documents, add to the complexity of this group of objects. The way in which the lists and names are written on the back of these letter suggests that the letters were used as scrap paper. The content of the letters does not have an obvious link to the material. Both letters do, however, mention the board of governors of the Montreal General Hospital, which may provide insight into who might have wrote the list of negative numbers and names. According to Christopher Lyons, the current Liaison Librarian at McGill University's Osler Library of the History of Medicine, these types of letters were a fairly standard solicitation for support of a job. Lyons explained that such letters were not personalized because they were printed and sent out en masse, in this case, to the Board of Governors 
at the Montreal General Hospital. ${ }^{36}$ An exploration into the Board of Governors of the Montreal General Hospital in 1890, the year that both letters were sent, would possibly aid in uncovering the author of the negative numbers list, provided they were written by the recipient of the letters. Unfortunately, according to an article from November of 1891 in The Canada Medical Record, "The Montreal General Hospital is a democratic institution and depends for its success on the good opinion of more than three hundred governors, ${ }^{, 37}$ and finding the recipient of these letters would be difficult to determine and this research is beyond the scope of this thesis.

\section{Provenance Notes}

The two accompanying provenance notes provide insight into the institutional history of this group of objects because they document where the objects came from and how long they have been in the McCord Museum. This being said, however, there are still gaps in this history. The note from McGill University Librarian, Dr. Gerhard Lomer, does indicate what the transferal consisted of and that the material was in the university's library. While helpful, there are still some unresolved questions about the acquisition's provenance. The envelope of unmounted photographs is currently unaccounted for in the McCord Museum's collection. This could be for a number of reasons - it could have become mixed in with another group of objects in the collection or perhaps has been misplaced or inadvertently lost. Also, the four related documents with the negative numbers and names are not included in Lomer's note. It seems unlikely that an employee of the museum wrote these lists since they are written on the back of two typed letters.

\footnotetext{
${ }^{36}$ Christopher Lyons, e-mail to author, June $12^{\text {th }}, 2012$

37 "Montreal General Hospital," The Canada Medical Record (Montreal: J. Lovell \& Son, November 1891) 333
} 
This would be an unlikely place for a museum employee to record his or her research. Perhaps, given that they have fold lines, it is possible that they were folded up and placed inside the index book when it was transferred from the university library to the museum, and thereby not noticed. Also, the provenance before the McGill University Library acquired the objects is unknown. Research into the transferal of these objects in the McGill University Archives has been conducted, but as of yet, no library record has been found. Presumably the record of the original acquisition and its later transfer would provide more information about how the objects came to McGill University and the original owner.

The second typed provenance note raises questions as well. In the note it states that "p. 16" is missing. The album page with the "Album Page Identity Number" 16 is included in the 39 album pages. If "p.16" is missing, it is not an album page. The note has, however, been confirmed as a direct transcription from the McCord Museum's own accession books. Although Lomer's note states that the group of objects was transferred on March $1^{\text {st }}, 1922$, the second note says that they were received on June $3^{\text {rd }}, 1932$. While it initially appeared that the person who typed the note had incorrectly typed the date (meaning to type June $3^{\text {rd }}, 1922$ ), a consultation with the McCord Museum's accession books confirms that the date of June $3^{\text {rd }}, 1932$ is correct. Nora Hague, the current archivist and Hélène Samson, the current curator of the Notman Photographic Archive at the McCord Museum, advised that it is likely that the objects were moved from the university to the museum in 1922, but were not registered in the museum's accession book until 1932. This backlog is probable because the David Ross McCord Historical 
Museum was only inaugurated in 1921 and a large volume of material was coming into the small, newly established museum.

\section{Intellectual Organization}

\section{Relationship between the Album Pages and Index Book}

As discussed in the previous section, there are numbers inscribed in pencil next to the surnames in the index book, labeled "Portrait Sequence Numbers". The characteristics of these numbers led to a hypothesis about the relation between the index book and the photographs in the album pages: that these numbers correspond to the order that the photographs appear on the album pages. This relationship was not recognized or understood before this thesis.

To test this hypothesis, as many of the corresponding portraits possible needed to be identified. Additional inscriptions, which appear intermittently throughout the index book, aided this process. These inscriptions, which have been designated "Tentative Locator Inscriptions" (see ill. 5; pg. 22), locate portraits on the album pages by referencing the numbers, written in pencil, on the top right of each album page; these are designated as "Album Page Identity Numbers" (see ill. 1, pg. 16). A good example of these helpful, intermittent inscriptions is from the D page of the index book (see ill. 5; pg. 22). Next to the ink inscription "Drummond Geo" is written, "16-4". This indicates that the portrait of George Drummond, is found on the Album Page \#16 and it is the fourth photograph on the recto of the page (see ill. 2; pg. 17). Inscriptions with "bk" written after the photograph number indicate that they are located on the "back" or verso of the album page. For example, another inscription from the D page of the index book and 
visible in the annotated illustration, (see ill. 5, pg. 22) reads, "Dods P. D., p12-3 bk" and its corresponding portrait of P.D. Dods is found as the third portrait on the verso of Album Page \#12.

The "Tentative Locator Inscriptions", which suggest previous research by an unknown individual, facilitated testing the proposed hypothesis. Beginning with these tentatively located and identified portraits, the inscribed surname (such as, for example, Drummond, George) was entered into the McCord's Museum's extensive database and the results, mostly portraits from the William Notman Studio, were cross-checked with the corresponding portrait in the album pages. Once a number of these tentatively identified portraits were positively identified by a comparison with a securely identified and dated portrait, it was confirmed that the "Tentative Locator Inscriptions" in the index book could be used as reliable reference points. This would mean that the names in the index book that both precede and follow the names with the "Tentative Locator Inscriptions" inscriptions would correspond respectively to portraits adjacent to the positively identified portrait in the album pages.

Album Page \#16 is a good example of this methodology (ill. 2; pg. 17). Album Page \#16 is one out of the three pages that holds portraits of individuals whose surname begin with the letter " $\mathrm{D}$ ". In the index book there are three names and their corresponding "Portrait Sequence Numbers" that have "Tentative Locator Inscriptions" demarking Album Page \#16. They are: the previously mentioned "Drummond Geo, 16-4, 159", "Devlin, 16-6, 161" and "Dyde, 16-7, 162". This indicates that the fourth, sixth and seventh photograph on the recto of Album Page \#16 are respectively Mr. George Drummond, Mr. Devlin and Mr. Dyde. When researched in the McCord Museum's 
database, this was confirmed. Working backwards from the fourth photograph on the recto of page 16, that of Mr. George Drummond, which is demarked number 159, the inscriptions in the index book are, "158 Denham G.”, "157 Darling Sr.” and "156 Darling Jr.". These three corresponding photographs were also positively matched to portraits of the same individuals made by the William Notman Studio in the Museum's database. This same methodology was carried forward for the remaining seventeen photographs on both the recto and verso of Album Page \#16, which have "Portrait Sequence Numbers" that begin at 156 and end with 176.

This methodology proved that the proposed hypothesis was right, with a few exceptions. The "Portrait Sequence Numbers" in the index book did not consistently follow a numerical sequence. Some numbers are missing altogether from the index book and some surnames in the index book do not have numbers next to them. While not reliable in every case, the "Portrait Sequence Numbers" did help enormously with the identification of the majority of the individual portraits.

This methodology also resulted in the re-establishment of what is thought to be the original or intended sequence of album pages. The reordering of the album pages is based on the hypothetical reasoning that the original order of the portraits on the individual 39 disbound album pages and the original sequence of the pages would both have been alphabetical, and that the album pages were not numbered in any way. Perhaps they were bound in a Gilson Adjustable Album, but in any case, the first owner must have understood the material and the order. However, at some time, this knowledge was lost, and the album pages were re-ordered into a seemingly arbitrary order and were then numbered in pencil in the upper left corner of each card, referred to in this thesis as the 
"Album Page Identity Numbers". At some other time - this could have been earlier or later but independent of the person who numbered the pages - someone else realized that the original order was intended to be alphabetical, and he or she annotated the entries in the Index book with the "Portrait Sequence Numbers" and the "Tentative Locator Inscriptions". The author of this thesis has reestablished original order of the album pages, because it is clear, through the numerous identifications of the majority of the portraits that the pages were intended to be in alphabetical order. Appendix I (pg. 92) demonstrates the order that the author found the pages in upon starting research and the revised order that follows the "Portrait Sequence Numbers" hypothesis.

To organize the identifications and visualize the arrangement of the "Portrait Sequence Numbers" within the album pages, a catalogue was created. This catalogue appears as Appendix II (pg. 94) of this thesis. Developing a logical catalogue structure for the identifications of the 579 photographs in the album pages was essential to transforming this group of objects into a practical and authoritative research tool. To maintain consistency in the methodology, a controlled vocabulary was employed. Identifying men and women by matching them with portraits taken by another photographer, usually Notman, either earlier or later, was difficult at points. The controlled vocabulary, used in the sixth column from the left titled, "Identifying Match" in Appendix II (pg. 94), is an expression of the degree of certainty or uncertainty.

The identifying matches, which are certain, are denoted "D" for "Definite". To qualify as a definite match, the portrait in the album page and at least one other photograph of the sitter must exhibit exact physical characteristics. Similarly positioned portraits and distinct physical features often aided this identification. An example of a 
definite match is the corresponding photograph to the index book inscription, "Dods P. D., p12-3 bk, 148" (see ill. 5; pg. 22). This photograph can be found on the album page marked number 12, and it is the third photograph on the verso. When "P. D. Dods" was searched in the McCord Museum's database, one of the resulting photographs by the Notman studio was the image labeled "I-6656.1"38 (ill. 11; pg. 47). When compared with the photograph in the album page (ill. 12; pg. 48), the resemblance is clear. Both men in the portraits have similar length and style of hair, sideburns and facial features. This constitutes a definite match.

The identifying matches that have some but not all of these matching characteristics, were denoted "P" for "Probable". Probable matches were often influenced by the numbering system. If the "Portrait Sequence Numbers" indicates that a specific photograph is a certain individual and the only identifying match photograph is similar to the portrait in the album page, it was labeled a probable match. An example of a probably match is the photograph that corresponds to the index book inscription "137, Date Plumber". According to the proposed hypothesis and methodology, since the "Portrait Sequence Number" before, number 136 is definitely matched to the first portrait on the recto of Album Page \#12, the number 137 indicates that the second photograph on Album Page \#12 is Mr. Date (see Appendix II; pg 88). The second portrait on Album Page \#12's recto (ill. 13; pg. 49) shows a man who has slightly different facial hair from the William Notman Studio portrait of Henry H. Date (ill. 14; pg. 50). The man's build, facial structure and age in both photographs seem quite close. This match qualifies as a probable match because the man in the Notman portrait is wearing a hat, which hides his

\footnotetext{
${ }^{38}$ This label, "I-6656.1" is an example of William Notman's numbering system used in his portrait studio. For more about Notman's numbering system see: http://www.rootsweb.ancestry.com/ qcmtlw/notman.htm
} 
hair style and also because the portrait is full length, which lessens the visual detail of facial features that are useful for comparison.

Lastly, there were some portraits that could not be identified. This happened for a variety of reasons, either the individual's name did not exist in the McCord Museum's database or the portrait from the album pages did not have enough distinguishing features to make it a positive match. Also, deciphering the handwriting in the index book proved challenging for some inscriptions, and some of the names were impossible to determine. These portraits, which could not be definitely or probably matched, are demarked by an "[Unidentified Man]" or "[Unidentified Woman]" inscription in Appendix II (pg. 94). 


\section{Illustration 11:}

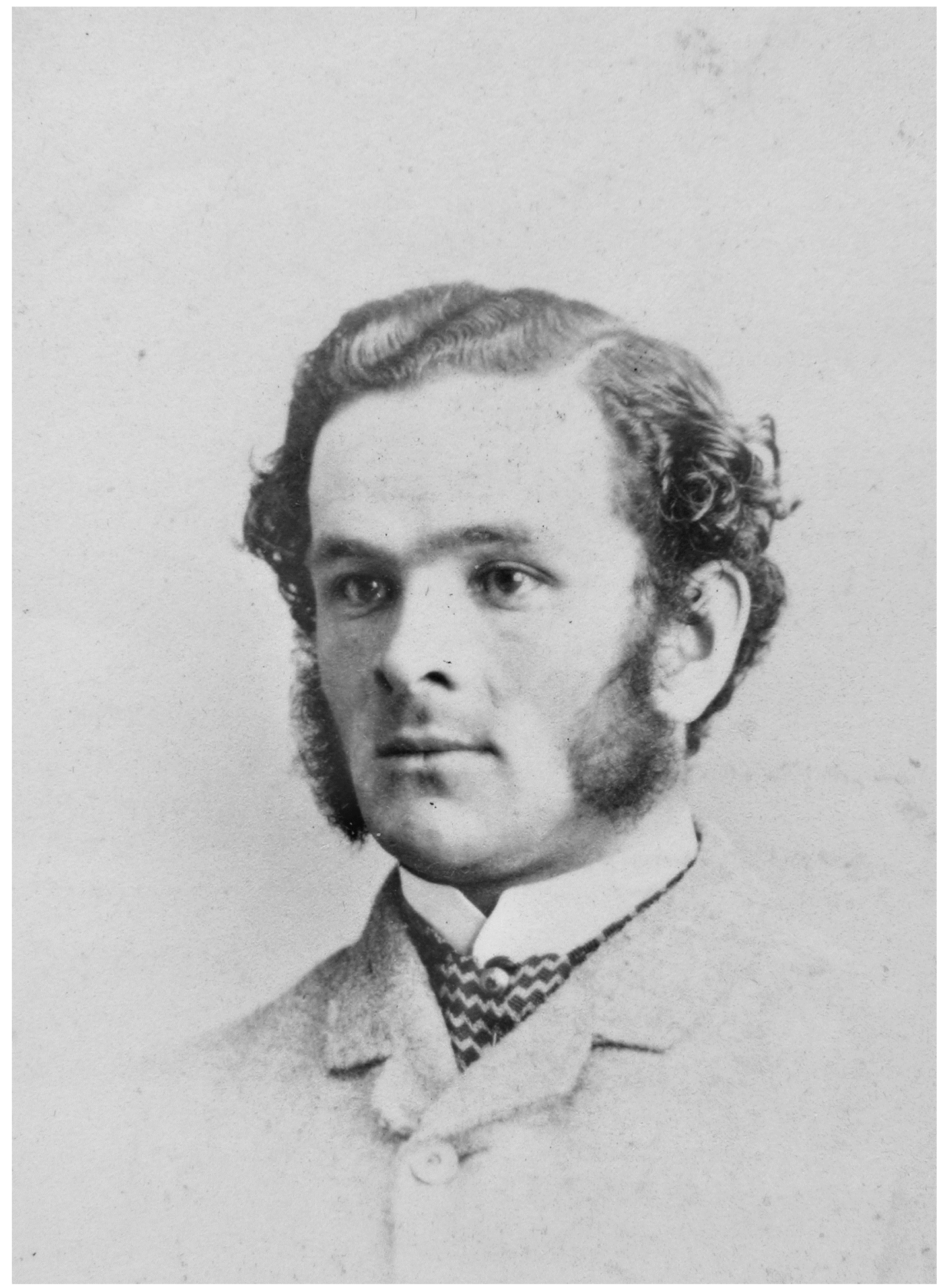

“P. D. Dods, Montreal, QC, 1863” by William Notman, albumen Print, 8.5 x $5.6 \mathrm{~cm}$ McCord Museum Collection, I-6656.1. 


\section{Illustration 12:}

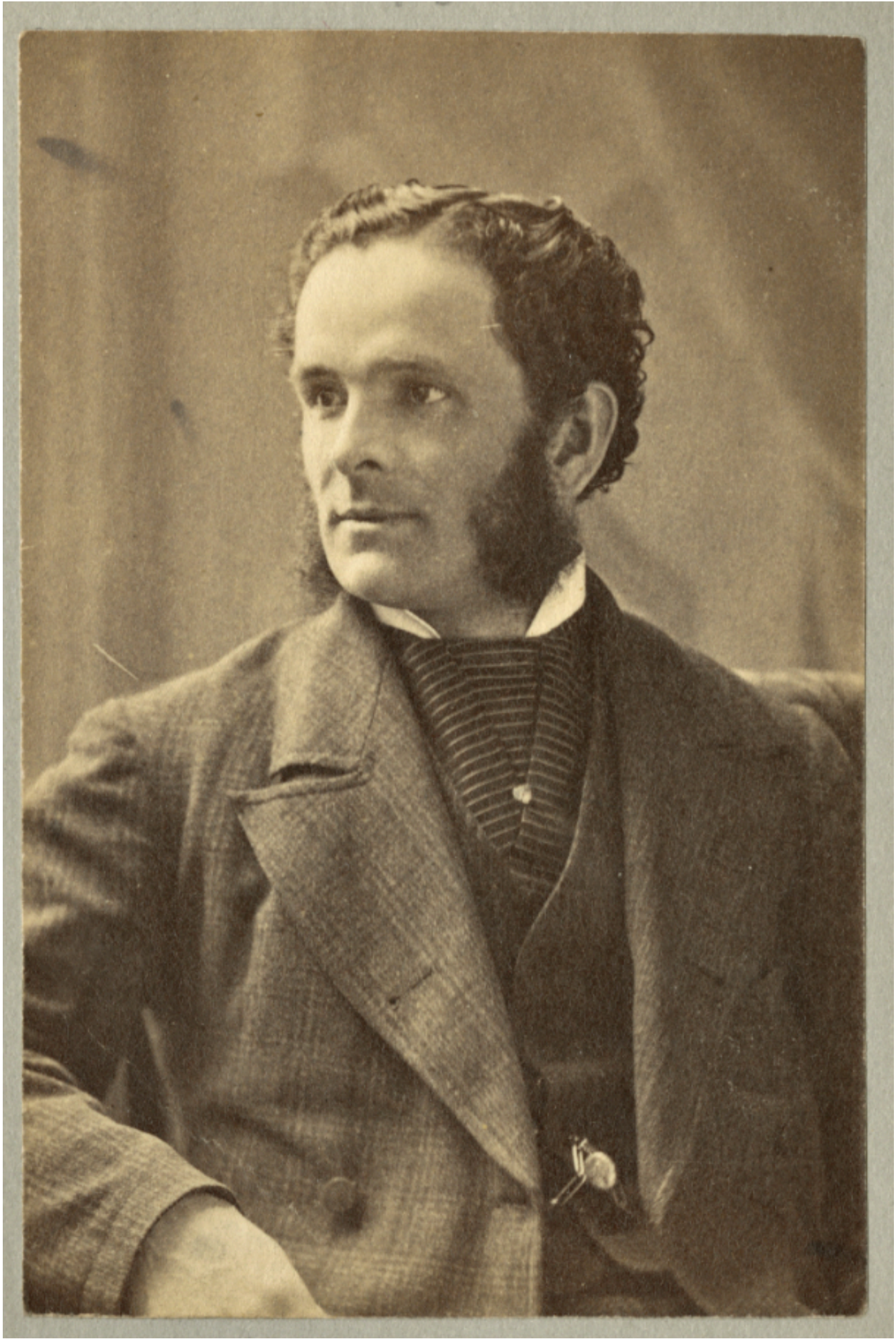

“P.D. Dods, Album Page \#12, Image 3," albumen Print, 5 x 7 cm, McCord Museum Collection, M15955. 


\section{Illustration 13:}

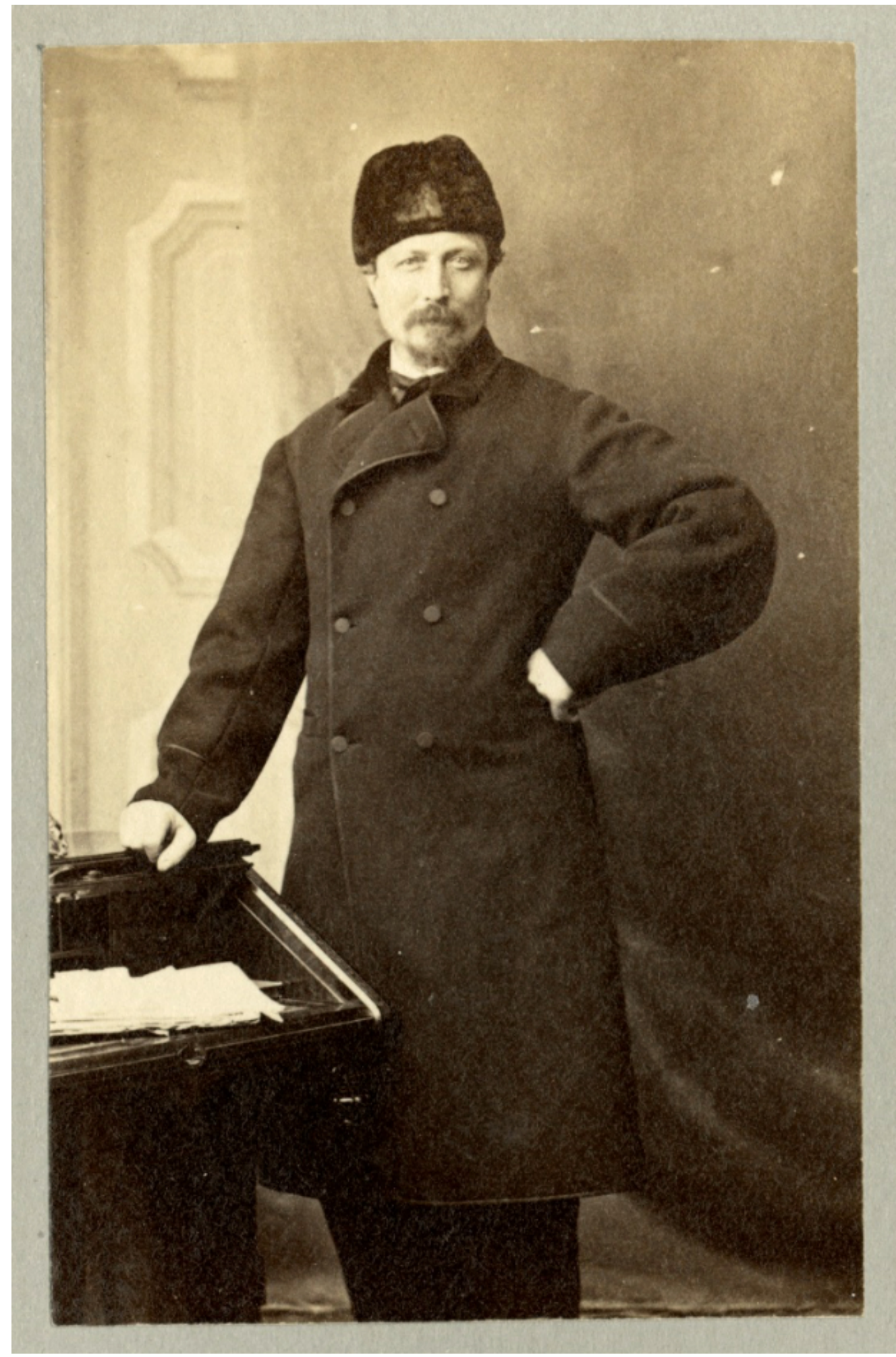

"Mr. Date, Album Page \#12, Image 2," albumen print, 5 x 7 cm, McCord Museum Collection, M15955. 


\section{Illustration 14:}

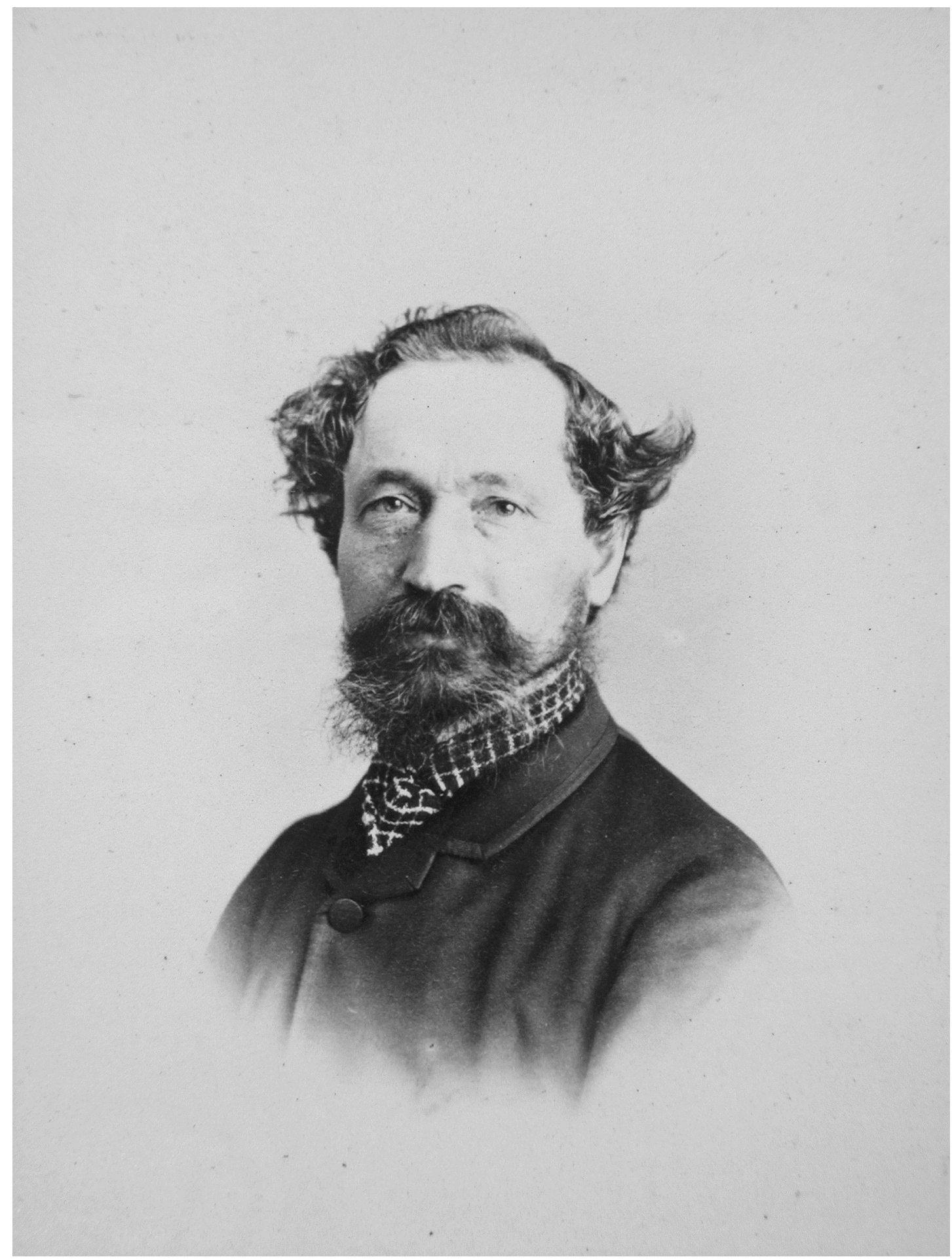

“Henry H. Date, Montreal, QC, 1863" by William Notman, albumen print, 8.5 x $5.6 \mathrm{~cm}$ McCord Museum Collection, I-6988.1. 


\section{Relationship between the}

\section{Album Pages and Related Documents}

As previously discussed in "Related Documents" section of this chapter, the lists of negative numbers and names on the four related documents reference five-digit negative numbers that are inscribed directly into some of the photographs on the album pages. The lists of negative numbers and names from the related documents have been transcribed in Appendix III (pg. 135). In Appendix IV (pg. 140) the negative numbers that have been inscribed into the negatives of the photographs on the album pages have been cross-referenced with these lists of negative numbers.

Unfortunately, only one definite match has been confirmed thus far. The first photograph on the second, lower row (image 6) of the recto of Album Page \#22, (ill. 15; pg. 53) has been identified using the "Portrait Sequence Number" and the corresponding name as "Mrs. Sharpley, 22-6, 517". However, this match has not been confirmed by cross-referencing it with another photograph - because no female portraits by the name Sharpley could be found in the McCord Museum's database. It has been entered into the catalogue because of its "Tentative Locator Inscription", "22-6" and also because it is the only portrait of a woman on Album Page \#22 (see Appendix III; pg. 91). The "Portrait Sequence Numbers" 519, 520 and 521 have been definitely matched on the recto of Album Page \#22, which increases the likely-hood that the portrait, which corresponds to the "Portrait Sequence Number" 517 on the recto of Album Page \#22, is Mrs. Sharpley. In her portrait, Mrs. Sharpley is seated in front of a painted backdrop, holding a parasol. At the tip of the parasol, on the floor of the studio, the number " 34358 " is inscribed into the negative. This number also appears on the Related Document labeled \#2. The first 
inscription in the third column, defined by the fold lines in the paper, reads, "34358 Mrs. Sharpley $\sqrt{ } "$.

This match confirms that the related documents do in fact relate to the album pages. Being the only definite match, however, suggests that the related documents were not made exclusively for the album pages and the index book. Since the majority of the negative numbers are not represented in the album page's photographs, nor can they be found in the two James Inglis Studio "Picture Books" that the McCord Museum has in their collection, the author of these lists must have had access to another object(s) that carried the range negative numbers found on the related documents (numbers 29412 to 39522). This object could be another "Picture Book" or ledger that belonged to the James Inglis Studio, or perhaps a large collection of carte-de-visites and cabinet cards, that matched the portraits and provided the negative numbers. The original source for the lists of negative numbers and names on the four related documents is unknown. Nevertheless, the relationship between the four related documents and the album pages has revealed how these objects can be used together and thus augment the entire group of objects' use as a research tool if in the future this additional information is unearthed. 


\section{Illustration 15:}

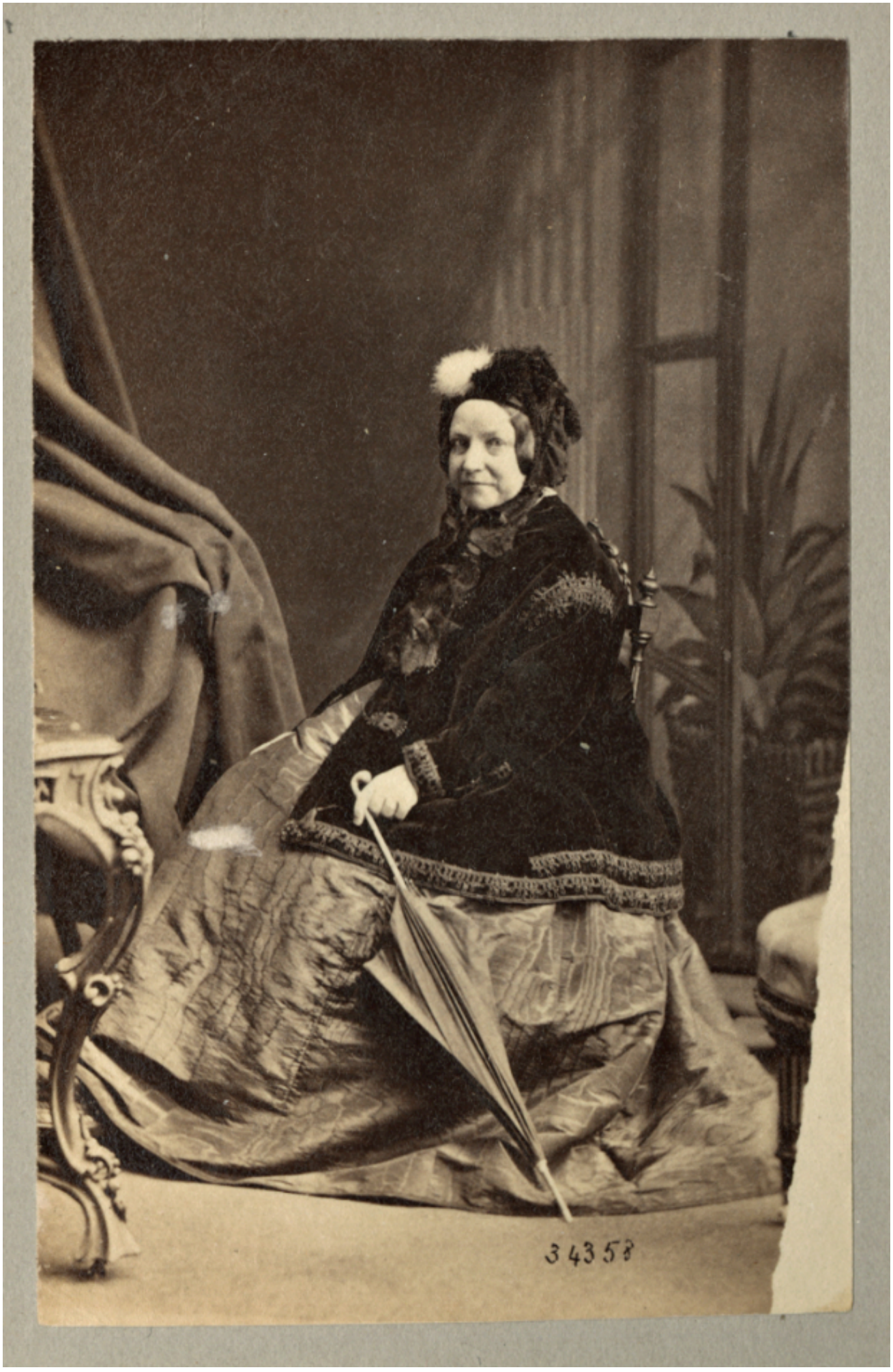

"Mrs. Sharpley, Album Page \#22, Image 6," albumen print. 5 x $7 \mathrm{~cm}$ McCord Museum Collection, M15955. 


\section{Relationship between the \\ Index Book and Related Documents}

The relationship between these two components of the group of objects is not as clear as the connections between the disbound album pages and the index book. The index book and the related documents have the album pages in common, but do they relate to one another? A close inspection of the objects revealed that the "Portrait Sequence Numbers" and the "Tentative Locator Inscriptions" in the index book, used to identify the photographs, appear to be written in the same hand as the lists of numbers and names on the negative number documents. This suggests that the same author added the "Portrait Sequence Numbers" and the "Tentative Locator Inscriptions" to the index book in or after February 1890 because the dates of the typed letters that appear on the back of the related documents are in February of 1890. The dating is discussed in greater detail in the following sections of this chapter. 


\section{Attribution of Photographs}

A large number of the portraits in the disbound album pages can now be attributed to his studio, and this section will outline the information that has been gathered about James Inglis' studio in Montreal from this group of objects. Noteworthy identifying matches that link the portraits to the studio will be described. Also, the negative numbers in the related documents can be linked to the number system used in the James Inglis Studio. This will be described in conjunction with the other two James Inglis "Picture Books" in the McCord Museum's collection. This section is intended to facilitate research into the James Inglis Studio numbering system, which is extremely useful to researchers. Understanding the numbering system of a commercial portrait studio can aid future researchers in identifying and dating carte-de-visites and cabinet cards and also provides insight into how these commercial businesses were operated in the nineteenth century.

\section{Identifying Matches Linked to the James Inglis Studio}

The identifying matches that concretely link the album pages' portraits to the James Inglis Studio are particularly significant. One of these connections is an exact match between a photograph in the album pages of Henry Morgan (1819-1893) (ill. 16; pg. 58) and the McCord Museum's photograph of Henry Morgan by James Inglis (ill. 17; pg. 59). This latter portrait is a carte-de-visite that has, on its verso, an elaborate crest with a lion and a star, and a printed credit at the top that reads, "James Inglis, Photographer, Montreal". Henry Morgan owned and operated Henry Morgan and Company, which in its time was considered "the largest store for dry goods, dresses, and 
fashion items in Montreal. ${ }^{\prime 39}$ When the portrait was taken in the 1870's, Morgan's company was booming. According to the 1871 census the company, "had 37 employees, 12 men and 25 women, and the inventoried value of its stock totaled some $\$ 640,000 .{ }^{, 40}$ The fact that Henry Morgan would have his portrait taken at the James Inglis Studio attests to the caliber and reputation of Inglis' company. ${ }^{41}$ His clientele included many of the most successful merchants in the city.

Another significant match is the portrait of Prince Arthur, Duke of Connaught and Strathearn $(1850$ - 1942) from the album page (ill. 18, pg. 59), and a reproduction based on that same portrait that was published in The Canadian Illustrated News on April 9th 1870, (ill. 19; pg. 61). The portrait was published on a full page of the magazine and titled "H. R. H. Prince Arthur, in Winter Dress. From a photograph by Inglis." ${ }^{, 2}$ This identifying match is noteworthy because it too shows the type of clientele that the James Inglis Studio was attracting and also shows that Inglis was a part of the innovative photomechanical reproduction technology that was occurring in Montreal at the time.

James Inglis certainly was an advocate for keeping abreast on the newest innovations in his industry. Composite photography, the process of cutting photographs, arranging them on photographed or painted backdrops and re-photographing the whole, was one of the latest trends that proved to be very popular and thus lucrative for both

\footnotetext{
${ }^{39}$ Hughette Filteau, Dictionary of Canadian Biography Online, "Henry Morgan”, 2000. http://www.biographi.ca/009004-119.01-e.php?\&id_nbr=6313

${ }^{40}$ Hughette Filteau, Dictionary of Canadian Biography Online, "Henry Morgan”, 2000. http://www.biographi.ca/009004-119.01-e.php?\&id_nbr=6313

${ }^{41}$ The McCord Museum Collection does not have a portrait of Henry Morgan by William Notman, only a portrait of Master Henry Morgan as an infant in 1863 (Notman Negative Number: I-6691.1), presumably this is Morgan's son. It would be unlikely that Morgan would only have his portrait taken at James Inglis Studio, but the above-mentioned portrait does attest to the type of clientele that frequented the studio.

${ }^{42}$ Library and Archives Canada, "Canadian Illustrated News: Images in the news: 1869-1883" http://www.collectionscanada.gc.ca/databases/cin/001065-119.01-

e.php?\&nl_id_nbr=1014\&brws_s=1\&\&PHPSESSID=7hilkv8vs98rjo5o2h505qk264
} 
Inglis and, especially Notman's portrait studios. Several of the portraits in the album pages can be matched to individuals that make up a composite work by James Inglis. The matches that were used in Inglis' composite work are important to note because they reveal part of his working process, his business acumen and competitive nature. The McCord Museum holds a very early composite photograph entitled Victoria Rifles, Montreal, QC, Composite by James Inglis, 1870 (ill. 20, pg. 62). The portraits of Colonel John M. Crawford, Taylor Homer, Colonel E. A. Whitehead and Capitan E. B. Greenshields have all been identified in this composite photograph. As this comparison between the portrait of Colonel John M. Crawford from the album pages (ill. 21; pg. 63) and a detail from the Victoria Rifles composite (ill. 22; pg. 64) reveals, these two photographs were made from the same negative. 


\section{Illustration 16:}

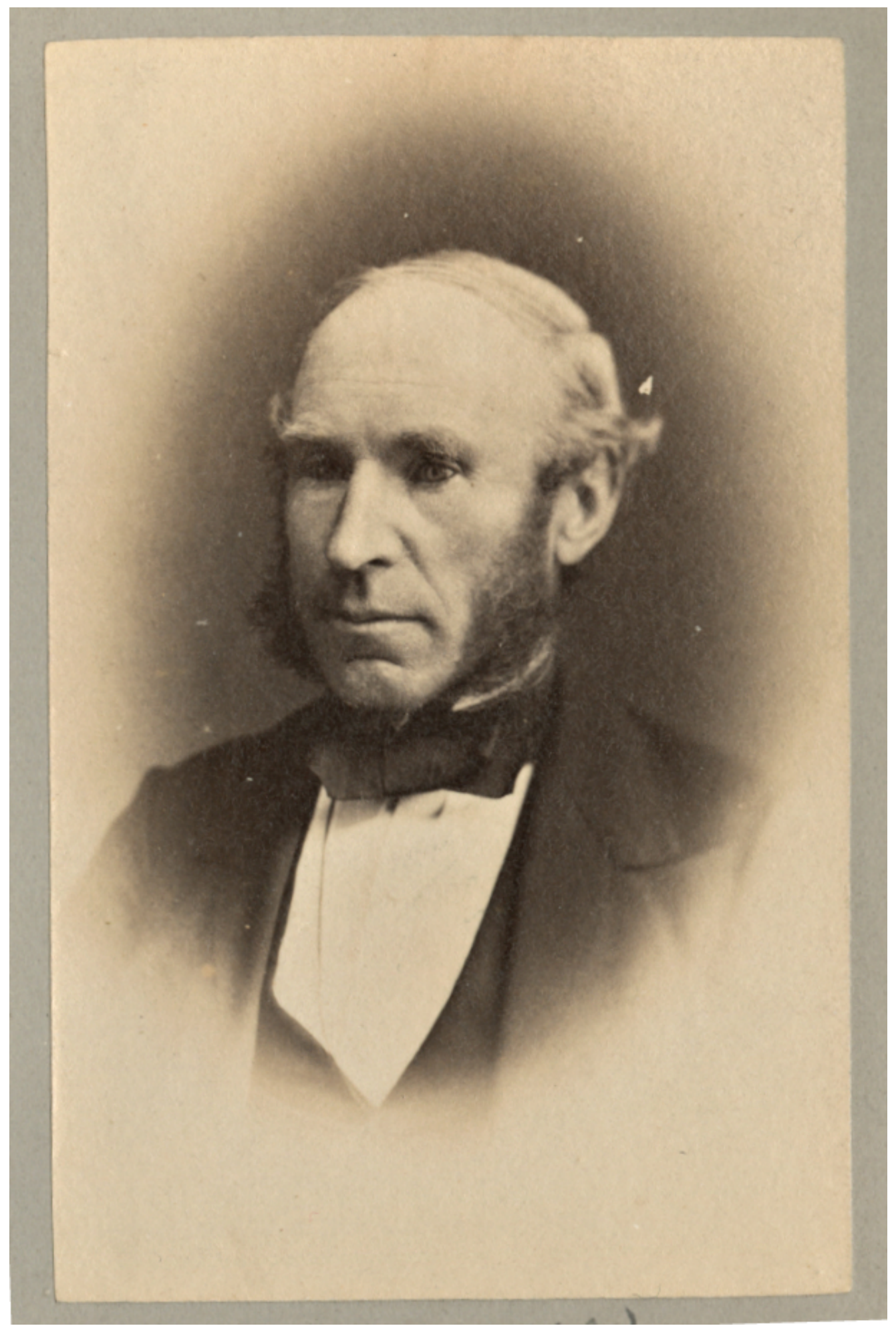

"Henry Morgan, Album Page \#20, Image 5," albumen print, 5 x $7 \mathrm{~cm}$ McCord Museum Collection, M15955. 


\section{Illustration 17:}

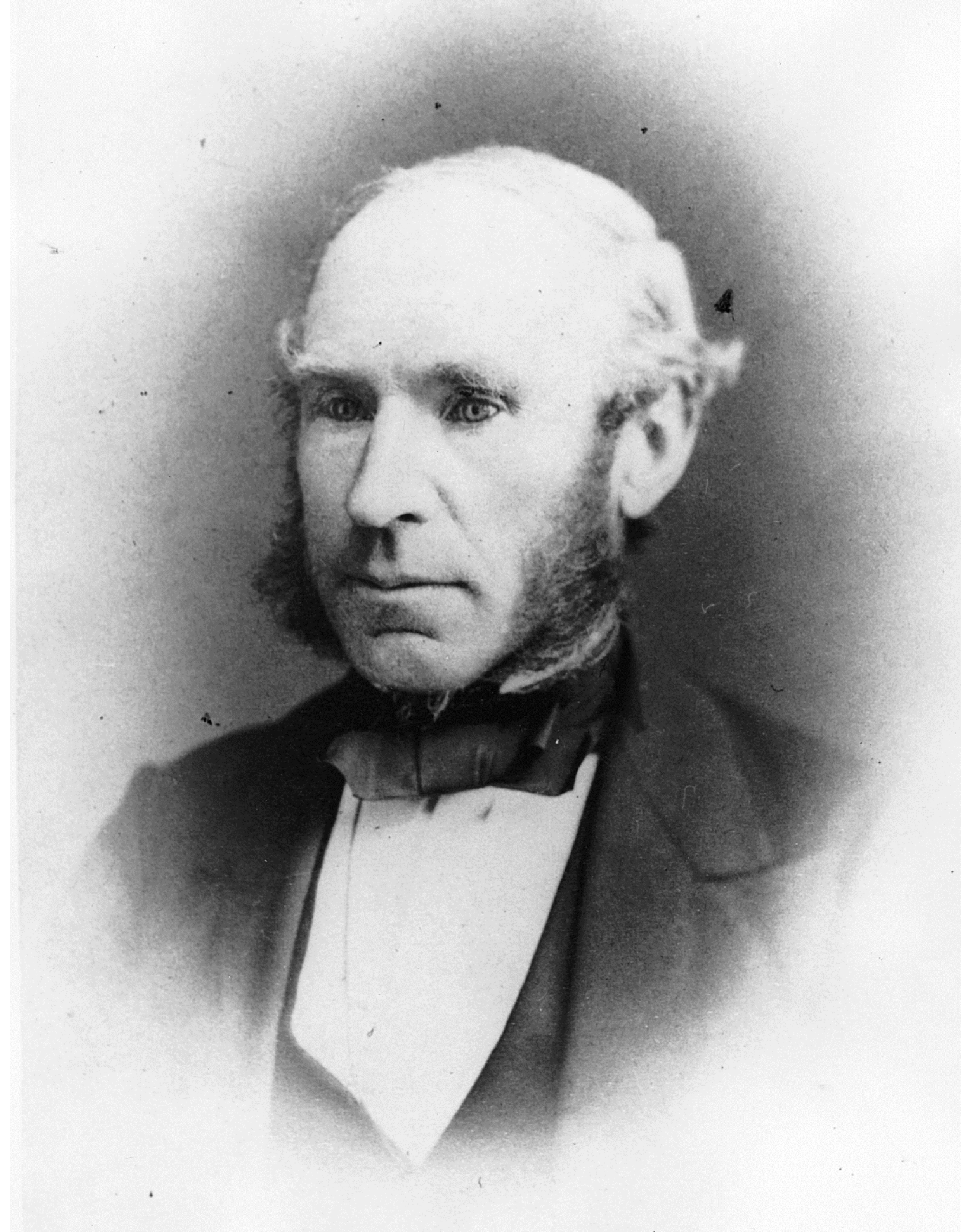

“Henry Morgan, Montreal, QC, about 1875" by James Inglis, albumen print, 5 x 8 cm, McCord Museum Collection, MP-1991.21. 


\section{Illustration 18:}

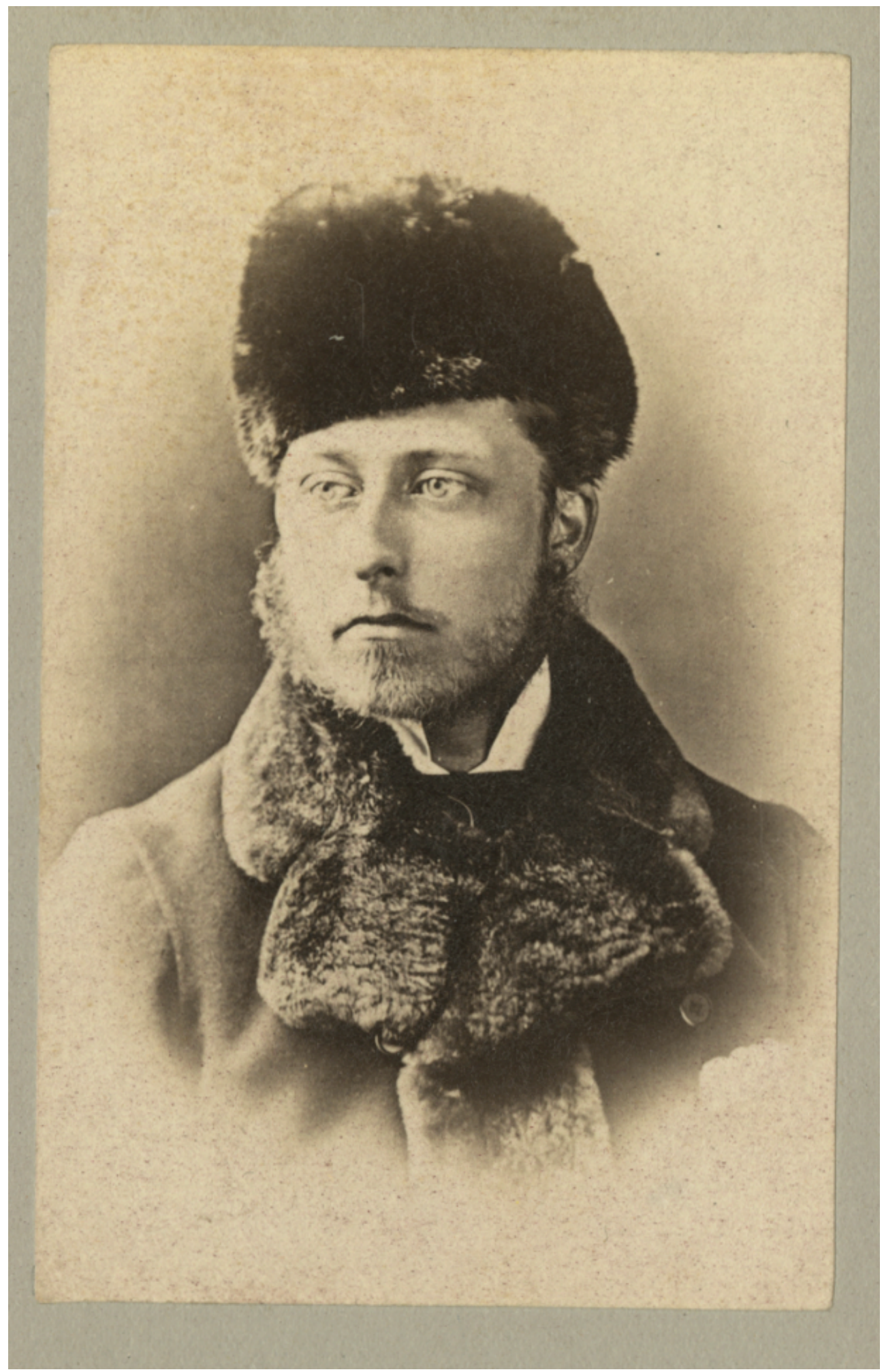

"Prince Arthur, Album Page \#33, Image 3," albumen print, 5 x $7 \mathrm{~cm}$ McCord Museum Collection, M15955. 


\section{Illustration 19:}

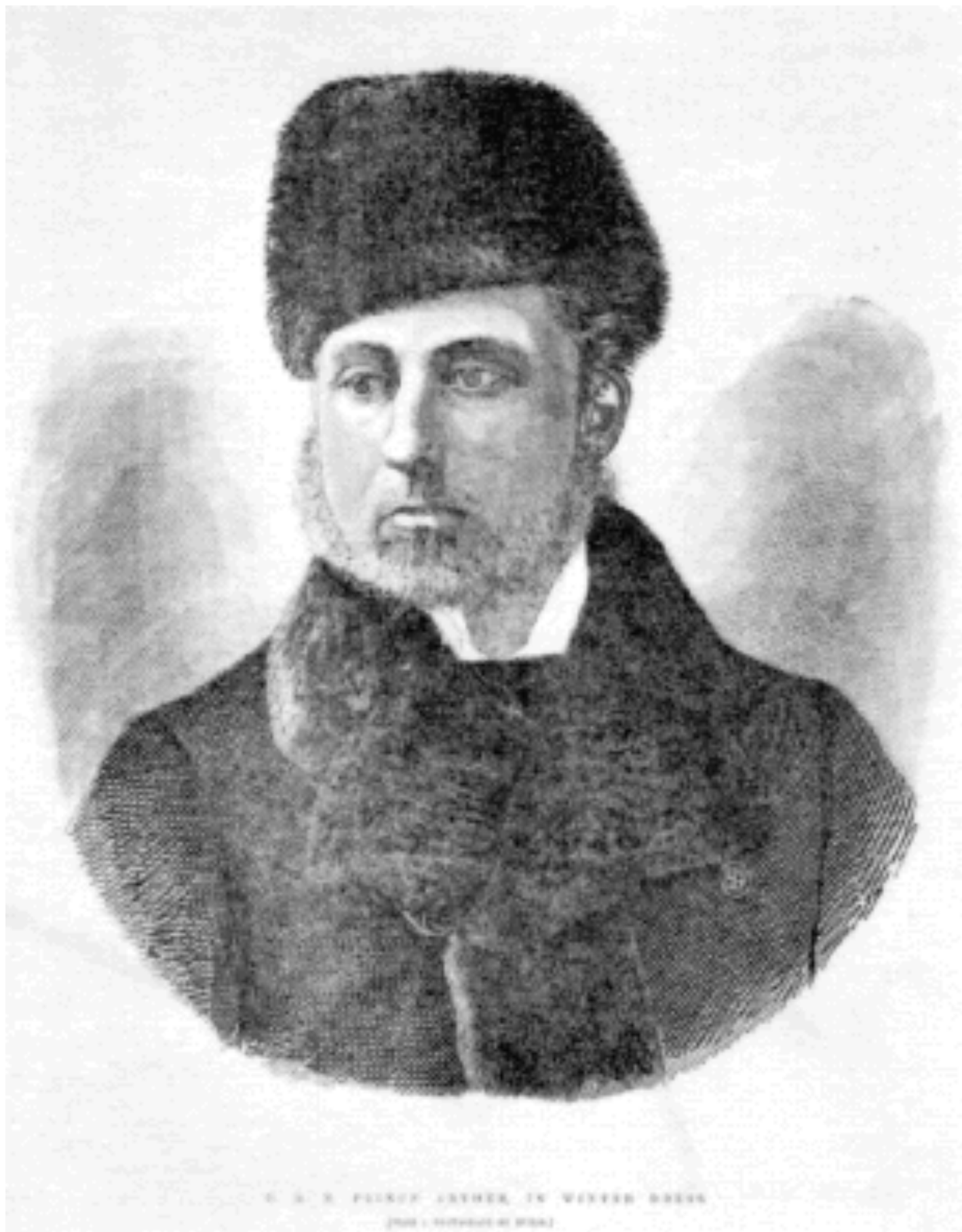

"H.R.H. Prince Arthur, in Winter Dress. Photo by Inglis" by James Inglis in Canadian Illustrated News, No. 23, p. 357, April 9th, 1870, dimensions unknown,

\section{Leggotype process}




\section{Illustration 20:}

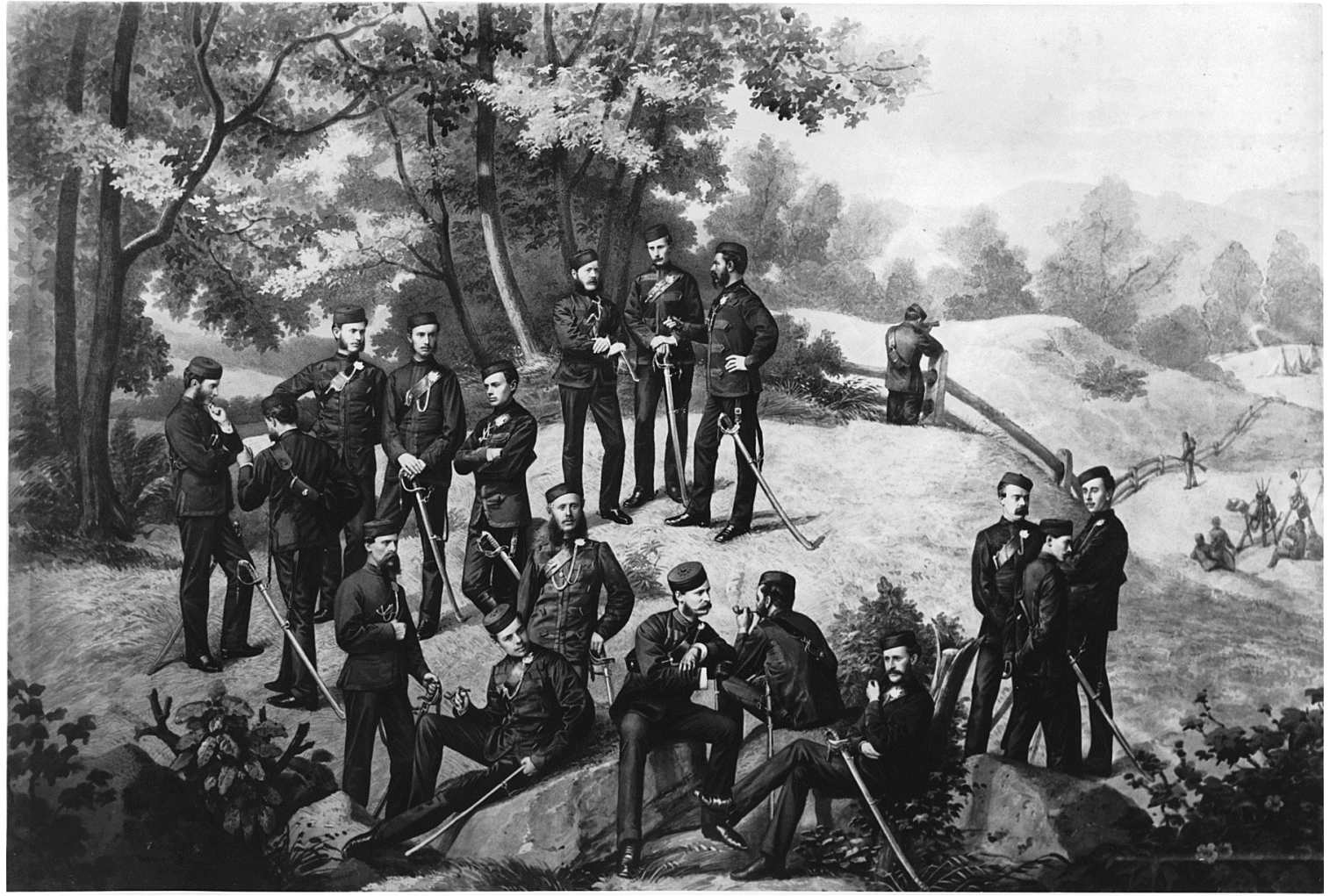

“Victoria Rifles, Montreal, QC, composite by James Inglis, 1870” by James Inglis, albumen print, 32 x $47 \mathrm{~cm}$ McCord Museum Collection, MP-1986.21. 


\section{Illustration 21:}

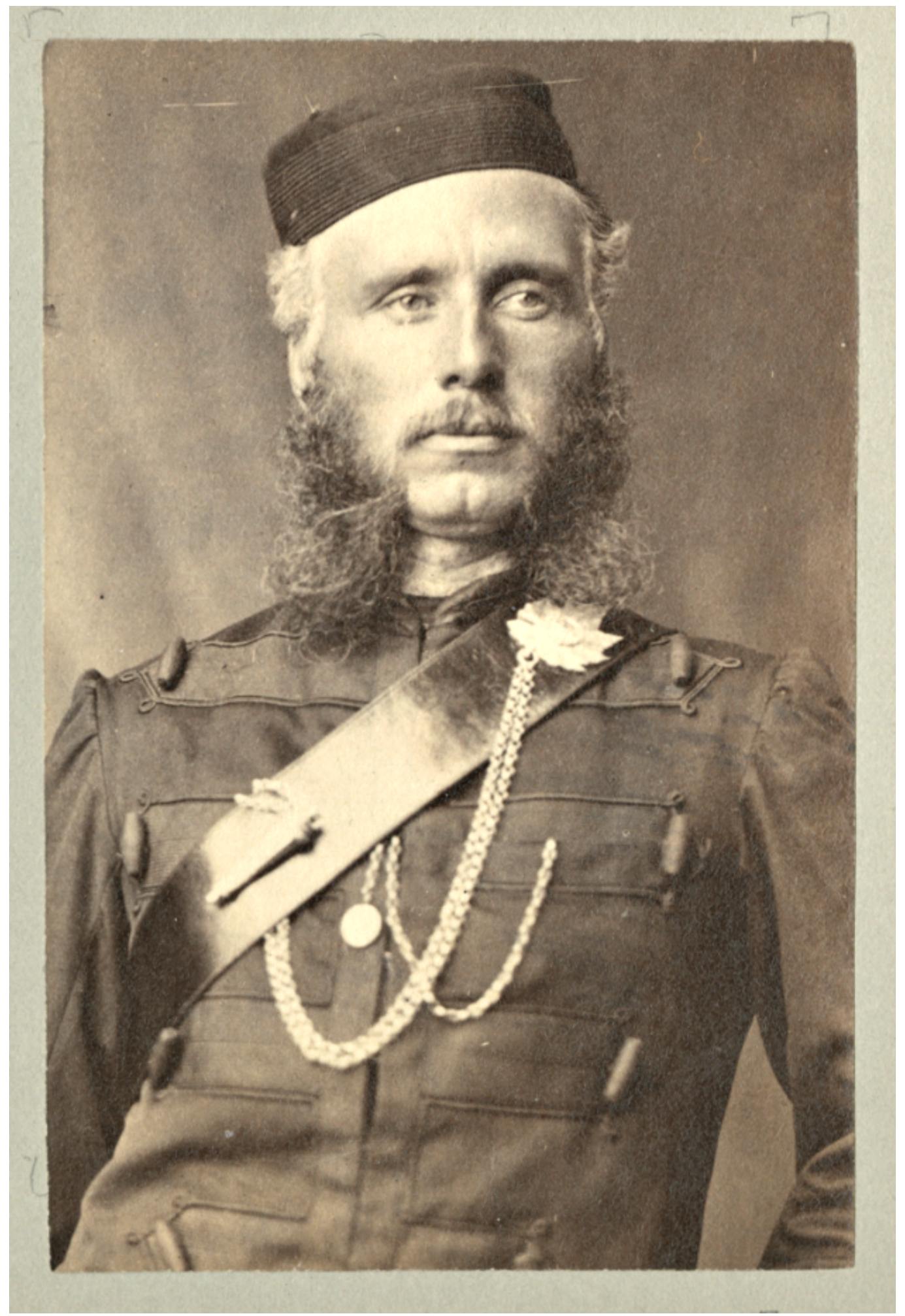

“Col Crawford, Album Page \#30, Image 10", albumen print, 5 x $7 \mathrm{~cm}$ McCord Museum Collection, M15955. 


\section{Illustration 22:}

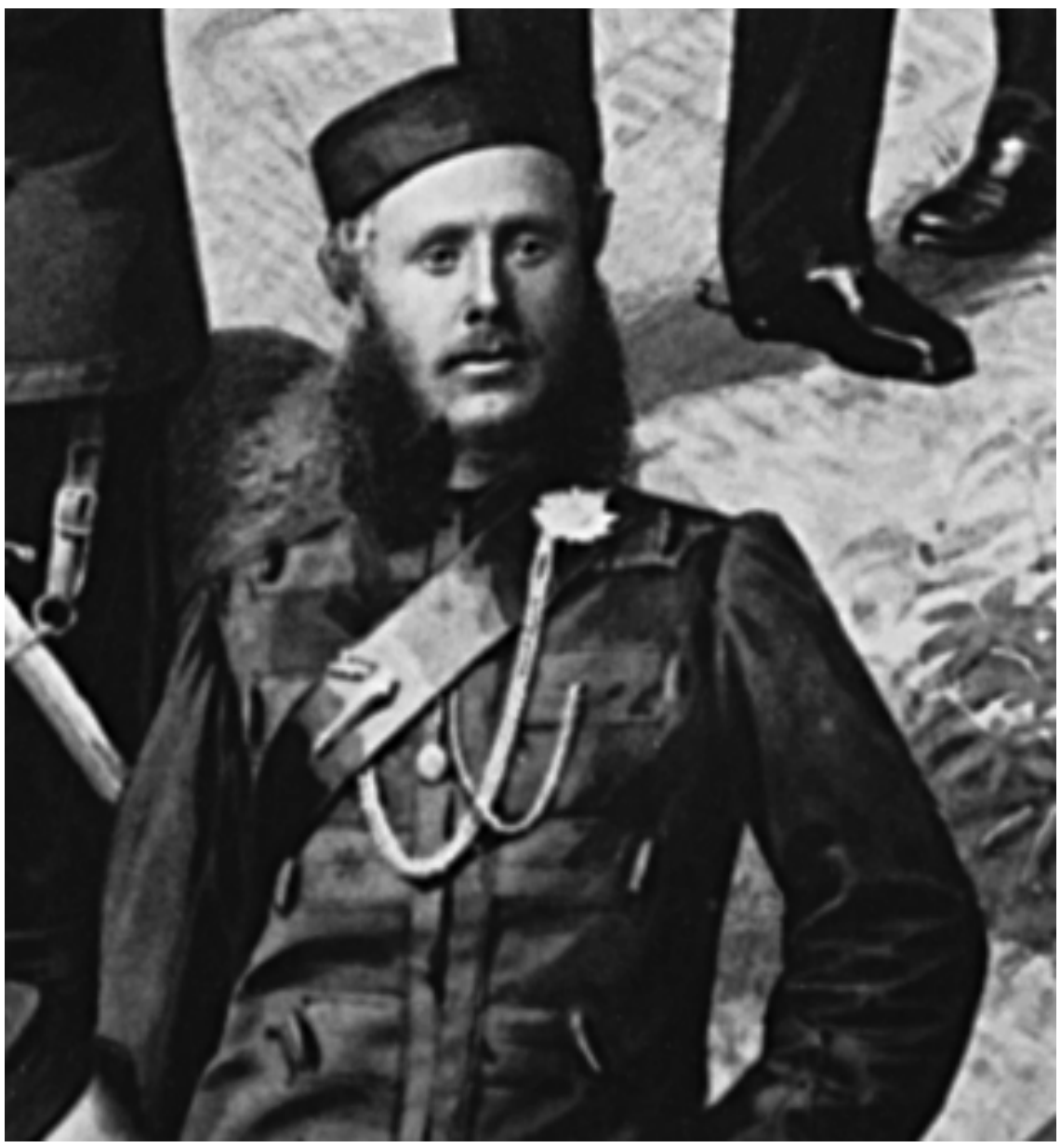

Close-up of “Victoria Rifles, Montreal, QC, composite by James Inglis, 1870” by James Inglis, albumen print, 32 x $47 \mathrm{~cm}$ McCord Museum Collection, MP-1986.21. 


\section{James Inglis' Negative Numbers}

As previously discussed in "Relationship between the Album Pages and Related Documents" section of this chapter, a definite match between the portrait of Mrs. Sharpley on Album Page \#22 and the negative number 34358 in the related documents has been established. In this formal portrait of Mrs. Sharpley (ill. 15; pg. 53) she is seated in front of a painted backdrop, holding a parasol. The same painted backdrop can be seen in the McCord Museum's portrait of James W. Pyke, (ill. 23; pg. 67). This portrait is a carte-de-visite that is made by the James Inglis Studio, indicated by the insignia on the verso that reads, "J. Inglis 101 Great St. James Street, Montreal" underneath an elaborate crest with a beaver and the Latin phrase, "Concordia Salus", which means "well-being through harmony" and is also the motto of the City of Montreal. It is $6.2 \times 10.1 \mathrm{~cm}$ in size, so slightly larger than the $5 \times 7 \mathrm{~cm}$ photographs in the album pages, but it is the same albumen process. Although, not perhaps noticeable immediately, the painted diagonal shadows that fall above Mrs. Sharpley's head are identical to the painted diagonal shadows that are on the right side of the photograph of Mr. Pyke. The painted backdrop consists of a column, with five vertical flutes, next to an open thin French door and a tropical, broad-leaf plant in a basket-weave pot, most of which is more visible in Mrs. Sharpley's portrait. Also, the desk leg that is in the left foreground of Mrs. Sharpley's portrait can be matched to the desk to the right of Mr. Pyke.

This discovery's significance is a two-fold. Firstly, it is fundamental to attributing a number of portraits in the album pages to the James Inglis Studio. Thirty-eight of the photographs have the same backdrop as Mrs. Sharpley and Mr. Pyke. This finding has tremendous potential because portrait studios had a variety of props that were reused in 
multiple combinations in each sitter's portrait. This means that once one piece of studio décor is confirmed as belonging to the James Inglis Studio, other props that appear with it in one photograph can then be identified in even more portraits. The desk in Mr. Pyke's portrait, for instance, is repeated in five more of portraits and the statuette on the desk in is also repeated in two more portraits. Secondly, since Mrs. Sharpley's portrait can be concretely linked to the James Inglis Studio, via the identical setting as Inglis' portrait of Mr. Pyke, it can also be concluded that the five-digit negative numbers on the related documents, are in fact James Inglis' numbering system.

These efforts into understanding the negative number system of the James Inglis Studio could be extended with more photographic objects such as another "Picture Book" album or more carte-de-visites and cabinet cards that have negative numbers directly in the image or have the negative numbers written on the verso of the carte-de-visites and cabinet cards in pencil, which is also common. This research will lead to identifying more sitters, dating objects, and ultimately a better understanding of the practice of the James Inglis Studio. 


\section{Illustration 23:}

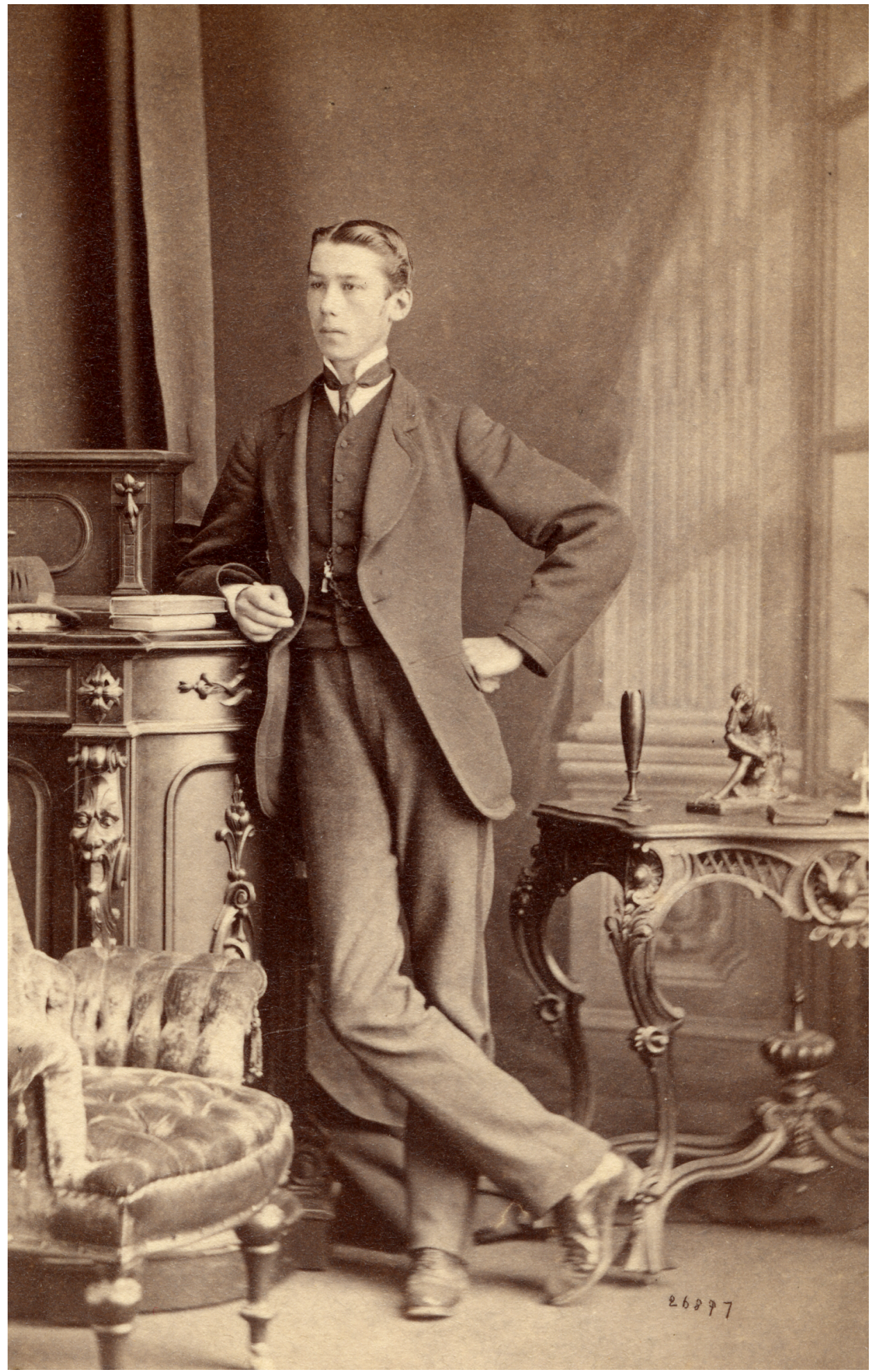

“James W. Pyke, Montreal, QC, about 1870” by James Inglis, negative number: 26897, albumen print, 10.1 x $6.2 \mathrm{~cm}$, McCord Museum Collection, MP-0000.116.6. 


\section{Dating the Objects}

It is uncommon to have an exact date when dealing with material that has been separated from its original function. This is compounded by the fact that the various objects in the group may have been created over time, and that these different kinds of objects have their own dating complexities. With the proper application of in depth research, however, an accurate date range can be ascertained.

This group of objects has multiple dates that can be associated with it: there are the dates of the photographs (both the negative and print dates); the dates the assemblage of the album pages; the dates of the ink inscriptions and the pencil annotations in the index book, which may or may not have been made at the same time; and the dates when the related documents were assembled or written. Some of these dates (such as the pencil inscriptions in the index book and the related documents) may be the same.

The negative dates of all 579 photographs in the album pages are determined by the individuals pictured, their age, and their clothing. The biographies of the men and women pictured can aid enormously in determining the negative dates. Unfortunately, due to the large number of portraits, the task of dating each individual's portrait goes beyond the scope of this thesis. However a few portraits can be securely dated. One example is from the group of six portraits of Prince Arthur, Duke of Connaught and Strathearn (1850-1942; ill. 18; pg. 59). These portraits, which happen to be on the first page of the album page stack, Album Page \#33 (ill. 1; pg. 16), are extremely helpful in this dating strategy. According to the Canadian Heritage website, "Royal Visits from 1786 to 1951 - Monarchy in Canada", "Prince Arthur, later Duke of Connaught, spent a 
year in Canada with the Rifle Brigade based at Montreal in $1869-70 .{ }^{.43}$ As a result, this photograph was taken between 1869 and 1870 .

Another example that suggests the photographs were taken in the 1860 s or early 1870 s is that the fore mentioned composite by Inglis titled "Victoria Rifles" (ill 19; pg. 61) was also made in 1870 . There are four portraits in the disbound album pages that are exact matches to the negatives used to make this composite. They are as previously mentioned, Colonel John M. Crawford, Taylor Homer, Colonel E. A. Whitehead and Capitan E. B. Greenshields. If the composite was assembled in 1870 the portraits must have been taken in 1870 or slight earlier, but likely not much earlier since the photographs were probably taken for this specific composite. The Victoria Rifles Brigade, "was organized in Montréal in 1861 by members of the Beaver Lacrosse Club in response to the strain in Anglo-American relations brought on by the American Civil War. In 1862 the Rifles were officially recognized as a Canadian militia unit under the name, the Third Battalion Victoria Volunteer Rifles. ${ }^{, 4}$ Thus, these portraits could have only been taken after 1862 since the men are in military uniforms.

The fore-mentioned portrait of Henry Morgan (ill. $16 \& 17$; pg. 57-59) also provides evidence of the negative dates of the photographs. The carte-de-visite, as previously discussed, has an elaborate crest on its verso that confirms it was made by the James Inglis Studio. Fortunately, the carte-de-visite still has its original envelope from the studio. This small, cardboard envelope has another, different elaborate design with scrolls that reads, "J. Inglis, Photographer, Great St. James St., Montreal" and a pencil

\footnotetext{
43 "Royal Visits from 1786 to 1951 - Monarchy in Canada," Canadian Heritage, last modified: June 3, 2011, accessed on: July 20, 2012, http://pch.gc.ca/eng/1307123137189/1307123947930

44 "Victoria Rifles of Canada fonds (P190): Administrative History - Biographical Sketch,” McCord Museum, accessed on: July 25, 2012, http://www.mccordmuseum.qc.ca/scripts/explore.php?Lang=1\&tableid=18\&tablename $=$ fond\&elementid $=46$ true.
} 
inscription on both sides of the envelope that reads, "Henry Morgan". The address provides a date range for the production of this carte-de-visite. As will be described in detail later in this section, the James Inglis Studio resided on Great St. James Street between 1866 and 1872. It can be deduced that this photograph, and many of the others, were produced in this time period. The fore-mentioned portrait of Pyke also has the James Inglis Studio address of 101 Greater James Street on it, which would further support this dating of 1866 to 1872 .

A broad survey of the 579 portraits also aligns with this time period. The elaborate studio décor and props found in the portraits is characteristic of studio portraiture in the second half of the nineteenth century. As McCauley explains, "between 1850 and $1870 \ldots$ the use of accessories and backdrops which encased the sitter in a prefabricated, cubical environment... were slow to disappear." ${ }^{45}$ McCauley describes this type of portraiture as "materialistic", and it is heavily represented in the portraits on the disbound album pages. Also, the clothing worn by the sitters indicates that the portraits were taken in the late Victorian era. Joan L. Severa's book Dressed for the Photographer: Ordinary Americans and Fashion, 1840-1900 is a very valuable resource when dating commercial portraits. She identifies trends and conventions in each decade. Although most of the portraits are of men on the album pages, women's fashion trends are typically more distinct and fleeting, allowing for an easier identification and more accurate date range. As an example the portrait of Mrs. Sharpley (ill. 15; pg. 53) will be used. In her portrait, Mrs. Sharpley is holding a parasol. According to Severa, "Still an important accessory, the typical parasol of the sixties was long and of one piece, rather

\footnotetext{
${ }^{45}$ McCauley, Likenesses: Portrait Photography in Europe, 1850-1870, 9.
} 
than the folded carriage shape, and fancy handles were in vogue." ${ }^{46}$ The former is a fitting description of Mrs. Sharpley's parasol and thus it is likely that this portrait was taken in the 1860's. Since the majority of the photographs are characteristic of commercial portraiture of the mid nineteenth century and the fashion trends of the sitters also align with this, it seems likely that most of the portraits were made from the mid 1860 s to the mid 1870 s.

Determining the print date of a photograph is an even more challenging undertaking for a photographic historian. Without contextual information that specifically pertains to the matter, a print date is very difficult to determine with any certainty. This is largely because the most reliable evidence is the photographic process used to print the photograph. Each process does not have an exact date range, but an approximate time span in which it was in fashion and was commonly used. Due to the color of the photographs on the disbound album pages it can be determined that they are printed-out photographs, instead of developed-out, because "while developed images generally are black (sometimes with a greenish or bluish cast), the color of printing-out papers after fixation is usually yellowish or reddish brown." photographs indicate that they are albumen, one of photography's widest used processes in the second half of the nineteenth century. According to James Reilly, the founder and current director of the Image Permanence Institute, "the period 1860-1885 is a time of reasonable certainty with regard to process identity, and there is a great likelihood that any given silver photographic print of that period was made on albumen paper. Studio

\footnotetext{
${ }^{46}$ Severa Joan L, Dressed for the Photographer: Ordinary Americans and Fashion, 1840-1900 (Ohio: The Kent State University Press, 1995), 199

${ }^{47}$ James M. Reilly, The Albumen \& Salted Paper Book: The History and Practice of Photographic

Printing, 1840-1895 (Light Impressions Corporation: Rochester, 1980), 3.
} 
portraits (except life-size enlargements) and stereo views of this era are especially likely to be albumen prints." ${ }^{" 48}$ While the exact print date of these photographs is not known, their subject matter, albumen process and the photographer's studio dates does make it likely that they were printed between 1866 and 1900 .

Thus far, it has been determined that many of the photographs can be attributed to the James Inglis Studio, that the negatives were made in the 1860s and 1870s, and that the photographs were printed between 1866 and 1900. An investigation into the fate of James Inglis' negatives is worthwhile in hopes of further narrowing down the print date of the photographs. James Inglis moved his studio in Montreal a number of times. A Montreal historian's greatest resource for tracking individuals and businesses are the Annuaires Lovell de Montréal et sa banlieue, ${ }^{49}$ which run from 1842-1999. This invaluable directory of information about the population, businesses, and institutions in Montreal confirms the existence and tracks the four location of the James Inglis Studio in Montreal from 1866 to his departure from the city in 1884. Inglis' first studio was at 122 Greater St. James Street in 1866. Then, the business was located at 101 Greater St. James Street from 1867 to 1872 . Then it was at $195 \frac{1}{2}$ St. James Street for two years (1872 and 1873) until moving to the business' last address of 51 Bleury Street, where it existed between the years 1874 and 1884.

In 1873 or 1874, Inglis sold his studio at $195 \frac{1}{2}$ St. James Street to the photographer J. G. Parks. Reichstein discusses this sale,

During the period between June 1873 and June 1874, Inglis sold his studio and its contents, including negatives, to

\footnotetext{
48 Reilly, The Albumen \& Salted Paper Book: The History and Practice of Photographic Printing, 1840$1895,123$.

${ }^{49}$ Annuaires Lovell de Montréal et sa banlieue (1842-1999). Collection numérise. (Bibliothèque nationale du Québec 2005) http://bibnum2.bnquebec.ca/bna/lovel1/
} 
another Montreal photographer, J. G. Parks, and having done so immediately opened another studio at 51 Bleury Street which he was to occupy until his departure from Montreal some ten years later. The reasons for the sale remain a mystery. ${ }^{50}$

Advertisements in primary sources confirm the sale of the studio and negatives. In his advertisement in the August, 1875 edition of The International Railway and Steam Navigation Guide, (ill. 24; pg. 76). Parks used this as a marketing ploy stating, "J. G. Parks has purchased the entire stock of negatives taken by J. Inglis, for the last six or seven years, and will furnish his former customers with these Photographs [SIC], from the same, at the Old Stand, 1951/2 St. James Street, Montreal."51. Parks used this sale again in advertisement from the 1878-79 Vennor's Almanac and Weather Record (ill 25; pg. 77), which states, "Mr. Parks has the negatives taken by Mr. Inglis on St. James Street." 52 These advertisements shed light on the printing of the photographs because they raise the possibility that Parks printed the photographs, instead of Inglis. They do not, however, narrow the print date of the photographs. To determine this, an analysis of the photographs printed by both photographers would need to be carried out. Until further research is done, it seems best to leave the print date of the photographs between 1866, when Inglis first opens his studio and 1900.

The photographic portraits also provide evidence of the earliest approximate date for the assemblage of the album pages, index book, and related documents. They could not have been put together until after the latest possible negative date of the portraits. The

\footnotetext{
${ }^{50}$ Reichstein, James Inglis (1835-1904): Montreal, Rochester, Chicago, part 1, 7.

${ }^{51}$ The International Railway and Steam Navigation Guide (Montreal: C. R. Chrisolm \& Bros., August 1875), 58

${ }^{52}$ Vennor's Almanac and Weather Record (Montreal: J. Lovell \& Son, 1878-79), 19
} 
fore-mentioned portrait of Prince Arthur confirms that they could not have been compiled until after 1870.

The inscriptions in the index book allow one to date its production. The same individual who wrote the pencil "Portrait Sequence Numbers" wrote the negative number lists on the related documents, which could not have happened until on or after February 1890 , due to the dates of the typed letters on the verso. The ink inscriptions in the index book, however, can also help date the assemblage of the objects. The ink inscriptions consist mostly of surnames but occasionally there are occupations scribbled next to some names. Two examples will help to clarify this. The first appears in the "B" page, "Beaugrand H. Mayor La Patrie". This, of course, is referencing Honoré Beaugrand (1848 - 1906), a well-known French Canadian politician, author, and newspaper owner, whose portrait has been now identified in the album pages (ill. 26; pg. 78). Beaugrand was mayor of Montreal for two years, between 1885 and 1887, and he established his French language weekly newspaper, La Patrie, which is referenced in the index book inscription, in 1879. These dates reveal that the author of the index book ink inscriptions could only have written this inscription after 1887 . The second inscription is on the "O" page. Under the Ogilvie brothers, H. W. and W. W., is written "Ogilvie, Dead". The corresponding portrait in the album page (ill. 27; pg. 79) has been matched with a William Notman's portrait of John Ogilvie (ill. 28; pg. 80) who died after sustaining leg injuries and a subsequent heart condition in $1888 .^{53}$ This confirms that the earliest date that the index book was created and perhaps used with the album pages was 1888 or later.

\footnotetext{
${ }^{53}$ John Alexander, The Ogilvies of Montreal, with a Genealogical Account of the Descendants of their Grandfather, Archibald Ogilvie. (Gazette: Montreal, 1904), 49-50.
} 
If the album pages themselves are considered, the earliest date of their assemblage is later still. The maker's mark on Marjorie Futcher-Howard's "Gilson Adjustable Album" (ill. 9; pg. 33) reads that the U. S. patents were either filed on or issued on (it is not specified) on May 6, 1890 and again on June 22, 1897. Also the U.S. patent for the "Gilson Separable Book" was filed on February $15^{\text {th }}, 1897$ and issued on November $23^{\text {rd }}$ of the same year. If the album was bought in Canada, however, the Canadian patent for the Gilson Separable Book was filed on November $8^{\text {th }}, 1897$ and issued on January $7^{\text {th }}$, $1898 .^{54}$ With all this in consideration it is logical to establish that the album pages, index book, and related documents were all assembled after 1890 but likely in or around 1897.

\footnotetext{
54 “Canadian Patents Database," last modified July 3, 2012, http://brevets-patents.ic.gc.ca/opiccipo/cpd/eng/patent/58935/summary.html?query=Gilson\&start=1\&num=50\&type=basic_search\#View_Im ages
} 


\section{Illustration 24:}

\section{J. G.:P A RK S \\ MAKES: THE FHNEST

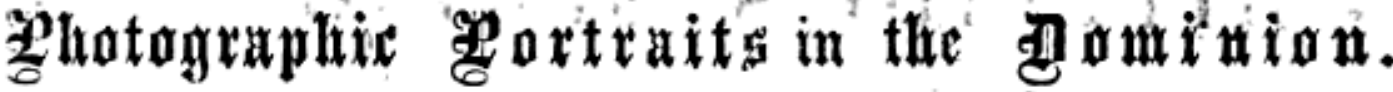

J. G. PARKs has taken and refitted the rooms formerly occupied by $J$ Inglis, where with increased faciliti, $\mathrm{E}$, he is in hopes to please those who may favour him with their patronage.

J. G. PARKs has purchased the entire stock of negatives taken by J. Inglis, for the last six or seven years, and will furnish his former customers / with these Photographs, from the same, at the Old Stand, 195 $\frac{1}{2}$ ST. JAMES STREET, Montreal.

Three First Prizes and an EXTKA PRIZL âcarded to J. G. PARKs at Provincial Exhilitio," 18:0, alsn'tico Porst Prizes 1868.

"J. G. Parks advertisement," in The International Railway and Steam Navigation Guide, Montreal: C. R. Chrisolm \& Bros., August 1875, pg. 58. 


\section{Illustration 25:}

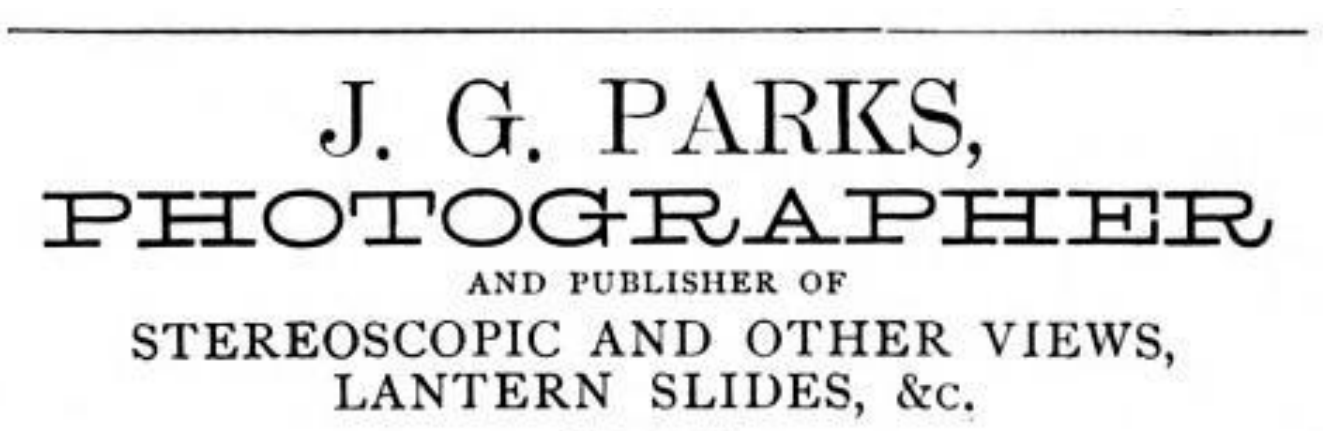

Mr. Parks has the old negatives taken by Mr. Inglis on St. James Street. Photographs furnished from the same.

Mr. Parks has a large assortment of Stereoscopic and large Photographic Views, Lantern Slides, \&c. Liberal discount to the trade.

Catalogue sent free.

Give him a call if you need something in the photographic line.

Mr. Parks holds a number of First Prizes awarded at various Ex. hibitions.

$$
\text { J. G. PARKS, }
$$

$195 \frac{1}{2}$ ST. JAMES STREET, MONTREAL.

“J. G. Parks advertisement," in Vennor's Almanac and Weather Record, Montreal: J. Lovell \& Son, 1878-79, pg. 19. 


\section{Illustration 26:}

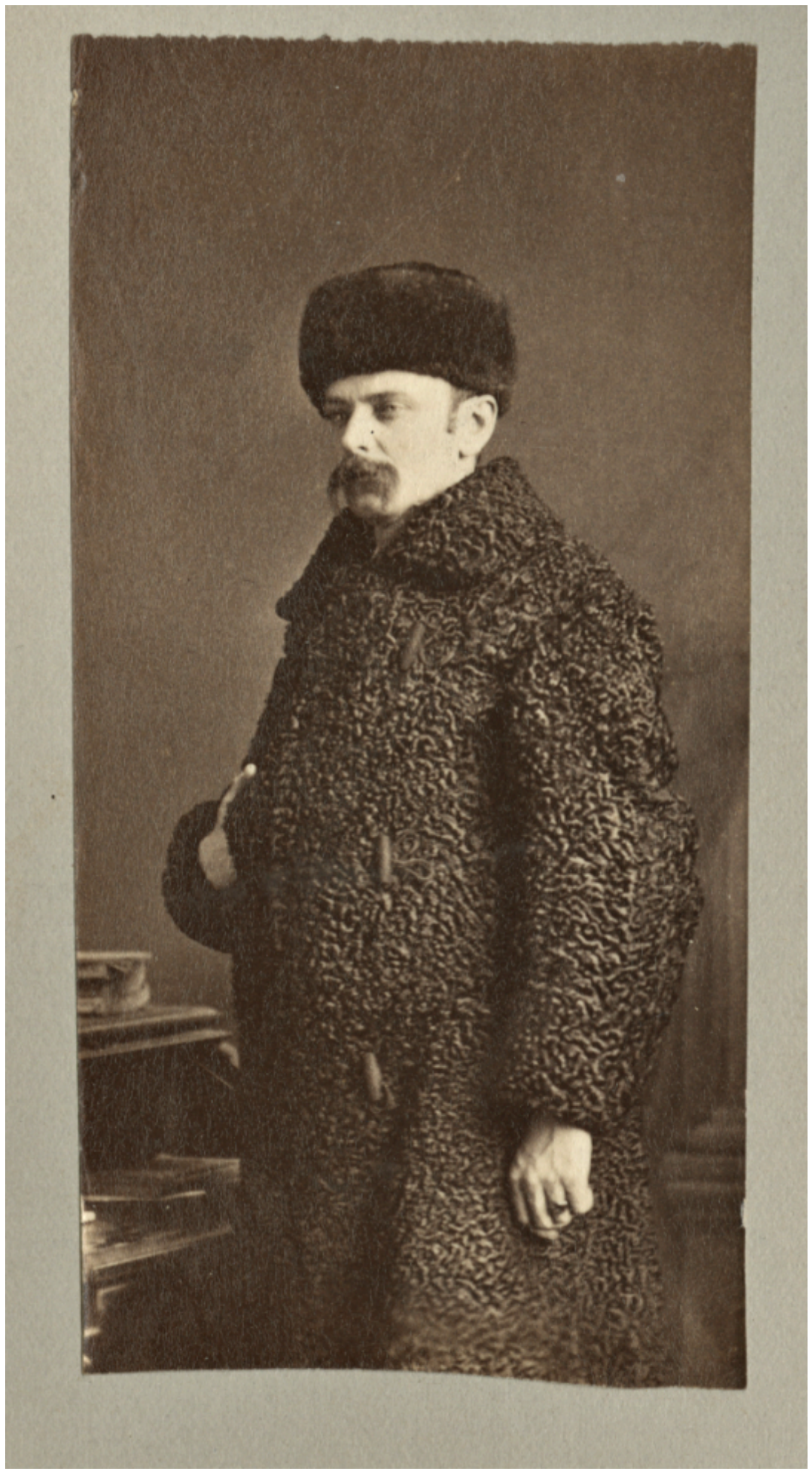

"Hon. Beaugrand, Album Page \#17, Image 11," albumen print, 5 x $7 \mathrm{~cm}$ McCord Museum Collection, M15955. 


\section{Illustration 27:}

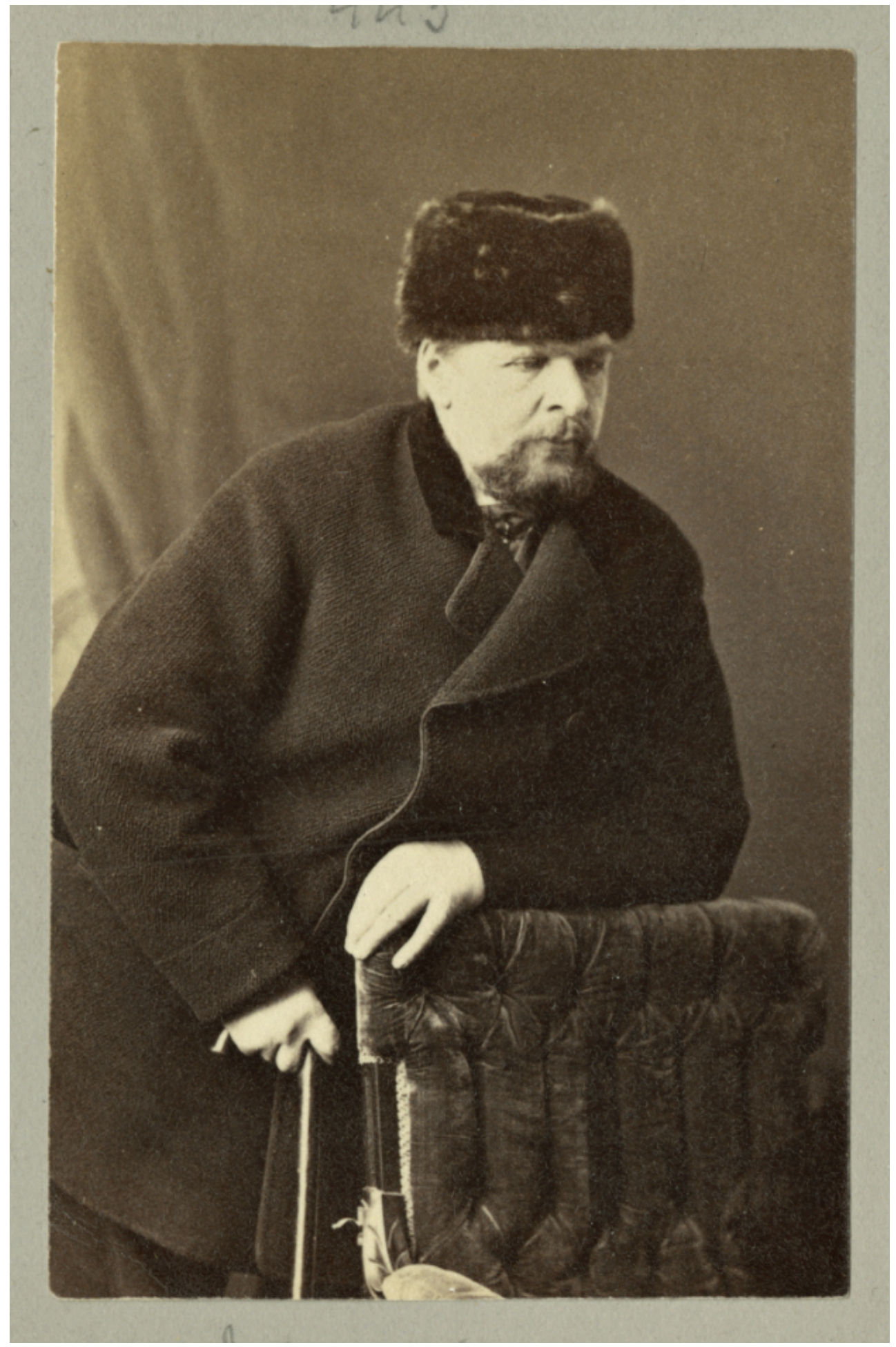

“Ovilgie Dead, Album Page \#11, Image 3," albumen print, 5 x $7 \mathrm{~cm}$ McCord Museum Collection, M15955. 


\section{Illustration 28:}

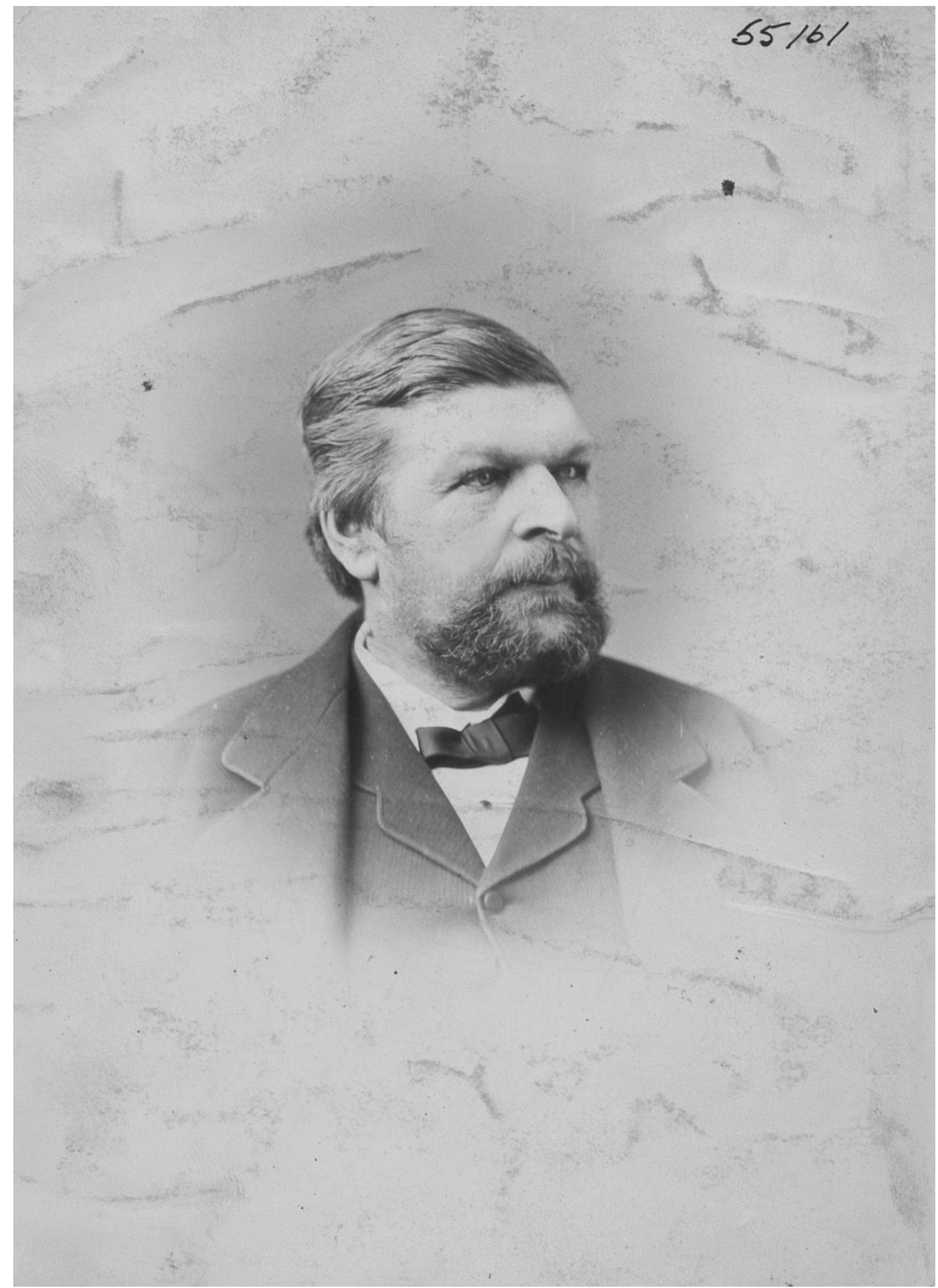

“John Ogilvie, Montreal, QC, 1880” by William Notman, albumen print.8.5 x $5.6 \mathrm{~cm}$ McCord Museum Collection, II-55161.1. 


\section{Original and Subsequent Functions}

Each component of this group of photographic objects - The photographs in the album pages, the album pages themselves, the index book, and the related documents would have had a specific function, which is dependant on when it was created and how it was used. Similarly, because the objects are inter-related, they have a combined purpose that is dependant on when they were brought together. These multiple trajectories of different and related functions over time and space all converge at the McCord Museum. This section defines their purposes within the museum by exploring and speculating on the multiple possible functions of each part and the whole of the group over time.

Beginning with the photographs, presumably the negatives that produced these portraits were made at the request of the individual who wished his or her portrait to be made. The negatives may have been printed as carte-de-visites or cabinet cards and dispersed amongst family and friends. The photographs in the disbound album pages, however, presumably at a later time, were selected, likely from a much larger group of portraits, gathered together, sequenced, and pasted in the album pages. The album pages match the pages of the "Gilson Adjustable Album". This type of album is manufactured to be easily adjusted - in a form that more pages could be added, ones removed and the order changed and re-arranged. This changeability that the album pages allows suggests that, even its very first arrangement or assemblage was susceptible to change - which means that the order and even function of the album pages have always been in flux. The index book's pages hold a mélange of annotations; some are in ink and some are in pencil, and there are two distinct styles of handwriting. This reveals that the inscriptions 
in the book have quite possibly been added at a minimum of two different times and for different reasons. The four related documents appear to be linked to the index book by matching handwriting style (in the case of the pencil inscriptions), and while this suggests the same author it does not suggest that the purpose of the two objects is the same. Two of the related documents have typed correspondences on the verso, which shows a clear purpose of communication between two or more unknown individuals. This original function of the letters was altered once the lists of negative numbers and names were written on the other side of the sheet, either before or after the letter was typed, although likely the latter.

At the McCord Museum, this group of objects is referred to by the curatorial staff as the "James Inglis Picture Book". This designation is not inscribed anywhere on the objects or in the museum's database. The current curator and archivist of the photography collection are unsure of how this group of objects received this designation. Therefore a previous staff member, possibly Stanley Triggs, the former archivist of the Notman Photographic Collection at the McCord Museum, may have recognized some of the numerous James Inglis Studio portraits within the album pages, and may have referred to it as the "James Inglis Picture Book".

As this thesis' research has shown, however, these objects have too much dissimilarity to the two "Picture Books" that the McCord has from the James Inglis Studio to be another "Picture Book". "Picture Books" are arranged chronologically, and they were added to as the sitters came into the studio and were photographed, whereas, the disbound album pages are in loose alphabetical order, which was not the order in which the portraits were taken. Physically, the disbound album pages do not resemble the 
thin paper pages in the large leather bound "Picture Books" either. The photographs in the disbound album pages, while they are the same size and process as those in the "Picture Books" - all are albumen prints -, do not have the negative numbers inscribed underneath them and are not arranged in numerical order. The portraits in the disbound album pages are not easily referenced; therefore they are not an effective business filing system as the "Picture Books" are. Also, because of the earliest possible date for assemblage is 1890 , these objects could not have been used in the James Inglis Studio, because James Inglis left his studio in Montreal and moved to Rochester, New York in 1884 to establish a dry plate manufacturing company. ${ }^{55}$

While dissimilar to the other "Picture Books", both organizationally and physically, this group of album pages could have been used in a commercial portrait studio, perhaps as a reference album of well-known Montreal citizens. As previously discussed, Inglis sold his studio at $195 \frac{1}{2}$ St. James Street and all of his negatives to J. G. Parks in 1873 or 1874. If Parks did in fact print the photographs, he could have assembled them in these album pages after 1890 because Parks remained a studio photographer up until $1894 .^{56}$ He did, like Inglis, move his studio around Montreal a number of times between 1874 and 1894 but it is rare that a studio photographer would sell their entire archive of negatives as Inglis did. The alphabetical arrangement of the disbound album pages lends itself to this scenario because it is likely that Parks used Inglis' negative number system and Picture Books but also wanted another reference album to be able to look up wellknown individuals by their names.

\footnotetext{
${ }^{55}$ Irwin Reichstein, e-mail to author, 12 Jun 2012.

${ }^{56}$ Annuaires Lovell de Montréal et sa banlieue (1842-1999). Collection numérise. (Bibliothèque nationale du Québec 2005) http://bibnum2.bnquebec.ca/bna/lovell/
} 
Another possible scenario in which these object could have functioned together is that an independent researcher or historian assembled them perhaps as a record of prominent Montreal citizens from the 1860's and 1870's. The negative number lists being written on the verso of the typed letters lend itself to this scenario because it seems as though the unrelated letters were used as scrap paper. These typed letters are dated 1890 . As mentioned in the previous section, the index book and album pages could have only been assembled in or after 1890 as well. This would make the letters contemporaneous with the rest of the objects and likely on the author's desk at the time that these objects were being assembled. As mentioned, the recipient of the letters would likely have been one of the over three hundred governors on the board of the Montreal General Hospital. Perhaps one of these men had a hobby or interest in Montreal history and was responsible for assembling this material.

What is certainly clear is that the former individual and combined functions these objects are now elusive and conjectural. It is not certain that all of the objects were created either at the same time or for the same purpose(s). The objects' original functions may have entirely disappeared or have been incorporated into later ones as additional objects were added or, equally possible, objects lost. According to one of the accompanying acquisition notes, it seems that there was an envelope of photographs that is currently unaccounted for. These missing photographs could have possibly helped to reveal more about the intended function of the group of objects. Nevertheless, what this section shows is that as these objects have moved through space and time their function(s) have evolved. 


\section{JAMES INGLIS' BIOGRAPHY}

Little is known about the Scottish-born, Canadian portrait photographer James Inglis (1835 -1904) and even less has been published about his life and work, despite being one of William Notman's (1826 - 1891) biggest competitors in Montreal in the second half of the nineteenth century. The photographer's near exclusion from the history of Canadian photography is curious since Notman has become a household name in this history and the James Inglis Studio was relatively successful in comparison to the other studios in Montreal during its day.

Irwin Reichstein, a nineteenth century photography enthusiast and author of the one of the few secondary sources dedicated to Inglis, published the biography of James Inglis in his 1997 two-part article in Photographica Canadiana ${ }^{57}$ Here it is learned that James Inglis was born on June $12^{\text {th }}, 1835$ in Scotland, and emigrated to St. Catherines, Ontario in 1856, where he worked as an "ambrotypist" in a studio that he purchased in 1863. Two years later, in 1865 he came to Montreal and applied to work for William Notman, a fellow Scottish immigrant. When he was rejected, he opened his own portrait studio a few months later in 1866 on Greater St. James Street. Despite having his own studio, Inglis did have his own portrait taken at the William Notman Studio is 1866 (ill. 29; pg. 89). Becoming a fiercer competitor in the late 1860s, in 1874 Inglis moved his studio to 51 Bleury Street, close to William Notman's very successful studio at 17 Bleury Street.

Reichstein not only unearths facts about Inglis' career, but also illuminated aspects of this photographer's character by quoting from friends' and peers' written accounts of him. This insight into Inglis' personality helps to understand his career,

${ }^{57}$ Reichstein, James Inglis, Montreal, Rochester, Chicago, Part $1 \& 2$ 
"which underwent continuous change, both with regard to physical location as well as to the nature of his photographic enterprise. ${ }^{958}$ Despite his successful commercial studio in Montreal, Inglis moved to Rochester, New York to pursue a career in dry-plate manufacturing - a burgeoning photographic technology - in 1884. E.A. Dumble, a prominent Rochester photographer and dry plate manufacturer and who was his first American partner for only two months wrote,

You know Mr. Inglis is a Scotchman; a minute's conversation with him will settle that point... There is a striking individualism in his speech, as in everything else the man does. Five feet eleven in his summer stockings, is his exact measure by the tape when not unduly excited... Always exploring for something new, original and aggressive in his ideas, there are many who think him combative and belligerent when in fact it is but the powerful personality of the man trying to vindicate itself against all comers. Inglis has always struck high and several times has reached the point where a feather's weight, a breath would have tripped the trembling scales to great success, but the fortunes of war have been against him. ${ }^{59}$

Dumble paints a picture of a man who was physically large, excitable, and strongminded. Inglis was a natural innovator and was not afraid to take risks, many of which did not always work in his favor.

In 1904 Inglis died as a result of an accidental explosion in his basement at his residence in Chicago while experimenting with magnesium flash powder. Frederick Dundas Todd (1858-1927) the founder and editor of a photographic journal The PhotoBeacon and a long-time friend, comments on Inglis' nature in his eloquent obituary,

To many he was a big puzzle, but to me he was an open book simply because as a fellow countryman, I had met many of his type of mind though few were so big. Logically and theologically, he was of the type that made the Scotch covenanters of the sixteenth century, and once he accepted any premises he was so constituted that he followed every

\footnotetext{
${ }^{58}$ Irwin Reichstein, “James Inglis, Montreal, Rochester, Chicago”. Part 1. Photographica Canadiana. (May/June 1997): 5

${ }^{59}$ Ibid
} 
conclusion to the limit without fear of the consequences to himself or anybody else. Herein lay his greatest power but it was also his greatest weakness. $^{60}$

Again, Inglis is described as a man who took risks, regardless of the consequences. Reflecting on Reichstein's articles on Inglis' life and career, it seems that he had shining moments of accomplishment but was unable to stay content with what he had created. $\mathrm{He}$ was a restless entrepreneur, which in the constantly evolving business of nineteenthcentury photography meant he was a fierce, determined, yet fleeting competitor to those around him.

Nowhere is Inglis' competitive spirit more apparent than in the saga of the Victoria Skating Rink composite contest. As mentioned, Prince Arthur was visiting Montreal in 1869 and to honor him the city of Montreal held a skating carnival at the Victoria Skating Rink. The Victoria Skating Rink was built in 1862 and was still considered, "one of the finest covered rinks in the world" ${ }^{61}$ in the twentieth century. In response to this event, Inglis planned to make a composite photograph that depicted the carnival and so did Notman. As Reichstein explains,

The news that his rival, Notman, was producing a composite of the same event no doubt infuriated Inglis who issued a public challenge in the Montreal Daily Witness of February 26, 1870. In it, Inglis made the claim that the manner of carrying out the composite photograph had originated with him and he called for a jury, picked by the event organizers, to judge the relative merits of the respective pictures, the losing party to give two hundred dollars to charity. ${ }^{62}$

\footnotetext{
${ }^{60}$ Reichstein, "James Inglis, Montreal, Rochester, Chicago". Part 1, 5

${ }^{61}$ N.M. Hinshelwood, Montreal and vicinity: being a history of the old town, a pictorial record of the modern city, its sports and pastimes, and an illustrated description of many charming summer resorts around. (Montreal: DesBarats \& Co., 1905), 89

${ }^{62}$ Reichstein, "James Inglis, Montreal, Rochester, Chicago". Part 1, 7
} 
It is not known if Notman accepted Inglis' challenge and if he did, the results of this competition are unknown. In July of 1870, however, Canadian Illustrated News reprinted an article titled, "Examples of American Photography" that was originally published in London Photographic Times that stated,

Mr. Notman also sends us the most perfectly composed group we have ever seen produced by photography. The subject is what is termed a 'skating carnival'... Since the receipt of this group, we have received two others of a similar character, but on a larger scale, by Mr. Inglis, of Montreal. One of these consists of the subject just describe, the carnival of the Victoria Skating Rink, and the other the opening of the Montreal Curling Rink. The latter was the first composition of its kind produced, and was the origin, we understand, both of Mr. Inglis's [SIC] own skating carnival group, and that of Mr. Notman. ${ }^{63}$

It is clear that the London Photographic Times preferred Notman's composite photograph aesthetically, but Inglis, never to be outdone, sent in, not one, but two of his works. From the way the article is phrased it seems that Inglis wrote to the editors and explained he was the first to make a composite photograph and that Notman, essentially copied him. Whether or not this is true, is uncertain. What this does indicate, however, is the competitive environment of surrounded commercial photography in the nineteenth century; an environment that James Inglis seemed to thrive in.

\footnotetext{
${ }^{63}$ Canadian Illustrated News, "Examples of American Photography" (Montreal: Desbarats \& Co., July 23, 1870), 59
} 


\section{Illustration 29:}

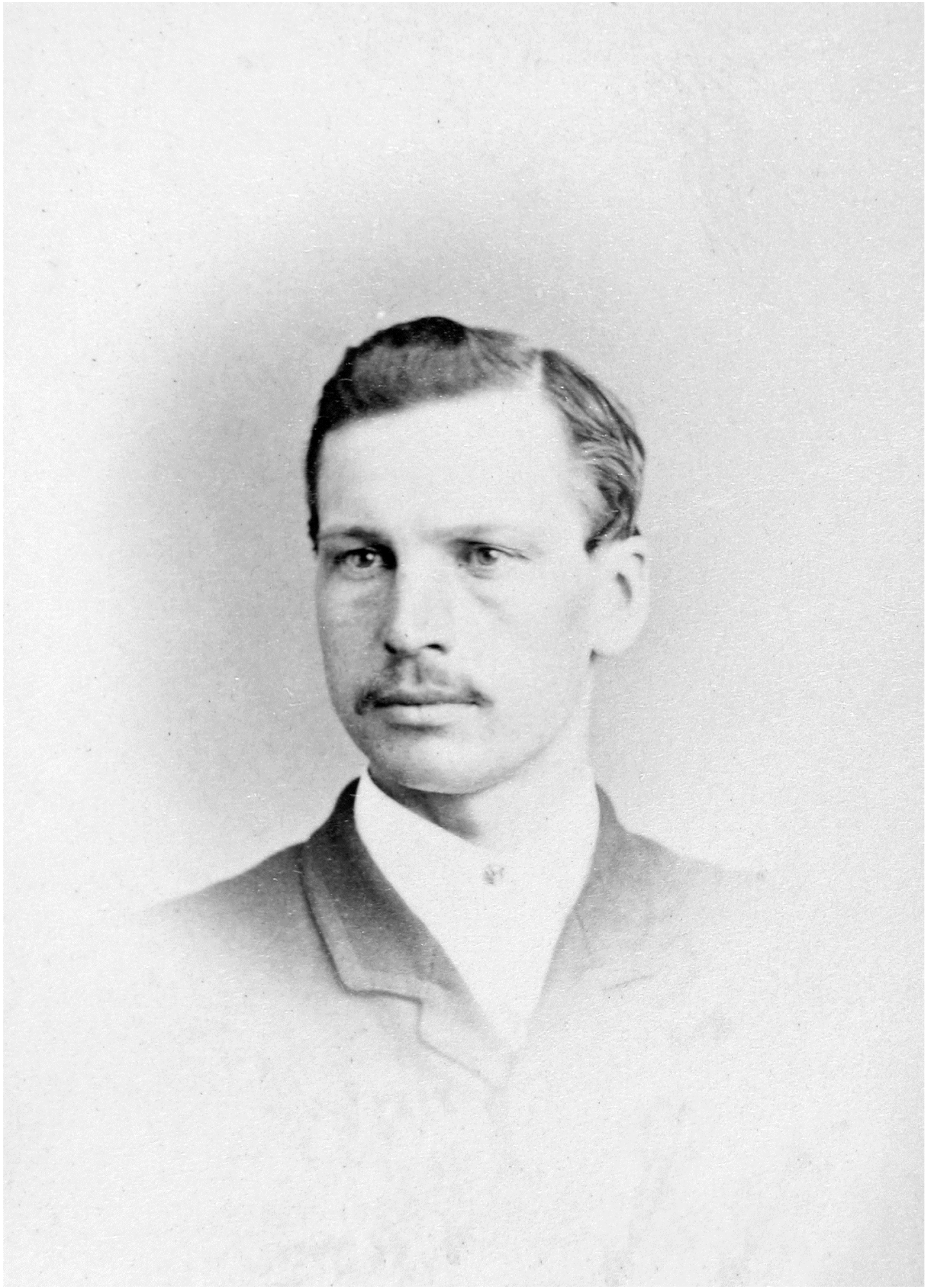

"James Inglis, photographer, Montreal, QC, 1866" by William Notman, albumen print, 8.5 x $5.6 \mathrm{~cm}$ McCord Museum Collection, I-21789.1. 


\section{CONCLUSION}

The history of photography has become anchored in the study of photographic objects, both as physical entities and as historical artifacts. This thesis is an exploration of not only how to approach the study of inter-related groups of photographic objects, but also what can be ascertained when this is carried out thoroughly and systematically. The main objective in embarking on this sort of research is to ensure that all hypotheses about the intellectual organization, the date(s) and the original function(s) of the objects are derived from the evidence found in the actual physical qualities of the objects. A comprehensive physical description is the basis of this methodology, so that no detail is overlooked and nothing was assumed. All hypotheses should be carried through as far as possible to ensure that all possible avenues are explored and a more full understanding of the objects is gained.

The research of multi-part, inter-related photographic objects is a considerable undertaking. This is especially true when an object-based methodology is employed because the project is guided by research. When this research began, the initial term used to describe the group of objects at the McCord Museum was the "James Inglis Picture Book"; however, instead of relying on this terminology, a detailed physical examination was carried out, and an analysis of the objects revealed that they were not likely used in the James Inglis Studio nor did they function in the same way as a "Picture Book" would have. Instead, the results of the research led to revising the dating of the assemblage of the objects to in or after 1890, long after the James Inglis Studio closed. The analysis of the organization of the objects led to many of the portraits being identified as well as being able to attribute many of the photographs to the James Inglis Studio. It also led to 
considering other functions that these objects may have had and that their purposes may have evolved over time, including possibly being made and used by J. G. Parks' Studio or an independent researcher.

Ultimately, these objects now function within the McCord Museum's collection and this research has facilitated this by making these objects more approachable and comprehensible for researchers. The objects can be used to help identify and possibly date other photographs of the individuals pictured. They can help with an understanding of Inglis' negative numbering system and in reference to the James Inglis Studio's décor and furniture. The pages can be used as an example of a Gilson Adjustable Album, just as the Futcher-Howard album was used in this thesis. The possibilities are tremendous. In a sense, this thesis has become part of the related material to the group of objects, and it is intended to cement them in the history of Montreal photography and define them as research tools given their current context within the McCord Museum's collection. 
APPENDIX I: Concordance of the Disbound Album Pages

This appendix documents the original order and, as a result of the fore mentioned research, the revised order the disbound album pages. The original order is listed in the first column and represents the order in which the "Album Page Identity Numbers" were found when research for this thesis began; these numbers are inscribed in pencil on the top left corner of each of the 39 disbound album pages. The revised order of the "Album Page Identity Numbers", is listed in the second column and is based on the "Portrait Sequence Number" hypothesis and subsequent research which is described in the section "Intellectual Organization: Relationship between the Album Pages and Index Book" of the Critical Analysis chapter (pg. 41). The revised order of the "Album Page Identity Numbers" now puts the portraits in loose alphabetical order. 


\begin{tabular}{|c|c|}
\hline $\begin{array}{l}\text { Original Order of "Album Page } \\
\text { Identity Numbers" }\end{array}$ & $\begin{array}{l}\text { Assigned Order of "Album Page Identity } \\
\text { Numbers" - Sitter Letter, Revised Pg \# }\end{array}$ \\
\hline 33 & $33-$ A Sitters, Revised Pg. 1 \\
\hline 17 & 17 - B Sitters, Revised Pg. 2 \\
\hline 30 & 19 - B Sitters, Revised Pg. 3 \\
\hline 5 & 9 - B Sitters, Revised Pg. 4 \\
\hline 16 & 30 - C Sitters, Revised Pg. 5 \\
\hline 23 & 24 - C Sitters, Revised Pg. 6 \\
\hline 12 & 5 - C Sitters, Revised Pg. 7 \\
\hline 9 & 12 - D Sitters, Revised Pg. 8 \\
\hline 15 & 16 - D Sitters, Revised Pg. 9 \\
\hline 31 & 27 - D Sitters, Revised Pg. 10 \\
\hline 10 & 23 - F Sitters, Revised Pg. 11 \\
\hline 18 & 15 - G Sitters, Revised Pg. 12 \\
\hline 2 & 31 - G Sitters, Revised Pg. 13 \\
\hline 35 & 3 - G Sitters, Revised Pg. 14 \\
\hline 20 & 18 - H Sitters, Revised Pg. 15 \\
\hline 8 & 10, H Sitters, Revised Pg. 16 \\
\hline 4 & 6 - J \& K Sitters, Revised Pg. 17 \\
\hline 7 & 38 - K Sitters, Revised Pg. 18 \\
\hline 11 & 2 - L Sitters, Revised Pg. 19 \\
\hline 34 & 20 - M Sitters, Revised Pg. 20 \\
\hline 28 & 35 - M Sitters, Revised Pg. 21 \\
\hline 1 & 7 - Mc Sitters, Revised Pg. 22 \\
\hline 21 & 8 - Mc Sitters, Revised Pg. 23 \\
\hline 22 & 4 - N Sitters, Revised Pg. 24 \\
\hline 24 & 11 - O Sitters, Revised Pg. 25 \\
\hline 3 & 34 - P Sitters, Revised Pg. 26 \\
\hline 25 & 28 - P Sitters, Revised Pg. 27 \\
\hline 13 & 26 - R Sitters, Revised Pg. 28 \\
\hline 36 & 1 - R Sitters, Revised Pg. 29 \\
\hline 6 & 22 - S Sitters, Revised Pg. 30 \\
\hline 14 & 21 - S Sitters, Revised Pg. 31 \\
\hline 19 & 25 - S Sitters, Revised Pg. 32 \\
\hline 26 & 13 - T Sitters, Revised Pg. 33 \\
\hline 17 & 29 - U \& V Sitters, Revised Pg. 34 \\
\hline 29 & 36 - W Sitters, Revised Pg. 35 \\
\hline 32 & 32 - W Sitters, Revised Pg.36 \\
\hline 37 & $14-$ Y Sitters, Revised Pg. 37 \\
\hline 38 & 37 - [Unidentified] Sitters, Revised Pg. 38 \\
\hline 39 & 39 - [Unidentified] Sitters, Revised Pg. 39 \\
\hline
\end{tabular}




\section{APPENDIX II: Catalogue of Identified Portraits in Disbound Album Pages}

This is a catalogue of all 579 photographs found on the 39 disbound album pages, which have now been organized alphabetically. (The alphabetical order is explained on pages 41-46 of the thesis, and is summarized in Appendix I). Each page of Appendix II represents a single album page, and includes both the recto and verso of the album pages. The first column of the catalogue is the "Album Page Identity Number" inscribed in pencil on the top left hand side of each page, followed by a back/slash and the photograph number (as assigned by the author), which is ordered from the left to right, and from top row to bottom row. In the second column, each photograph's placement on either the recto or verso of the album page is indicated. The third column "Marks" indicates (if found) the inscribed negative number in the photograph. The fourth column records all inscriptions on the album page near or relating to the photograph. In the fifth column, "Corresponding Index Book Entry" the matching "Portrait Sequence Number" and corresponding inscription - usually the name of the sitter(s) - from the index book are listed. The sixth column, "Identifying Match", records the documented portrait that helped identify the sitter in the photographs. The majority of these matches are taken from the William Notman Studio, and the unique series number from the studio that is still used by the McCord Museum is recorded. There are two situations in which the matching portrait is not one by Notman and is not found in the museum's database: 1) a McCord Museum accession number which begins with the letter " $\mathrm{M}$ " for those identifying matches that are not by Notman but are in the McCord Museum's collection; and 2) one identifying match, which was made with a portrait from Library and Archives Canada, a portrait of Thomas White on Album Page \#36, is marked by the LAC's 
database (MIKAN) number. Following the reference number are either "(D)" or "(P)". These indicate the terminology employed by the author to denote a Definite Match (D) or a Probable Match (P) ${ }^{64}$ In cases where the sitter's identity has not been independently confirmed, the designation "Not Confirmed" appears. Lastly, any additional information that further confirms the identity of the sitters is found to the last (seventh) column. This, for the most part, consists of the full names as found in the McCord Museum's database but this also includes published reproductions of the portrait or reference to another publication that aided identification. ${ }^{65}$

\footnotetext{
${ }^{64}$ See section, "Intellectual Organization: Relationship between the Album Pages and Index Book" of the Critical Analysis chapter (Pg. 38 - 42). for the complete methodology for identifying the portraits.

${ }^{65}$ The entries in this column that read, "Borthwick" with an accompanying page number and name reference, J Douglas Borthwick, Montreal, its History with Photographs of Many of it's Principal Citizens, (Drysdale and Co., Stationary and Booksellers: Montreal, 1875).
} 
Album Page \#33, Revised Page 1: Sitters A

\begin{tabular}{|c|c|c|c|c|c|c|}
\hline $\mathbf{P g} / \mathbf{P h}$ & $R / V$ & $\begin{array}{l}\text { Marks } \\
\text { (Neg. \#) }\end{array}$ & Inscriptions & $\begin{array}{c}\text { Corresponding Index Book } \\
\text { Entry }\end{array}$ & Identifying Match & Identifying Information \\
\hline $33 / 1$ & Recto & & & 1 Arthur Prince & $\mathrm{I}-42871.1(\mathrm{D})$ & Arthur William Patrick Albert \\
\hline $33 / 2$ & Recto & & & 2 Arthur Prince & $\mathrm{I}-42871.1(\mathrm{D})$ & $\begin{array}{l}\text { Arthur William Patrick Albert, } \\
\text { Image published in the } \\
\text { Canadian Illustrated News - } \\
1860\end{array}$ \\
\hline $33 / 3$ & Recto & & & 3 Arthur Prince & $\mathrm{I}-42871.1(\mathrm{D})$ & Arthur William Patrick Albert \\
\hline $33 / 4$ & Recto & & & 4 Arthur Prince & $\mathrm{I}-42871.1(\mathrm{D})$ & Arthur William Patrick Albert \\
\hline $33 / 5$ & Recto & & & 5 Arthur Prince & $\mathrm{I}-42871.1(\mathrm{D})$ & Arthur William Patrick Albert \\
\hline $33 / 6$ & Recto & & & 6 Arthur Prince & $\mathrm{I}-42871.1(\mathrm{D})$ & Arthur William Patrick Albert \\
\hline $33 / 7$ & Recto & 34721 & Hugh Allan & 7 Hugh Allan & I-38099.1 (D) & Hugh Allan \\
\hline $33 / 8$ & Recto & & & 8 Hugh Allan & I-38099.1 (D) & Hugh Allan \\
\hline $33 / 9$ & Recto & & & 9 Hugh Allan & I-38099.1 (D) & Hugh Allan \\
\hline $33 / 10$ & Recto & & & 10 Andrew Allan & [Not Confirmed] & \\
\hline $33 / 11$ & Verso & & Char. Alexander & 19 Alexander C. (?) & [Not Confirmed] & \\
\hline $33 / 12$ & Verso & & Char. Alexander & 20 Alexander C. (?) & [Not Confirmed] & \\
\hline $33 / 13$ & Verso & & & 22 Armstrong, Mrs. & [Not Confirmed] & $\begin{array}{l}\text { Sole portrait of woman on } \\
\text { Album page \#33 }\end{array}$ \\
\hline $33 / 14$ & Verso & & $\begin{array}{l}\text { Armstrong } \\
\text { (undertaker?) }\end{array}$ & $\begin{array}{l}23 \text { Geo Armstrong or Armstrong } \\
\text { Wm, 33-4 bk }\end{array}$ & [Not Confirmed] & Same man in $33 / 15$ \\
\hline $33 / 15$ & Verso & & & 24 Geo Armstrong & [Not Confirmed] & Same man in $33 / 14$ \\
\hline $33 / 16$ & Verso & 39514 & & 25 Archibald Gardener, 33-6 bk & [Not Confirmed] & \\
\hline $33 / 17$ & Verso & & & $\begin{array}{l}26 \text { Archibald F \& Workman, 33-7 } \\
\text { bk }\end{array}$ & $\mathrm{I}-14981.1(\mathrm{P})$ & Ed. Archibald \\
\hline $33 / 18$ & Verso & & & 27 Aubeck (?) & [Not Confirmed] & \\
\hline $33 / 19$ & Verso & & Edwin Atwater & 17 Atwater Sr Alderman, 33-9 bk & I-30361.1 (D) & Edwin Atwater \\
\hline $33 / 20$ & Verso & & & 18 Atwater H.W., 33-10 & [Not Confirmed] & \\
\hline
\end{tabular}


Album Page \#17, Revised Page 2: Sitters B

\begin{tabular}{|c|c|c|c|c|c|c|}
\hline $\mathbf{P g} / \mathbf{P h}$ & $\mathbf{R} / \mathbf{V}$ & $\begin{array}{l}\text { Marks } \\
\text { (Neg. \#) }\end{array}$ & Inscriptions & $\begin{array}{c}\text { Corresponding Index Book } \\
\text { Entry }\end{array}$ & Identifying Match & Identifying Information \\
\hline $17 / 1$ & Recto & & & 30 Beckett Powder (?) & $\mathrm{I}-11660.1(\mathrm{P})$ & T. Beckett \\
\hline $17 / 2$ & Recto & & & 31 Bethune Col 17-2 & [Not Confirmed] & \\
\hline $17 / 3$ & Recto & & & 33 Brown Rodiem (?) daughter & [Not Confirmed] & \\
\hline $17 / 4$ & Recto & & Belle & 38 Belle G Agent, 17-4 & [Not Confirmed] & \\
\hline $17 / 5$ & Recto & & & 39 Brush, S. (?) & $\mathrm{I}-1167.1(\mathrm{P})$ & Mr. Brush \\
\hline $17 / 6$ & Recto & & & 40 Bertham firechief & Borthwick pg. 48-49 (D) & Alexander Bertham \\
\hline $17 / 7$ & Recto & & ? Bryson & 41 Bryson Drugs $17-7$ & [Not Confirmed] & \\
\hline $17 / 8$ & Recto & & & 42 Beaudry " & [Not Confirmed] & \\
\hline $17 / 9$ & Recto & & & 43 Bland Rev & $\mathrm{I}-10440.1(\mathrm{P})$ & N. F. Bland \\
\hline $17 / 10$ & Recto & & $\begin{array}{l}\text { ? Browning } \\
\text { (Ottawa Hotel) }\end{array}$ & 44 Browning & $\mathrm{I}-25038.1(\mathrm{D})$ & Col. Browning \\
\hline $17 / 11$ & Verso & & & $\begin{array}{l}45 \text { Beaugrand H. Mayor La } \\
\text { Patrie, } 17-1 \mathrm{bk}\end{array}$ & II-82778 (D) & Mayor Honoré Beaugrand \\
\hline $17 / 12$ & Verso & & & 47 Brown David, 17-2 bk & $\mathrm{I}-5451.1(\mathrm{P})$ & David Brown \\
\hline $17 / 13$ & Verso & & & 48 Brady & I-6261.1 (D) & Fred I. Brady \\
\hline $17 / 14$ & Verso & & & 50 Bernard Dr., 17-4 bk & $\mathrm{I}-86576.1(\mathrm{P})$ & $\begin{array}{l}\text { Mayor Bernard, 1873; same } \\
\text { black leather club chair as } \\
19 / 4\end{array}$ \\
\hline $17 / 15$ & Verso & & & $\begin{array}{l}55 \text { Beem W. G. Dr. (Chief), 9-9, } \\
\text { Lt, 17-5 bk }\end{array}$ & [Not Confirmed] & \\
\hline $17 / 16$ & Verso & & & 54 Bethune S., 17-6 bk & $1-240.1$ (D) & S. Bethune \\
\hline $17 / 17$ & Verso & & & 53 Bethune Mrs., 17-7 bk & $\mathrm{I}-391.1(\mathrm{P})$ & Mrs. Bethune \\
\hline $17 / 18$ & Verso & & & & & [Unidentified Man] \\
\hline $17 / 19$ & Verso & & & 57 Bentley D. & I-8152.1 (D) & David Bentley \\
\hline $17 / 20$ & Verso & & & 62 Benning & I-31523.1 (D) & Mr. Benning \\
\hline
\end{tabular}


Album Page \#19, Revised Page 3: Sitters B

\begin{tabular}{|c|c|c|c|c|c|c|}
\hline $\mathbf{P g} / \mathbf{P h}$ & $\mathbf{R} / \mathbf{V}$ & $\begin{array}{l}\text { Marks } \\
\text { (Neg. \#) }\end{array}$ & Inscriptions & $\begin{array}{l}\text { Corresponding Index Book } \\
\text { Entry }\end{array}$ & Identifying Match & Identifying Information \\
\hline $19 / 1$ & Recto & & & 58 Baillie & I-66894.1 (D) & J. H. Baillie \\
\hline $19 / 2$ & Recto & & & 88 (Brown) " Dunbar, 19-2 & $\mathrm{I}-17892(\mathrm{P})$ & Champion Brown \\
\hline $19 / 3$ & Recto & & & 63 Botterell Revd & $\mathrm{I}-21469.1(\mathrm{D})$ & Rev. E. Botterell \\
\hline $19 / 4$ & Recto & & & 56 Brimner, 19-4 & [Not Confirmed] & \\
\hline $19 / 5$ & Recto & & & 67 Baynes Geo Dr., 9-5 & $\mathrm{I}-47817.1(\mathrm{P})$ & Dr. G. A. Baynes \\
\hline $19 / 6$ & Recto & & & & & [Unidentified Man] \\
\hline $19 / 7$ & Recto & & & & & [Unidentified Man] \\
\hline $19 / 8$ & Recto & & & & & [Unidentified Woman] \\
\hline $19 / 9$ & Recto & & & & & [Unidentified Man] \\
\hline $19 / 10$ & Recto & & & & & [Unidentified Man] \\
\hline $19 / 11$ & Verso & & & 66 Bagg Mrs Lindsay & $\mathrm{I}-19074.1(\mathrm{P})$ & $\begin{array}{l}\text { Mary H. Bagg married to } \\
\text { Robert Lindsay }\end{array}$ \\
\hline
\end{tabular}


Album Page \#9, Revised Page 4, Sitters B

\begin{tabular}{|c|c|c|c|c|c|c|}
\hline $\mathbf{P g} / \mathbf{P h}$ & $\mathbf{R} / \mathbf{V}$ & $\begin{array}{l}\text { Marks } \\
\text { (Neg. \#) }\end{array}$ & Inscriptions & $\begin{array}{c}\text { Corresponding Index Book } \\
\text { Entry }\end{array}$ & Identifying Match & Identifying Information \\
\hline $9 / 1$ & Recto & & & 62 Benning & $\mathrm{I}-31522.1(\mathrm{D})$ & Mr. Benning \\
\hline $9 / 2$ & Recto & & & & & [Unidentified Man] \\
\hline $9 / 3$ & Recto & & & 64 Baker Mrs & $\mathrm{I}-2941.1$ (D) & J. C. Baker \\
\hline $9 / 4$ & Recto & & & & & [Unidentified Woman] \\
\hline $9 / 5$ & Recto & & & & & [Unidentified Man] \\
\hline $9 / 6$ & Recto & & & & & [Unidentified Man] \\
\hline $9 / 7$ & Recto & & & & & [Unidentified Man] \\
\hline $9 / 8$ & Recto & & & & & [Unidentified Man] \\
\hline 9/9 & Recto & & & 71 Brown John Jas, p9-9 & $\mathrm{I}-1170.1(\mathrm{P})$ & J. J. Brown \\
\hline $9 / 10$ & Recto & & & & & [Unidentified Man] \\
\hline $9 / 11$ & Verso & & & & & [Unidentified Man] \\
\hline $9 / 12$ & Verso & & & 74 Burns Dr. & I-3671.1 (Exact Copy) & $\begin{array}{l}\text { Copy of William Notman's } \\
\text { portrait of Doctor Robert } \\
\text { Burns from } 1862 \text { within an } \\
\text { oval vignette. }\end{array}$ \\
\hline $9 / 13$ & Verso & & & & & [Unidentified Man] \\
\hline $9 / 14$ & Verso & & & 76 V Beaudry & $\mathrm{I}-11467.1(\mathrm{P})$ & V. Beaudry \\
\hline $9 / 15$ & Verso & & & 77 Barclay Wm & $\mathrm{I}-25662.1(\mathrm{D})$ & Mr. Barclay \\
\hline $9 / 16$ & Verso & & & 79 Bulmer H Com & I-15872.1 (D) & Henry Bulmer \\
\hline $9 / 17$ & Verso & & & 83 Bourret & I-18964.1 (D) & M. Bourret \\
\hline $9 / 18$ & Verso & & & & & [Unidentified Man] \\
\hline $9 / 19$ & Verso & & & & & [Unidentified Man] \\
\hline $9 / 20$ & Verso & & & 87 Blackwell & $\mathrm{I}-4834.0 .1(\mathrm{P})$ & T. E. Blackwell \\
\hline
\end{tabular}


Album Page \#30, Revised Page 5, Sitters C

\begin{tabular}{|c|c|c|c|c|c|c|}
\hline $\mathbf{P g} / \mathbf{P h}$ & $\mathbf{R} / \mathbf{V}$ & $\begin{array}{l}\text { Marks } \\
\text { (Neg. \#) }\end{array}$ & Inscriptions & $\begin{array}{c}\text { Corresponding Index Book } \\
\text { Entry }\end{array}$ & Identifying Match & Identifying Information \\
\hline $30 / 1$ & Recto & & & 102 Clarke Universal stone [?] & $\mathrm{I}-736.1(\mathrm{P})$ & A. T. Clarke \\
\hline $30 / 2$ & Recto & & & 104 Chapleau Sir, 30-2 & $\mathrm{I}-37057.1(\mathrm{D})$ & $\begin{array}{l}\text { Hon. Joseph Adolphe } \\
\text { Chapleau }\end{array}$ \\
\hline $30 / 3$ & Recto & & & 103 Cushing L & $\mathrm{I}-11130.1(\mathrm{D})$ & Lemuel Cushing \\
\hline $30 / 4$ & Recto & & & $\begin{array}{l}\text { 105 Chiniguay (Chiniguy) Father, } \\
30-4\end{array}$ & II-94546.1 (D) & $\begin{array}{l}\text { Charles Paschal Telesphore } \\
\text { Chiniguy }\end{array}$ \\
\hline $30 / 5$ & Recto & & & 106 Cowie Alex McK & $\mathrm{I}-13125.1$ (D) & A. McK. Cowie \\
\hline $30 / 6$ & Recto & & & 107 Claxton, 30-6 & $\mathrm{I}-6682.1(\mathrm{D})$ & Thomas James Claxton \\
\hline $30 / 7$ & Recto & & & 108 Campbell F. W. Dr. & Borthwick, pg.54-55 (D) & Francis Wayland Campbell \\
\hline $30 / 8$ & Recto & & Cheese & 109 Cheese W. E. & [Not Confirmed] & \\
\hline $30 / 9$ & Recto & & Carter & 110 Carter & $\mathrm{I}-6755.1(\mathrm{D})$ & George Carter \\
\hline $30 / 10$ & Recto & & 50 & 111 Crawford Col, 30-10 & $\mathrm{I}-16368.1(\mathrm{D})$ & $\begin{array}{l}\text { John Molson Crawford. } \\
\text { Identified in Victoria Rifles } \\
\text { composite - MP-1986.21 }\end{array}$ \\
\hline $30 / 11$ & Verso & & & 112 Clackmeyer C Clerk & $\mathrm{I}-2859.1(\mathrm{P})$ & Edward Glackmeyer \\
\hline $30 / 12$ & Verso & & & & & [Unidentified Man] \\
\hline $30 / 13$ & Verso & & & & & [Unidentified Man] \\
\hline $30 / 14$ & Verso & & & & & [Unidentified Man] \\
\hline $30 / 15$ & Verso & & & 116 Cunningham & $\mathrm{I}-18810.1$ & J. W. Cunningham \\
\hline $30 / 16$ & Verso & & & 119 Clare, $30-6$ bk & [Not Confirmed] & \\
\hline $30 / 17$ & Verso & & & 120 Count Jas, 30-7 bk & [Not Confirmed] & \\
\hline $30 / 18$ & Verso & & & & & [Unidentified Man] \\
\hline $30 / 19$ & Verso & & & 122 Cowan Specimins (?) & I-6623.1 (P) & R.C. Cowan \\
\hline $30 / 20$ & Verso & & & & & [Unidentified Man] \\
\hline
\end{tabular}


Album Page \#24, Revised Page 6, Sitters C

\begin{tabular}{|c|c|c|c|c|c|c|}
\hline $\mathbf{P g} / \mathbf{P h}$ & $\mathbf{R} / \mathbf{V}$ & $\begin{array}{l}\text { Marks } \\
\text { (Neg. \#) }\end{array}$ & Inscriptions & $\begin{array}{c}\text { Corresponding Index Book } \\
\text { Entry }\end{array}$ & Identifying Match & Identifying Information \\
\hline $24 / 1$ & Recto & & & 124 Caverhill Tom & I-7269.1 (D) & Mr. Thomas Caverhill \\
\hline $24 / 2$ & Recto & & & 125 Crathern Ja, 24-2 & I-6053.1 (D) & James Crathern \\
\hline $24 / 3$ & Recto & & & 127 Cook, Dr. Quebec & $\mathrm{I}-49621.1(\mathrm{D})$ & Rev. Dr. Cook \\
\hline $24 / 4$ & Recto & & & & & [Unidentified Man] \\
\hline $24 / 5$ & Recto & & & & & [Unidentified Man] \\
\hline $24 / 6$ & Recto & & & & & [Unidentified Man] \\
\hline $24 / 7$ & Recto & & & & & [Unidentified Man] \\
\hline $24 / 8$ & Recto & & & & & [Unidentified Man] \\
\hline $24 / 9$ & Recto & & & & & [Unidentified Man] \\
\hline $24 / 10$ & Recto & & & 134 Curtis Morfil[?] & $\mathrm{I}-5521.0 .1(\mathrm{P})$ & Captain Curtis \\
\hline $24 / 11$ & Verso & & & $\begin{array}{l}\text { 126 Childs, 24-1 [bk?] } \\
\text { /117 Childs Grocer }\end{array}$ & II-24965.1 (P) & George Childs \\
\hline $24 / 12$ & Verso & & & & & [Unidentified Man] \\
\hline $24 / 13$ & Verso & & & 136 Carpenter Mrs, 24-3 bk & [Not Confirmed] & \\
\hline $24 / 14$ & Verso & & & 137 Christie Mrs & $\mathrm{I}-23435$ (D) & Mrs. P. M. Christie \\
\hline $24 / 15$ & Verso & & Jean Baptist Rice & 139 Canadian John Pilot in Rapids & II-50718 (D) & Big John Canadian, Mohawk \\
\hline
\end{tabular}


Album Page \#5, Revised Page 7, Sitters C

\begin{tabular}{|c|c|c|c|c|c|c|}
\hline $\mathbf{P g} / \mathbf{P h}$ & $\mathbf{R} / \mathbf{V}$ & $\begin{array}{l}\text { Marks } \\
\text { (Neg.\#) }\end{array}$ & Inscriptions & $\begin{array}{c}\text { Corresponding Index Book } \\
\text { Entry }\end{array}$ & Identifying Match & Identifying Information \\
\hline $5 / 1$ & Recto & & & & & [Unidentified Man] \\
\hline $5 / 2$ & Recto & & & & & [Unidentified Man] \\
\hline $5 / 3$ & Recto & & & & & [Unidentified Man] \\
\hline $5 / 4$ & Recto & & & 118 Chambers Revd & $\mathrm{I}-32100.1(\mathrm{D})$ & Rev. T. Chambers \\
\hline $5 / 5$ & Recto & & & & & [Unidentified Man] \\
\hline $5 / 6$ & Recto & & Dr. Craik? & & II-96236 (D) & $\begin{array}{l}\text { Dr. Robert Craik, Dean of } \\
\text { Medicine, McGill } \\
\text { University }\end{array}$ \\
\hline $5 / 7$ & Recto & 32179 & & & & [Unidentified Man] \\
\hline $5 / 8$ & Recto & 33556 & & & & [Unidentified Man] \\
\hline $5 / 9$ & Recto & & & & & [Unidentified Man] \\
\hline $5 / 10$ & Recto & & & 130 Coats & & \\
\hline $5 / 11$ & Verso & & & & & [Unidentified Man] \\
\hline $5 / 12$ & Verso & & & & & [Unidentified Man] \\
\hline
\end{tabular}


Album Page \#12, Revised Page 8, Sitters D

\begin{tabular}{|c|c|c|c|c|c|c|}
\hline $\mathbf{P g} / \mathbf{P h}$ & $\mathbf{R} / \mathbf{V}$ & $\begin{array}{l}\text { Marks } \\
(\text { Neg. \#) }\end{array}$ & Inscriptions & $\begin{array}{c}\text { Corresponding Index Book } \\
\text { Entry }\end{array}$ & Identifying Match & Identifying Information \\
\hline $12 / 1$ & Recto & & & 136 Driscoll & $\mathrm{I}-17774.1(\mathrm{D})$ & J. G. R. Driscoll \\
\hline $12 / 2$ & Recto & & & 137 Date Plumber & $\mathrm{I}-6988.1(\mathrm{P})$ & Henry H. Date \\
\hline $12 / 3$ & Recto & & & $\begin{array}{l}\text { 138 Driefus Emmigration } \\
\text { [SIC] Agent }\end{array}$ & [Not Confirmed] & \\
\hline $12 / 4$ & Recto & & & 139 Dillon & I-2645.1 (D) & John Dillon \\
\hline $12 / 5$ & Recto & & & 140 Dillon (") Nephew & $\mathrm{I}-12223.1(\mathrm{P})$ & J.J.J. Dillon \\
\hline $12 / 6$ & Recto & & 141 & 141 Davis Captain (?) & II-40783.1 (P) & John Davis \\
\hline $12 / 7$ & Recto & & $142, \mathrm{M}(?)$ Davis & 142 Davis (") Captain (") (?) & $\mathrm{I}-27064.1(\mathrm{D})$ & M. Davis \\
\hline $12 / 8$ & Recto & & & 143 Davidson thos(?) (tin)(?) & $\mathrm{I}-4838.1(\mathrm{D})$ & D. Davidson \\
\hline $12 / 9$ & Recto & & $\begin{array}{l}\text { 144, St. Donald } \\
\text { (geologist) }\end{array}$ & 144 Donald Geologist & [Not Confirmed] & \\
\hline $12 / 10$ & Recto & & & 145 Dickson & II-23083 (D) & R. A. Dickson \\
\hline $12 / 11$ & Verso & & & 146 Daly Emmigration Agent & II-55492 (D) & J. Daley \\
\hline $12 / 12$ & Verso & & & 147 Dugdale Dr & I-9112.1 (D) & J. J. Dugdale \\
\hline $12 / 13$ & Verso & & 148, Peter Dods & 148 Dods P. D., p12-3 bk & I-6656.1 (D) & P. D. Dods \\
\hline $12 / 14$ & Verso & & & 149 Dutton A. P. & $\mathrm{I}-6150.1(\mathrm{D})$ & A. P. Dutton \\
\hline $12 / 15$ & Verso & & & 150 Dutton & $\mathrm{I}-27397.1(\mathrm{D})$ & Captain Dutton \\
\hline $12 / 16$ & Verso & & & 151 David Alderman & [Not Confirmed] & \\
\hline $12 / 17$ & Verso & & & 152 Dawes J. P. Lachine & II-79807.1 (D) & James P. Dawes \\
\hline $12 / 18$ & Verso & & & 153 De Lisle M Nolan & $\mathrm{I}-409.1(\mathrm{D})$ & M. Nolan De Lisle \\
\hline $12 / 19$ & Verso & & & 154 De Lisle Toronto & $\mathrm{I}-409.1$ (D) & M. Nolan De Lisle \\
\hline $12 / 20$ & Verso & & & & [Not Confirmed] & $\begin{array}{l}\text { Perhaps Ogilive Logbook } \\
\text { pg. O. }\end{array}$ \\
\hline
\end{tabular}


Album Page \#16, Revised Page 9, Sitters D

\begin{tabular}{|c|c|c|c|c|c|c|}
\hline $\mathbf{P g} / \mathbf{P h}$ & $\mathbf{R} / \mathbf{V}$ & $\begin{array}{c}\text { Marks } \\
\text { (Neg. \#) }\end{array}$ & Inscriptions & $\begin{array}{l}\text { Corresponding Index Book } \\
\text { Entry }\end{array}$ & Identifying Match & Identifying Information \\
\hline $16 / 1$ & Recto & & & 156 Darling Jr & $\mathrm{I}-29754.1$ (D) & H. Darling \\
\hline $16 / 2$ & Recto & & & 157 Darling Sr & $\mathrm{I}-13319.1$ (D) & Willliam Darling \\
\hline $16 / 3$ & Recto & & & 158 Denham G & $\mathrm{I}-510.1(\mathrm{D})$ & Mr. Denham \\
\hline $16 / 4$ & Recto & & & 159 Drummond Geo, 16-4 & I-20711.1 (D) & $\begin{array}{l}\text { George Drummond } \\
\text { Redpath }\end{array}$ \\
\hline $16 / 5$ & Recto & & & 160 David Dr. & $\mathrm{I}-34045$ (D) & Dr. David \\
\hline $16 / 6$ & Recto & & & 161 Devlin, 16-6 & II-5076.0 (D) & Bernard Devlin \\
\hline $16 / 7$ & Recto & & & 162 Dyde, $16-7$ & II-5678.1 (D) & Colonel John Dyde \\
\hline $16 / 8$ & Recto & & & 163 Dyde (") J (?) & $\mathrm{I}-33883.1(\mathrm{P})$ & J. S. Dyde \\
\hline $16 / 9$ & Recto & & & 164 De Bellefeuille & I-16083.1 (D) & Major De Bellefeuille \\
\hline $16 / 10$ & Recto & & & 165 DeGruchy(?) Revd + wife & [Not Confirmed] & \\
\hline $16 / 11$ & Verso & & & 166 Douglas John & I-5812.1 (D) & John Douglas \\
\hline $16 / 12$ & Verso & & & 167 David Father & $\mathrm{I}-3845.1(\mathrm{D})$ & Rev. Joseph David \\
\hline $16 / 13$ & Verso & & & 168 Dougal J. R. (witness) & I-1929.1 (D) & $\begin{array}{l}\text { John Dougall, founder of } \\
\text { Montreal Witness }\end{array}$ \\
\hline $16 / 14$ & Verso & & D. Ducharme & $\begin{array}{l}169 \text { Ducharme Dominique } \\
\text { Music, } 16-4 \mathrm{bk}\end{array}$ & I-30935 (D) & $\begin{array}{l}\text { Dominique Ducharme. } \\
\text { Musician }\end{array}$ \\
\hline $16 / 15$ & Verso & & Desaulles & 170 Desaulles L A Honable & I-2323.1 (D) & $\begin{array}{l}\text { Hon. Louis-Antonie } \\
\text { Desaulles, politician }\end{array}$ \\
\hline $16 / 16$ & Verso & & & 171 Dangerfield Mrs(?) & I-10673.0.1 (P) & Miss Dangerfield \\
\hline $16 / 17$ & Verso & & & $\begin{array}{l}173 \text { De Rocheblave Elmire } \\
\text { Miss }\end{array}$ & $\mathrm{I}-1225.1(\mathrm{P})$ & $\begin{array}{l}\text { Miss Elmire De } \\
\text { Rocheblave }\end{array}$ \\
\hline $16 / 18$ & Verso & & & 174 David (") Mrs. & [Not Confirmed] & \\
\hline $16 / 19$ & Verso & & & 175 David M. E. & I-15969 (D) & M. E. David \\
\hline $16 / 20$ & Verso & & $\begin{array}{l}\text { See Notman } \\
\text { James Dakers } \\
5577-\mathrm{I}\end{array}$ & $\begin{array}{l}176 \text { Dakers Mr MrsX } \\
\text { Telegraph(?) }\end{array}$ & $\mathrm{I}-5577.1(\mathrm{D})$ & James Dakers \\
\hline
\end{tabular}


Album Page \#27, Revised Page 10, Sitters D

\begin{tabular}{|l|l|l|l|l|l|l|}
\hline $\mathbf{P g} / \mathbf{P h}$ & $\mathbf{R} / \mathbf{V}$ & $\begin{array}{c}\text { Marks } \\
\text { (Neg.\#) }\end{array}$ & \multicolumn{1}{|c|}{ Inscriptions } & \multicolumn{1}{c|}{$\begin{array}{c}\text { Corresponding Index Book } \\
\text { Entry }\end{array}$} & \multicolumn{1}{|c|}{ Identifying Match } & Identifying Information \\
\hline $27 / 1$ & Recto & & & 177 Dakers (") Mrs. 27-1 & I-5210.1 (D) & Mrs. James Dakers \\
\hline $27 / 2$ & Recto & & & 178 Darcy James & [Not Confirmed] & \\
\hline
\end{tabular}


Album Page \#23, Page 11, Sitters F

\begin{tabular}{|c|c|c|c|c|c|c|}
\hline $\mathbf{P g} / \mathbf{P h}$ & $\mathbf{R} / \mathbf{V}$ & $\begin{array}{l}\text { Marks } \\
(\text { Neg. \#) }\end{array}$ & Inscriptions & $\begin{array}{c}\text { Corresponding Index Book } \\
\text { Entry }\end{array}$ & Identifying Match & Identifying Information \\
\hline $23 / 1$ & Recto & & & 191 Forbes Geo Capta & $\mathrm{I}-30605.1(\mathrm{P})$ & $\begin{array}{l}\text { Capt. Forbes, 78th } \\
\text { Highlanders }\end{array}$ \\
\hline $23 / 2$ & Recto & & & 192 Farlie (?) Miss & [Not Confirmed] & \\
\hline $23 / 3$ & Recto & & & 193 Forbes Son(?) & [Not Confirmed] & \\
\hline $23 / 4$ & Recto & & & 194 Farie Jas & I-43944.1 (D) & James Fairie \\
\hline $23 / 5$ & Recto & & & & & [Unidentified Man] \\
\hline $23 / 6$ & Recto & & & & & [Unidentified Man] \\
\hline $23 / 7$ & Recto & & 350 & 198 Forsyth (") Mrs. & $\mathrm{I}-6367.1(\mathrm{P})$ & \\
\hline $23 / 8$ & Recto & & & 202 Forman John(?) & $\mathrm{I}-17606.1(\mathrm{P})$ & T. C. Forman \\
\hline $23 / 9$ & Recto & & & & & [Unidentified Man] \\
\hline $23 / 10$ & Recto & & $\begin{array}{l}\text { 200, Samuel } \\
\text { Finlay }\end{array}$ & 200 Finlay Se(?), 23-10 & [Not Confirmed] & \\
\hline $23 / 11$ & Verso & & & 203 Ferguson & $\mathrm{I}-20135.0 .1(\mathrm{D})$ & Hon. Adam Fergusson \\
\hline $23 / 12$ & Verso & & & & & [Unidentified Man] \\
\hline $23 / 13$ & Verso & & & & & [Unidentified Man] \\
\hline $23 / 14$ & Verso & & & & & [Unidentified Man] \\
\hline $23 / 15$ & Verso & & & 205 Fairman, 23-5 bk & II-95516.1 (P) & F. Fairman \\
\hline $23 / 16$ & Verso & 59402 & by Inglis & & & [Unidentified Man] \\
\hline
\end{tabular}


Album Page \#15, Revised Page 12, Sitters G

\begin{tabular}{|c|c|c|c|c|c|c|}
\hline $\mathbf{P g} / \mathbf{P h}$ & $R / V$ & $\begin{array}{l}\text { Marks } \\
(\text { Neg. \#) }\end{array}$ & Inscriptions & $\begin{array}{c}\text { Corresponding Index Book } \\
\text { Entry }\end{array}$ & Identifying Match & Identifying Information \\
\hline $15 / 1$ & Recto & & & & & [Unidentified Man] \\
\hline $15 / 2$ & Recto & & & & & [Unidentified Man] \\
\hline $15 / 3$ & Recto & & & & & [Unidentified Man] \\
\hline $15 / 4$ & Recto & & & 220 Greenshields E. B. Jr (?) & $\mathrm{I}-6222.1(\mathrm{D})$ & $\begin{array}{l}\text { Capt E.B. Greenshields } \\
\text { from the Victoria Rifles } \\
\text { Composite MP-1986.21 }\end{array}$ \\
\hline $15 / 5$ & Recto & & & & & [Unidentified Man] \\
\hline $15 / 6$ & Recto & & & 222 Galt Sir Alex, 15-6 & I-19217.1 (D) & $\begin{array}{l}\text { Hon. Alexander Tilloch } \\
\text { Galt, politician }\end{array}$ \\
\hline $15 / 7$ & Recto & & & & & [Unidentified Man] \\
\hline $15 / 8$ & Recto & & & $\begin{array}{l}225 \text { Green Rev } 15-9 \text { [Incorrect } \\
\text { Tentative Locator Inscription] }\end{array}$ & [Not Confirmed] & \\
\hline $15 / 9$ & Recto & & & $\begin{array}{l}224 \text { Greenshields J. M. P. p15- } \\
8 \text { [Incorrect Tentative Locator } \\
\text { Inscription] }\end{array}$ & $\mathrm{I}-3441.1(\mathrm{P})$ & J. B. Greenshields \\
\hline $15 / 10$ & Recto & & & & & [Unidentified Man] \\
\hline $15 / 11$ & Verso & & & & & [Unidentified Man] \\
\hline $15 / 12$ & Verso & & & & & [Unidentified Man] \\
\hline $15 / 13$ & Verso & 29574 & & & & [Unidentified Man] \\
\hline $15 / 14$ & Verso & 56626 & & 213 Gilmour & I.11413.1 (P) & A. Y. Gilmour \\
\hline $15 / 15$ & Verso & 40841 & & & & [Unidentified Man] \\
\hline $15 / 16$ & Verso & & & 207 Gibb Thomas p15-1 bk & $\mathrm{I}-7738.1(\mathrm{P})$ & Thomas N. Gibb \\
\hline $15 / 17$ & Verso & 32290 & & & & [Unidentified Man] \\
\hline $15 / 18$ & Verso & 42798 & & & & [Unidentified Man] \\
\hline $15 / 19$ & Verso & & & & & [Unidentified Man] \\
\hline $15 / 20$ & Verso & & & & & [Unidentified Man] \\
\hline
\end{tabular}


Album Page \#31, Revised Page 13, Sitters G

\begin{tabular}{|c|c|c|c|c|c|c|}
\hline $\mathbf{P g} / \mathbf{P h}$ & $\mathbf{R} / \mathbf{V}$ & $\begin{array}{l}\text { Marks } \\
\text { (Neg. \#) }\end{array}$ & Inscriptions & $\begin{array}{c}\text { Corresponding Index Book } \\
\text { Entry }\end{array}$ & Identifying Match & Identifying Information \\
\hline $31 / 1$ & Recto & & & & & [Unidentified Woman] \\
\hline $31 / 2$ & Recto & & & $\begin{array}{l}234 \text { Galt Mrs. Sr., } 233 \text { Galt(") } \\
\text { Mrs., } 235 \text { Gait (") Mr Galt, } \\
\text { 236 Galt Mrs Raft(") }\end{array}$ & $\mathrm{I}-14770.1$ (D) & $\begin{array}{l}\text { [Group Portrait] Mrs. Galt } \\
\text { Sr., center }\end{array}$ \\
\hline $31 / 3$ & Recto & & & 238 Griffin Mrs. 31-3 & $\mathrm{I}-13517.1$ (D) & Mrs. J. L. Griffin \\
\hline $31 / 4$ & Recto & & & 239 Griffin Mr. & [Not Confirmed] & \\
\hline $31 / 5$ & & & & & & [Blank, No Photo] \\
\hline $31 / 6$ & & & & & & [Blank, No Photo] \\
\hline $31 / 7$ & & & & & & [Blank, No Photo] \\
\hline $31 / 8$ & & & & & & [Blank, No Photo] \\
\hline $31 / 9$ & & & & & & [Blank, No Photo] \\
\hline $31 / 10$ & & & & & & [Blank, No Photo] \\
\hline $31 / 11$ & Verso & & & & & [Unidentified Man] \\
\hline $31 / 12$ & Verso & & & 227 Gibson Revd & I-14576.1 & Rev. J. M. Gibson \\
\hline $31 / 13$ & Verso & & & & & [Unidentified Man] \\
\hline $31 / 14$ & Verso & & & & & [Unidentified Man] \\
\hline $31 / 15$ & Verso & & & & & [Unidentified Man] \\
\hline $31 / 16$ & Verso & & & & & [Unidentified Man] \\
\hline $31 / 17$ & Verso & & & & & [Unidentified Man] \\
\hline $31 / 18$ & Verso & & & & & [Unidentified Man] \\
\hline $31 / 19$ & Verso & & & & & [Unidentified Man] \\
\hline $31 / 20$ & Verso & & & & & [Unidentified Man] \\
\hline
\end{tabular}


Album Page \#3, Revised Page 14, Sitters G

\begin{tabular}{|l|l|l|l|l|l|l|}
\hline $\mathbf{P g} / \mathbf{P h}$ & $\mathbf{R} / \mathbf{V}$ & $\begin{array}{c}\text { Marks } \\
\text { (Neg. \#) }\end{array}$ & Inscriptions & $\begin{array}{c}\text { Corresponding Index Book } \\
\text { Entry }\end{array}$ & \multicolumn{1}{|c|}{ Identifying Match } & \multicolumn{1}{|l|}{ Identifying Information } \\
\hline $3 / 1$ & Recto & & & & & [Unidentified Woman] \\
\hline $3 / 2$ & Recto & & & & & [Unidentified Man] \\
\hline $3 / 3$ & Recto & & & & & [Unidentified Woman ] \\
\hline $3 / 4$ & Recto & & & & & [Unidentified Man] \\
\hline $3 / 5$ & Recto & & & & [Not Confirmed] & [Unidentified Woman ] \\
\hline $3 / 6$ & Recto & & & 389 Matthewson J. A. 3-6 & \\
\hline $3 / 7$ & Recto & & & 390 Matthewson Wm. & [Not Confirmed] & \\
\hline $3 / 8$ & Recto & & & 231 Geddes (") Mrs. & I-10954 (P) & Mrs. Charles Geddes \\
\hline $3 / 9$ & Recto & & & & & [Unidentified Man] \\
\hline $3 / 10$ & Recto & & & & & \\
\hline $3 / 11$ & Verso & & & & & [Unidentified Man] \\
\hline
\end{tabular}


Album Page \#18, Revised Page 15, Sitters H

\begin{tabular}{|c|c|c|c|c|c|c|}
\hline $\mathbf{P g} / \mathbf{P h}$ & $R / V$ & $\begin{array}{l}\text { Marks } \\
\text { (Neg. \#) }\end{array}$ & Inscriptions & $\begin{array}{c}\text { Corresponding Index Book } \\
\text { Entry }\end{array}$ & Identifying Match & Identifying Information \\
\hline $18 / 1$ & Recto & & & & & [Unidentified Man] \\
\hline $18 / 2$ & Recto & & & 257 Hunter Jas & I-7922.1 (D) & J. S. Hunter \\
\hline $18 / 3$ & Recto & & & & & [Unidentified Man] \\
\hline $18 / 4$ & Recto & & & $\begin{array}{l}256 \text { Howard Harbour Master } \\
18-4\end{array}$ & I-1206.1 (D) & Capt. Howard \\
\hline $18 / 5$ & Recto & & & 255 Henshaw /lame/ & I-116.1 (D) & Mr. Henshaw \\
\hline $18 / 6$ & Recto & & & 253 Howie Ald (?) & $\mathrm{I}-32096.1(\mathrm{P})$ & Sergeant Howie \\
\hline $18 / 7$ & Recto & & & 252 Hogan Henry 18-7 & $\mathrm{I}-2016.1$ (D) & Mr. Hogan \\
\hline $18 / 8$ & Recto & & & 251 Handyside Col 18-8 & I-67551 (D) & $\begin{array}{l}\text { Major Nathaniel J. } \\
\text { Handyside }\end{array}$ \\
\hline $18 / 9$ & Recto & & & 249 Hutcheson 18-9 & [Not Confirmed] & \\
\hline $18 / 10$ & Recto & & & 258 Hamilton & $\mathrm{I}-31187.1(\mathrm{D})$ & Robert Hamilton \\
\hline $18 / 11$ & Verso & & & $\begin{array}{l}248 \text { Holton Hond H. 17-1(18-1 } \\
\text { bk?) }\end{array}$ & $\mathrm{I}-27912.1(\mathrm{D})$ & Edward Holton \\
\hline $18 / 12$ & Verso & & Harte & 247 Harte J. A. 18-2 bk Drugs & [Not Confirmed] & \\
\hline $18 / 13$ & Verso & & & 246 Hilton Organist & $\mathrm{I}-4657.1(\mathrm{P})$ & John C. Hilton \\
\hline $18 / 14$ & Verso & 38771 & & 245 Harrington Dr. & $\begin{array}{l}\text { II-77336 (P) much older } \\
\text { portrait, younger in this } \\
\text { image }\end{array}$ & $\begin{array}{l}\text { Prof. Dr. Bernard } \\
\text { Harrington }\end{array}$ \\
\hline $18 / 15$ & Verso & & & & & [Unidentified Man] \\
\hline $18 / 16$ & Verso & 35461 & & 242 Haldane J (?) & [Not Confirmed] & \\
\hline $18 / 17$ & Verso & & & 241 Healy & $\mathrm{I}-23624.1(\mathrm{P})$ & Captain Healy \\
\hline $18 / 18$ & Verso & & & 240 Hunt Sterry Dr. $18-8$ bk & $\mathrm{I}-2090.1$ (D) & Sterry Hunt \\
\hline
\end{tabular}


Album Page \#10, Revised Page 16, Sitters H

\begin{tabular}{|c|c|c|c|c|c|c|}
\hline $\mathbf{P g} / \mathbf{P h}$ & $\mathbf{R} / \mathbf{V}$ & $\begin{array}{l}\text { Marks } \\
\text { (Neg. \#) }\end{array}$ & Inscriptions & $\begin{array}{c}\text { Corresponding Index Book } \\
\text { Entry }\end{array}$ & Identifying Match & Identifying Information \\
\hline $10 / 1$ & Recto & & & 280 Hannaford Mrs 10-1 & $\mathrm{I}-25472.1(\mathrm{D})$ & Mrs. Hannaford \\
\hline $10 / 2$ & Recto & & & 278 Holmes Miss & I-5175.1 (D) & Miss George Holmes \\
\hline $10 / 3$ & Recto & & & 281 Hood Mrs & $\mathrm{I}-24485.1(\mathrm{P})$ & Mrs. A. W. Hood \\
\hline $10 / 4$ & Recto & & & & & [Unidentified Man] \\
\hline $10 / 5$ & Recto & & & $\begin{array}{l}276 \text { Holland (") Wm/Mr (?) } \\
10-4 \text { bk }\end{array}$ & $\mathrm{I}-31657.1(\mathrm{P})$ & Mrs. Phillip Holland \\
\hline $10 / 6$ & Recto & & & 275 Hammond Revd + Wife & [Not Confirmed] & \\
\hline $10 / 7$ & Recto & & & 279 Hodgson Miss & II-56690.1 (P) & Miss Hodgson \\
\hline $10 / 8$ & Recto & & & 254 Hooker A.(?) C. & $\mathrm{I}-8866.0 .1(\mathrm{P})$ & General Joe Hooker \\
\hline $10 / 9$ & Recto & & & & & [Unidentified Man] \\
\hline $10 / 10$ & Recto & & & & & [Unidentified Man] \\
\hline $10 / 11$ & Verso & & & 270 Hagar (") Son Wm Hagar & $\mathrm{I}-23310.1(\mathrm{P})$ & William Hagar \\
\hline $10 / 12$ & Verso & & & & & [Unidentified Man] \\
\hline $10 / 13$ & Verso & & $\begin{array}{l}\text { 268, Dr. Wm } \\
\text { Hingston }\end{array}$ & 268 Hingston Sir Wm 10-3bk & $\mathrm{I}-5593(\mathrm{D})$ & $\begin{array}{l}\text { Doctor William Hale } \\
\text { Hingston }\end{array}$ \\
\hline $10 / 14$ & Verso & 38860 & & & & [Unidentified Man] \\
\hline $10 / 15$ & Verso & & & & & [Unidentified Man] \\
\hline $10 / 16$ & Verso & & & & & [Unidentified Man] \\
\hline $10 / 17$ & Verso & & & 264 Hodgson Jonathan 10-7 bk & II-56152.1 (D) & John Hodgson \\
\hline $10 / 18$ & Verso & & & 269 Hagar & $\mathrm{I}-42837.1(\mathrm{D})$ & C. W. Hagar \\
\hline $10 / 19$ & Verso & & & 261 Hinks & $\mathrm{I}-26872.0 .1(\mathrm{P})$ & Governor Francis Hinks \\
\hline $10 / 20$ & Verso & & & 260 or $243(?)$ & $\mathrm{I}-41060.1$ (D) & Fred Hart \\
\hline
\end{tabular}


Album Page \#6, Revised Page 17, Sitters J \& K

\begin{tabular}{|c|c|c|c|c|c|c|}
\hline $\mathbf{P g} / \mathbf{P h}$ & $\mathbf{R} / \mathbf{V}$ & $\begin{array}{l}\text { Marks } \\
(\text { Neg.\#) }\end{array}$ & Inscriptions & $\begin{array}{c}\text { Corresponding Index Book } \\
\text { Entry }\end{array}$ & Identifying Match & Identifying Information \\
\hline $6 / 1$ & Recto & & & 292 Jacques Jr p6-1 & $\mathrm{I}-19245.1(\mathrm{P})$ & J. E. Jacques Jr \\
\hline $6 / 2$ & Recto & & 125 & 288 Jenkins John Revd p6-2 & $\mathrm{I}-24052.1$ (D) & Rev. Dr. Jenkins \\
\hline $6 / 3$ & Recto & & & 289 Chief Joseph p6-3 & [Not Confirmed] & \\
\hline $6 / 4$ & Recto & & & 290 Chief Joseph (") wife p6-4 & [Not Confirmed] & \\
\hline $6 / 5$ & Recto & & & Johnson F??? Sir p6-5 & II-64083.1 (D) & Judge Johnson \\
\hline $6 / 6$ & Recto & & & 293 Jordan Baths & $\mathrm{I}-12212.1(\mathrm{P})$ & Francis Jordan \\
\hline $6 / 7$ & Recto & & & & & [Unidentified Man] \\
\hline $6 / 8$ & Recto & & & & & [Unidentified Man] \\
\hline $6 / 9$ & Recto & & & 295 Joyce Alfred p6-9 & I-20459.1 (D) & Alf Joyce \\
\hline $6 / 10$ & Recto & 32954 & & 296 Jones Jr & II-76212.1 (D) & F. Jones \\
\hline $6 / 11$ & Verso & & & 297 Kennedy & I-7489.1 (P) & John Kennedy \\
\hline $6 / 12$ & Verso & & & $\begin{array}{l}298 \text { Kershaw Broker(?) } \\
\text { McGill }\end{array}$ & I-8689.1 (D) & Thomas Kershaw \\
\hline $6 / 13$ & Verso & & & 302 Kimber & $\mathrm{I}-20717.1(\mathrm{D})$ & R. Kimber \\
\hline $6 / 14$ & Verso & & & & & [Unidentified Man] \\
\hline $6 / 15$ & Verso & & & & & [Unidentified Man] \\
\hline $6 / 16$ & Verso & & & & & [Unidentified Man] \\
\hline $6 / 17$ & Verso & & & 303 King Col & Not Confirmed] & \\
\hline
\end{tabular}


Album Page \#38, Revised Page 18, Sitters K

\begin{tabular}{|l|l|l|l|l|l|l|}
\hline $\mathbf{P g} / \mathbf{P h}$ & $\mathbf{R} / \mathbf{V}$ & $\begin{array}{c}\text { Marks } \\
\text { (Neg. \#) }\end{array}$ & \multicolumn{1}{|c|}{ Inscriptions } & $\begin{array}{c}\text { Corresponding Index Book } \\
\text { Entry }\end{array}$ & \multicolumn{1}{|c|}{ Identifying Match } & \multicolumn{1}{|c|}{ Identifying Information } \\
\hline $38 / 1$ & Recto & & & 304 Kay Fred 38-1 & I-8640.1 (D) & W. F. Kay \\
\hline $38 / 2$ & Recto & & & 305 Kay Fred 38-2 & I-8640.1 (D) & W. F. Kay \\
\hline $38 / 3$ & Recto & & & & & [Unidentified Man] \\
\hline $38 / 4$ & Recto & & & 307 Knox 38-4 drugs & II-80278.1 (P) & J. H. Knox \\
\hline $38 / 5$ & Recto & & & 308 Kirkhouse 38-5 powder(?) & [Not Confirmed] & \\
\hline
\end{tabular}


Album Page \#2, Revised Page 19, Sitters L

\begin{tabular}{|c|c|c|c|c|c|c|}
\hline $\mathbf{P g} / \mathbf{P h}$ & $R / V$ & $\begin{array}{l}\text { Marks } \\
\text { (Neg.\#) }\end{array}$ & Inscriptions & $\begin{array}{c}\text { Corresponding Index Book } \\
\text { Entry }\end{array}$ & Identifying Match & Identifying Information \\
\hline $2 / 1$ & Recto & & & & & [Unidentified Man] \\
\hline $2 / 2$ & Recto & & & & & [Unidentified Man] \\
\hline $2 / 3$ & Recto & & & 311 Lavender & II-64684 (P) & H. Lavender \\
\hline $2 / 4$ & Recto & & & 312 Lyman H. p2-4 & I-1003.1 (D) & Henry Lyman \\
\hline $2 / 5$ & Recto & & & 313 Lyman (") H. Mrs. & I-16531.1 (D) & Mrs. Henry Lyman \\
\hline $2 / 6$ & Recto & 38051 & & 314 Leggatt booty(??) & $\mathrm{I}-26750.1(\mathrm{P})$ & James Leggatt \\
\hline $2 / 7$ & Recto & & & 315 Lovell Mr \& Mrs p2-7 & $\begin{array}{l}\mathrm{I}-19133.1 \& \mathrm{I}-16683.1 \\
\text { (D) }\end{array}$ & $\begin{array}{l}\text { Mr John Lovell \& Mrs. } \\
\text { Lovell (née Sarah Kurczyn) }\end{array}$ \\
\hline $2 / 8$ & Recto & & & 316 Linton & $\mathrm{I}-4460.1(\mathrm{D})$ & James Linton \\
\hline $2 / 9$ & Recto & & & 317 Lundy & $\mathrm{I}-1580.1(\mathrm{P})$ & Dr. Lundy \\
\hline $2 / 10$ & Recto & & & & & [Unidentified Man] \\
\hline $2 / 11$ & Verso & 58858 & & & & [Unidentified Man] \\
\hline $2 / 12$ & Verso & & & $\begin{array}{l}320 \text { Lloyd Richmond?? } \\
\text { Laundry? }\end{array}$ & $\mathrm{I}-10089.1(\mathrm{P})$ & John G. Lloyd \\
\hline $2 / 13$ & Verso & & $\begin{array}{l}\text { 321, Rev T. } \\
\text { Lafleur }\end{array}$ & 321 Lafleur Revd & I-67993.1 (D) & Reverend Theodore Lafleur \\
\hline $2 / 14$ & Verso & & $\begin{array}{l}322, \text { Lowe (?) } \\
\text { Negro }\end{array}$ & 322 Lowe (?) Ann Negro & [Not Confirmed] & \\
\hline $2 / 15$ & Verso & & & & & [Unidentified Man] \\
\hline $2 / 16$ & Verso & & Lonsdale & 324 Lonsdale & I-5142.1 (D) & R. J. Lonsdale \\
\hline $2 / 17$ & Verso & & & 325 Laclaire Lancaster & $\mathrm{I}-20342.1(\mathrm{D})$ & A. C. Leclair \\
\hline $2 / 18$ & Verso & & $\begin{array}{l}\text { 326, W. } \\
\text { Lockerby }\end{array}$ & 326 Lockerby W. W. & [Not Confirmed] & \\
\hline $2 / 19$ & Verso & 64540 & $\begin{array}{l}\text { 327, Hon. } \\
\text { Laviolette }\end{array}$ & 327 Laviolette Honble & II-64128.1 (D) & Godfrey Laviolette \\
\hline $2 / 20$ & Verso & & $\begin{array}{l}\text { 328, J. B. } \\
\text { Learmont }\end{array}$ & 328 Learmont J. B. & I-10984.1 (D) & Joseph B. Learmont \\
\hline
\end{tabular}


Album Page \#20, Revised Page 20, Sitters M

\begin{tabular}{|c|c|c|c|c|c|c|}
\hline $\mathbf{P g} / \mathbf{P h}$ & $R / V$ & $\begin{array}{l}\text { Marks } \\
\text { (Neg. \#) }\end{array}$ & Inscriptions & $\begin{array}{c}\text { Corresponding Index Book } \\
\text { Entry }\end{array}$ & Identifying Match & Identifying Information \\
\hline $20 / 1$ & Recto & & & & & [Unidentified Man] \\
\hline $20 / 2$ & Recto & & & & & [Unidentified Man] \\
\hline $20 / 3$ & Recto & & & & & $\begin{array}{l}\text { George Stephens, Lord } \\
\text { Mount Stephens }\end{array}$ \\
\hline $20 / 4$ & Recto & & & 368 Millar 20-4 & $\mathrm{I}-117.1(\mathrm{P})$ & Lt. Millar \\
\hline $20 / 5$ & Recto & & H. Morgan & 342 Morgan Henry D. G. 20-5 & MP-1991.21 (EXACT) & Henry Morgan \\
\hline $20 / 6$ & Recto & & & & & [Unidentified Man] \\
\hline $20 / 7$ & Recto & & & & & [Unidentified Man] \\
\hline $20 / 8$ & Recto & & & & & [Unidentified Man] \\
\hline $20 / 9$ & Recto & & & 347 Morrison Jas & I-1446.1 (D) & Mr. James Morrison \\
\hline $20 / 10$ & Recto & & & 348 Moir & I-11416.1 (P) & J. A. Moir \\
\hline $20 / 11$ & Verso & & & & & [Unidentified Man] \\
\hline $20 / 12$ & Verso & & & & & [Unidentified Man] \\
\hline $20 / 13$ & Verso & & & Marler W de M 20-3bk & $\mathrm{I}-32729.1(\mathrm{P})$ & W. H. Marler \\
\hline $20 / 14$ & Verso & & & & & [Unidentified Man] \\
\hline $20 / 15$ & Verso & & & & & [Unidentified Man] \\
\hline $20 / 16$ & Verso & & & 356 Moore T. S. & I-30303.1 (D) & Thomas S. Moore \\
\hline $20 / 17$ & Verso & & & 357 Moore T. S. Jr & I-8945.1 (D) & Thomas S. Moore Jr. \\
\hline $20 / 18$ & Verso & & & 358 Massey Revd & II-67840.1 (D) & Rev. Samuel Massey \\
\hline $20 / 19$ & Verso & & & 359 Morland Thos & I-7981.1 (D) & Thomas Morland \\
\hline $20 / 20$ & Verso & & & 360 Morris Alex Honble & $\mathrm{I}-3052.1(\mathrm{P})$ & Rev J. Alex Morris \\
\hline
\end{tabular}


Album Page \#35, Revised Page 21, Sitters M

\begin{tabular}{|c|c|c|c|c|c|c|}
\hline $\mathbf{P g} / \mathbf{P h}$ & $\mathbf{R} / \mathbf{V}$ & $\begin{array}{l}\text { Marks } \\
(\text { Neg. \#) }\end{array}$ & Inscriptions & \begin{tabular}{|c|} 
Corresponding Index Book \\
Entry
\end{tabular} & Identifying Match & Identifying Information \\
\hline $35 / 1$ & Recto & & 361, David & $\begin{array}{l}361 \text { Morrice David Bott(?) 35- } \\
1\end{array}$ & I-17739.1 (D) & David Morrice \\
\hline $35 / 2$ & Recto & & $\begin{array}{l}\text { 362, Rev. Dr. } \\
\text { Matherson }\end{array}$ & $\begin{array}{l}362 \text { Mathewson (Mathieson) } \\
\text { Alex Dr., 35-2 }\end{array}$ & $\begin{array}{l}\text { I-15846.1 (EXACT) - } \\
\text { Copy of Notman Portrait } \\
\text { in Oval Frame }\end{array}$ & $\begin{array}{l}\text { Rev. Dr. Alexander } \\
\text { Mathieson }\end{array}$ \\
\hline $35 / 3$ & Recto & & $\begin{array}{l}\text { 363, Din(??) } \\
\text { Masson }\end{array}$ & & [Not Confirmed] & \\
\hline $35 / 4$ & Recto & & $\begin{array}{l}\text { 364, Robt } \\
\text { Mackay }\end{array}$ & 364 Mackay R 35-4 & $\mathrm{I}-24845.1$ (D) & Robert Mackay \\
\hline $35 / 5$ & Recto & & & 365 Morris Jr saddles(?) & $\mathrm{I}-14416.1(\mathrm{P})$ & John L. Morris (?) \\
\hline $35 / 6$ & Recto & & & & & [Unidentified Man] \\
\hline $35 / 7$ & Recto & & & 369 Muir Wm (Macro) (?) & $\mathrm{I}-5551.1(\mathrm{P})$ & William Muir \\
\hline $35 / 8$ & Recto & & & 370 Muir Jr. & II-79578.1 (P) & J. M. C. Muir \\
\hline $35 / 9$ & Recto & & & 371 Macfarlane W. T. & $\mathrm{I}-47144.1(\mathrm{P})$ & \\
\hline $35 / 10$ & Recto & & Wm Maltby & 372 Maltby $35-10$ & $\mathrm{I}-31363.1(\mathrm{D})$ & \\
\hline $35 / 11$ & Verso & & & & & [Unidentified Man] \\
\hline $35 / 12$ & Verso & & & 374 Moss young & II-22906.1 (D) & S. Moss \\
\hline $35 / 13$ & Verso & & & 375 Martin photo & $\mathrm{I}-2231.1(\mathrm{P})$ & Mr. Martin \\
\hline $35 / 14$ & Verso & & & 376 Munroe & $\mathrm{I}-8533.1(\mathrm{P})$ & Alex Munroe \\
\hline $35 / 15$ & Verso & & & & & [Unidentified Man] \\
\hline $35 / 16$ & Verso & 33540 & & $\begin{array}{l}358 \text { Massey Revd } 379 \text { Murphy } \\
\text { J }\end{array}$ & $\begin{array}{l}\text { II-67840.1 (P), II- } \\
79467.1(\mathrm{P})\end{array}$ & $\begin{array}{l}\text { Mr. Rev. Massey John } \\
\text { Murphy }\end{array}$ \\
\hline $35 / 17$ & Verso & & & $\begin{array}{l}380 \text { Muir Major Jas 35-6bk } \\
\text { (wrong) }\end{array}$ & $\mathrm{I}-16643.1(\mathrm{D})$ & Lt. James Muir \\
\hline $35 / 18$ & Verso & & & 381 Macfarlane A & II-76051.1 (D) & Andrew Macfarlane \\
\hline $35 / 19$ & Verso & & & 382 Macfarlane A Mrs & $\mathrm{I}-20275.1$ (D) & Mrs. Andrew Macfarlane \\
\hline $35 / 20$ & Verso & & & 383 Mackay Joseph & I-62917.1 (D) & Mr. Joseph MacKay \\
\hline
\end{tabular}


Album Page \#7, Revised Page 22, Sitters Mc

\begin{tabular}{|c|c|c|c|c|c|c|}
\hline $\mathbf{P g} / \mathbf{P h}$ & $R / V$ & $\begin{array}{l}\text { Marks } \\
(\text { Neg. \#) }\end{array}$ & Inscriptions & $\begin{array}{l}\text { Corresponding Index Book } \\
\text { Entry }\end{array}$ & Identifying Match & Identifying Information \\
\hline $7 / 1$ & Recto & & & & & [Unidentified Man] \\
\hline $7 / 2$ & Recto & & & 396 McPherson Col & $\mathrm{I}-47258.1(\mathrm{D})$ & Colonel McPherson \\
\hline $7 / 3$ & Recto & & & 397 McGibbon Ranger & I-6751.1 (D) & William McGibbon \\
\hline $7 / 4$ & Recto & & & 398 McLaren Jas & II-60690.1 (P) & J. J. McLaren \\
\hline $7 / 5$ & Recto & & & & & [Unidentified Man] \\
\hline $7 / 6$ & Recto & & 400 & 400 McAdam C. & $\mathrm{I}-14323.1$ (D) & C. McAdam \\
\hline $7 / 7$ & Recto & & & & & [Unidentified Man] \\
\hline $7 / 8$ & Recto & & & & & [Unidentified Man] \\
\hline $7 / 9$ & Recto & & 100 & 403 McKilligan John Revd & $\mathrm{I}-10224$ (D) & John McKillican \\
\hline $7 / 10$ & Recto & & ? T McKenzie? & 404 McKay Hy Col & I-7092.1 (D) & Henry McKay \\
\hline $7 / 11$ & Verso & & & 405 McGibbon Alex p7-1bk & $\mathrm{I}-4512.1$ (D) & Alex McGibbon \\
\hline $7 / 12$ & Verso & & & 406 McShane Jamie? & II-54846.1 (D) & J. McShane \\
\hline $7 / 13$ & Verso & & & & & [Unidentified Man] \\
\hline $7 / 14$ & Verso & & & & & [Unidentified Man] \\
\hline $7 / 15$ & Verso & & & & & [Unidentified Man] \\
\hline $7 / 16$ & Verso & & & & & [Unidentified Man] \\
\hline $7 / 17$ & Verso & & & & & [Unidentified Man] \\
\hline $7 / 18$ & Verso & & & & & [Unidentified Man] \\
\hline $7 / 19$ & Verso & & & 413 McVicar D. H. & I-4944.1 (D) & Donald H. McVicar \\
\hline $7 / 20$ & Verso & & & & & [Unidentified Man] \\
\hline
\end{tabular}


Album Page \#8, Revised Page 23, Sitters Mc

\begin{tabular}{|l|l|l|l|l|l|l|}
\hline \multicolumn{1}{|c|}{ Pg/Ph } & R/V & $\begin{array}{c}\text { Marks } \\
\text { (Neg. \#) }\end{array}$ & \multicolumn{1}{|c|}{ Inscriptions } & $\begin{array}{c}\text { Corresponding Index Book } \\
\text { Entry }\end{array}$ & \multicolumn{1}{|c|}{ Identifying Match } & Identifying Information \\
\hline $8 / 1$ & Recto & & & & & [Unidentified Man] \\
\hline $8 / 2$ & Recto & & & & & [Unidentified Man] \\
\hline $8 / 3$ & Recto & & & & & \\
\hline $8 / 4$ & Recto & & 418 & 418 McMaster Wm p8-4 & [Not Confirmed] & \\
\hline $8 / 5$ & Recto & & & 419 McMaster Sr. p8-5 & I-4505.1 (P) & Mr. A. K. McMaster \\
\hline $8 / 6$ & Recto & & & 420 McBride John & II-67776.1 (D) & J. D. McBride \\
\hline $8 / 7$ & Recto & & & 421 McLaren J. C. leather & I-16124.1 (D) & J. C. McLaren \\
\hline $8 / 8$ & Recto & & & 422 McDougall D Lorn p8-8 & I-15622.1 (D) & D. Lorn McDougall \\
\hline $8 / 9$ & Recto & & & 423 McDougall J ?? P14-4 & I-8761.1 (D) & John McDougall \\
\hline $8 / 10$ & Recto & & 424 Mrs. John & 424 McDougall J Mrs p8-10 & I-22794.1 (D) & Mrs. John McDougall \\
\hline $8 / 11$ & Verso & & & & & [Unidentified Man] \\
\hline $8 / 12$ & Verso & 37711 & & 426 McKay & I-7092.1 (P) & Henry McKay \\
\hline
\end{tabular}


Album Page \#4, Revised Page 24, Sitters N

\begin{tabular}{|l|l|l|l|l|l|l|}
\hline $\mathbf{P g} / \mathbf{P h}$ & $\mathbf{R} / \mathbf{V}$ & $\begin{array}{c}\text { Marks } \\
\text { (Neg. \#) }\end{array}$ & \multicolumn{1}{|c|}{ Inscriptions } & $\begin{array}{c}\text { Corresponding Index Book } \\
\text { Entry }\end{array}$ & \multicolumn{1}{|c|}{ Identifying Match } & \multicolumn{1}{|c|}{ Identifying Information } \\
\hline $4 / 1$ & Recto & & & 427 Noble p4-1 & I-7878.1 (P) & Captain Noble \\
\hline $4 / 2$ & Recto & & Notman & 428 Notman Jr & I-9506.1 (P) & William Notman \\
\hline $4 / 3$ & Recto & & Peter Nicholson & $\begin{array}{l}\text { 429 Nicholson Peter Guilder } \\
\text { Erskine(?) C. Milled(?) 32-3 }\end{array}$ & II-56347.1 (D) & P. Nicholson \\
\hline $4 / 4$ & Recto & & & 430 Nichol Revd & I-23136.1 (P) & John Nichol \\
\hline $4 / 5$ & Recto & & $\begin{array}{l}\text { Rev Canon } \\
\text { Norman }\end{array}$ & & I-79743.1 (D) & Richard W. Norman \\
\hline $4 / 6$ & Recto & & $\begin{array}{l}432, \text { H. A. } \\
\text { Nelson }\end{array}$ & & [Not Confirmed] & \\
\hline $4 / 7$ & Recto & & $\begin{array}{l}433, \text { Albert } \\
\text { Nelson (x) }\end{array}$ & 432 Nelson Ald(?) & II-79339.1 (P) & Capt T. G. Nelson \\
\hline $4 / 8$ & Recto & 55384 & 434, (?) Nelson & 433 Nelson H. W. top & I-31720.1 (P) & H. W. Nelson \\
\hline
\end{tabular}


Album Page \#11, Revised Page 25, Sitters O

\begin{tabular}{|l|l|l|l|l|l|l|}
\hline \multicolumn{1}{|c|}{$\mathbf{P g} / \mathbf{P h}$} & $\mathbf{R} / \mathbf{V}$ & $\begin{array}{c}\text { Marks } \\
\text { (Neg. \#) }\end{array}$ & \multicolumn{1}{|c|}{ Inscriptions } & $\begin{array}{c}\text { Corresponding Index Book } \\
\text { Entry }\end{array}$ & \multicolumn{1}{|c|}{ Identifying Match } & \multicolumn{1}{|l|}{ Identifying Information } \\
\hline $11 / 1$ & Recto & & & 445 Ogilvie Misses p11-1 & $\begin{array}{c}\text { [Not Confirmed] Only } \\
\text { Women on page }\end{array}$ & \\
\hline $11 / 2$ & Recto & & A. W. Oglivie & 444 Ogilive A. W. p11-2 & [Not Confirmed] & \\
\hline $11 / 3$ & Recto & & John Oglivie & 443 Ogilvie Dead John p11-3 & II-55161.1 (D) & John Ogilvie \\
\hline $11 / 4$ & Recto & & W. W. Oglivie & 442 W. W. Ogilvie p11-4 & I-6921.1 (D) & William Watson Ogilvie \\
\hline $11 / 5$ & Recto & & Bishop Oxenden & 441 Oxenden Bishop p11-5 & II-46270 (D) & Bishop Oxenden \\
\hline $11 / 6$ & Recto & & & & & [Unidentified Man] \\
\hline $11 / 7$ & Recto & & Father O'Farrell & 439 Father O'Farrell & I-27088.1 (D) & Reverend M. O. Farrell \\
\hline $11 / 8$ & Recto & & & $\begin{array}{l}438 \text { Owens Senders M. P.p11- } \\
9\end{array}$ & I-49231.1 (P) & Thomas Owens \\
\hline $11 / 9$ & Recto & & & & & [Unidentified Man] \\
\hline $11 / 10$ & Recto & & & 436 Oswald Wm Lt p11-10 & I-32318.1 (P) & Mr. Oswald \\
\hline $11 / 11$ & Verso & & & 435 Ostell J & II-42096.1 (D) & J. T. Ostell \\
\hline
\end{tabular}


Album Page \#34, Revised Page 26, Sitters P

\begin{tabular}{|c|c|c|c|c|c|c|}
\hline $\mathbf{P g} / \mathbf{P h}$ & $R / V$ & $\begin{array}{l}\text { Marks } \\
(\text { Neg. \#) }\end{array}$ & Inscriptions & $\begin{array}{c}\text { Corresponding Index Book } \\
\text { Entry }\end{array}$ & Identifying Match & Identifying Information \\
\hline $34 / 1$ & Recto & & & & & [Unidentified Man] \\
\hline $34 / 2$ & Recto & & & 447 Prowse Geo R. 34-2 & I-741.1 (D) & George Roger Prowse \\
\hline $34 / 3$ & Recto & & & 448 Prowes Jr. & $\mathrm{I}-4774.1$ (D) & George Fabes Prowes \\
\hline $34 / 4$ & Recto & & & 449 Pitcher Rev & [Not Confirmed] & \\
\hline $34 / 5$ & Recto & & & & & [Unidentified Man] \\
\hline $34 / 6$ & Recto & & 477 & & & [Unidentified Man] \\
\hline $34 / 7$ & Recto & & & 452 Peck Thos 34-7 & I-7387.1 (D) & Thomas Peck Jr. \\
\hline $34 / 8$ & Recto & & & & & [Unidentified Man] \\
\hline $34 / 9$ & Recto & & & & & [Unidentified Man] \\
\hline $34 / 10$ & Recto & & & 455 Pelletier Dr. & $\mathrm{I}-666.1(\mathrm{P})$ & Mr. Pelletier \\
\hline $34 / 11$ & Verso & & & 457 Penton Chief of Police & I-9553.1 (D) & F. W. L. Penton \\
\hline $34 / 12$ & Verso & & & 458 Penn S L Hall (?) & $\mathrm{I}-1330.1(\mathrm{P})$ & Mr. Penn \\
\hline $34 / 13$ & Verso & & & 459 Popham 34-4bk & $\mathrm{I}-10834.1(\mathrm{P})$ & James Popham \\
\hline $34 / 14$ & Verso & & & 460 Parker Murie(?) & $\mathrm{I}-2920.1$ (D) & Mr. A. D. Parker \\
\hline $34 / 15$ & Verso & & & $\begin{array}{l}461 \text { Philips (ink entry more } \\
\text { likely) }\end{array}$ & I-67457.1 (P) & Joseph Philips \\
\hline $34 / 16$ & Verso & & & $\begin{array}{l}462 \text { Packard Air Prince Arthur } \\
\text { (?) }\end{array}$ & [Not Confirmed] & \\
\hline $34 / 17$ & Verso & & & 463 Pringle $34-8 b \mathrm{~b}$ & $\mathrm{I}-5524.1(\mathrm{P})$ & I. F. Pringle \\
\hline $34 / 18$ & Verso & & & & & [Unidentified Man] \\
\hline $34 / 19$ & Verso & & & & & [Unidentified Man] \\
\hline $34 / 20$ & Verso & & & & & [Unidentified Man] \\
\hline
\end{tabular}


Album Page \#28, Revised Page 27, Sitters P

\begin{tabular}{|l|l|l|l|l|l|l|}
\hline \multicolumn{1}{|c|}{ Pg/Ph } & R/V & $\begin{array}{c}\text { Marks } \\
(\text { Neg. \#) }\end{array}$ & \multicolumn{1}{|c|}{ Inscriptions } & \multicolumn{1}{|c|}{$\begin{array}{c}\text { Corresponding Index Book } \\
\text { Entry }\end{array}$} & \multicolumn{1}{|c|}{ Identifying Match } & \multicolumn{1}{|c|}{ Identifying Information } \\
\hline $28 / 1$ & Recto & & & 466 Proctor Miss 28-1 & I-30802.1 (D) & Miss. Proctor \\
\hline $28 / 2$ & Recto & & & 467 Pagnuelo 28-2 & [Not Confirmed] & \\
\hline $28 / 3$ & Recto & & & 468 Philips M \& P 34-4bk & I-32936.1 (P) & Mr. Phillips \\
\hline $28 / 4$ & Recto & & & 469 Porteous & I-29166.1 (P) & J. Porteous \\
\hline $28 / 5$ & Recto & & & 470 Pedlar Etude (?) & I-29833.1 (D) & S. Pedlar \\
\hline
\end{tabular}


Album Page \#26, Revised Page 28, Sitters R

\begin{tabular}{|l|l|l|l|l|l|l|}
\hline Pg/Ph & R/V & $\begin{array}{c}\text { Marks } \\
\text { (Neg. \#) }\end{array}$ & \multicolumn{1}{|c|}{ Inscriptions } & \multicolumn{1}{c|}{$\begin{array}{c}\text { Corresponding Index Book } \\
\text { Entry }\end{array}$} & \multicolumn{1}{|c|}{ Identifying Information } \\
\hline $26 / 1$ & Recto & & & 475 Reynolds & I-9520.1 (P) & Thomas Reynolds \\
\hline $26 / 2$ & Recto & & & 474 Roy Cemetery & I-14584.1 (P) & Alex Roy \\
\hline $26 / 3$ & Recto & & & 473 Reid Robt Marble 26-3 & I-7886.1 (P) & Robert Reid \\
\hline $26 / 4$ & Recto & & & 472 Roberts & I-19395.1 (D) & Thomas M. Roberts \\
\hline $26 / 5$ & Recto & & & 471 Reinhardt Bremner? & [Not Confirmed] & \\
\hline
\end{tabular}


Album Page \#1, Revised Page 29, Sitters R

\begin{tabular}{|c|c|c|c|c|c|c|}
\hline $\mathbf{P g} / \mathbf{P h}$ & $R / V$ & $\begin{array}{l}\text { Marks } \\
(\text { Neg. \#) }\end{array}$ & Inscriptions & $\begin{array}{c}\text { Corresponding Index Book } \\
\text { Entry }\end{array}$ & Identifying Match & Identifying Information \\
\hline $1 / 1$ & Recto & & & & & [Unidentified Man] \\
\hline $1 / 2$ & Recto & & & & & [Unidentified Man] \\
\hline $1 / 3$ & Recto & & & $\begin{array}{l}493 \text { Ross Yeunice? / Ross P. S. } \\
\text { p1-3 }\end{array}$ & $\mathrm{I}-15631.1(\mathrm{D})$ & Phillip S. Ross \\
\hline $1 / 4$ & Recto & & Rosevear(?) & 492 Rosevear & [Not Confirmed] & \\
\hline $1 / 5$ & Recto & & & & & [Unidentified Man] \\
\hline $1 / 6$ & Recto & & & 490 Roy City Lawyer & $\begin{array}{l}\text { Borthwick, Montreal, Its } \\
\text { History P.113-114 (D) }\end{array}$ & \\
\hline $1 / 7$ & Recto & & & & & [Unidentified Man] \\
\hline $1 / 8$ & Recto & & & & & [Unidentified Man] \\
\hline $1 / 9$ & Recto & & & 487 Rankin John p1-9 & $\mathrm{I}-1503.1(\mathrm{P})$ & \\
\hline $1 / 10$ & Recto & & & 486 Roy Dry Goods & $\mathrm{I}-4210.1(\mathrm{P})$ & William Roy \\
\hline $1 / 11$ & Verso & & Ramsay & 485 Ramsay Mrs & $\begin{array}{l}\text { [Not Confirmed], Only } \\
\text { woman on page }\end{array}$ & \\
\hline $1 / 12$ & Verso & & Wm Robb & 484 Robb Wm & I-3523.1 (D) & William Robb \\
\hline $1 / 13$ & Verso & & Rob & $\begin{array}{l}483 \text { Robertson Sar Lead Morts } \\
\text { ??? }\end{array}$ & I-5604.1 (P) & James Robertson \\
\hline $1 / 14$ & Verso & & & & & [Unidentified Man] \\
\hline $1 / 15$ & Verso & & Rutherford & 481 Rutherford Carpenter & $\mathrm{I}-32206.1(\mathrm{P})$ & George Rutherford \\
\hline $1 / 16$ & Verso & & & 480 Robertson Lawyer & I-1017.1 (D) & William Robertson \\
\hline $1 / 17$ & Verso & & & & [Not Confirmed] & \\
\hline $1 / 18$ & Verso & & & 478 Routh Jr & $\mathrm{I}-5219.1$ (D) & John Routh \\
\hline $1 / 19$ & Verso & & & 477 Routh Sr & $\mathrm{I}-5215.1(\mathrm{D})$ & $\begin{array}{l}\text { Lt. Col. Haviland } \\
\text { Lemessurier Routh }\end{array}$ \\
\hline $1 / 20$ & Verso & & & 476 Ross Donald & II-41996.1 (D) & Donald Ross \\
\hline
\end{tabular}


Album Page \#22, Revised Page 30, Sitters S

\begin{tabular}{|c|c|c|c|c|c|c|}
\hline $\mathbf{P g} / \mathbf{P h}$ & $\mathbf{R} / \mathbf{V}$ & $\begin{array}{l}\text { Marks } \\
(\text { Neg. \#) }\end{array}$ & Inscriptions & $\begin{array}{c}\text { Corresponding Index Book } \\
\text { Entry }\end{array}$ & Identifying Match & Identifying Information \\
\hline $22 / 1$ & Recto & & & & & [Unidentified Man] \\
\hline $22 / 2$ & Recto & & & & & [Unidentified Man] \\
\hline $22 / 3$ & Recto & & & 521 Simpson & $\mathrm{I}-3353.1(\mathrm{D})$ & Thomas Simpson \\
\hline $22 / 4$ & Recto & & & 519 Strathy Gordon 22-4 & $\mathrm{I}-22343.1$ (D) & Ed. W. Strathy \\
\hline $22 / 5$ & Recto & & & & & [Unidentified Man] \\
\hline $22 / 6$ & Recto & 34358 & & 517 Sharpley Mrs. 22-6 & [Not Confirmed] & \\
\hline $22 / 7$ & Recto & & & 520 Skelton $22-1 \mathrm{bk}$ & I-30265.1 (D) & J. W. Skelton \\
\hline $22 / 8$ & Recto & & & $\begin{array}{l}516 \text { Steward Herald \& faurice } \\
\text { (?) } 22-8\end{array}$ & [Not Confirmed] & \\
\hline $22 / 9$ & Recto & & & & & [Unidentified Man] \\
\hline $22 / 10$ & Recto & & & & & [Unidentified Man] \\
\hline $22 / 11$ & Verso & & & 513 Shelton & I-17978.1 (D) & E. E. Shelton \\
\hline $22 / 12$ & Verso & & & 512 Scott Wm Picture 22-2bk & [Not Confirmed] & \\
\hline $22 / 13$ & Verso & & & & & [Unidentified Man] \\
\hline $22 / 14$ & Verso & & & 510 Smardon & [Not Confirmed] & \\
\hline $22 / 15$ & Verso & & & 509 Starnes Honble & $\mathrm{I}-20688.1$ (D) & Hon. Henry Starnes \\
\hline $22 / 16$ & Verso & & & 508 Sterling John 22-7 & $\mathrm{I}-27801.1(\mathrm{D})$ & Mr. J. Sterling \\
\hline $22 / 17$ & Verso & & & & & [Unidentified Man] \\
\hline $22 / 18$ & Verso & & & 515 Stephens Romeo 22-7bk & $\mathrm{I}-26298.1(\mathrm{P})$ & Romeo Stephens, \\
\hline $22 / 19$ & Verso & 35079 & & & & [Unidentified Man] \\
\hline $22 / 20$ & Verso & 29522 & & & & [Unidentified Man] \\
\hline
\end{tabular}


Album Page \#21, Revised Page 31, Sitters S

\begin{tabular}{|c|c|c|c|c|c|c|}
\hline $\mathbf{P g} / \mathbf{P h}$ & $R / V$ & $\begin{array}{l}\text { Marks } \\
(\text { Neg. \#) }\end{array}$ & Inscriptions & $\begin{array}{c}\text { Corresponding Index Book } \\
\text { Entry }\end{array}$ & Identifying Match & Identifying Information \\
\hline $21 / 1$ & Recto & & & & & [Unidentified Man] \\
\hline $21 / 2$ & Recto & & & & & [Unidentified Man] \\
\hline $21 / 3$ & Recto & & & & & [Unidentified Man] \\
\hline $21 / 4$ & Recto & & & & & [Unidentified Man] \\
\hline $21 / 5$ & Recto & & & & & [Unidentified Woman] \\
\hline $21 / 6$ & Recto & & & & & $\begin{array}{l}\text { [Unidentified Man \& } \\
\text { Child] }\end{array}$ \\
\hline $21 / 7$ & Recto & & & & & [Unidentified Man] \\
\hline $21 / 8$ & Recto & & & & & [Unidentified Man] \\
\hline $21 / 9$ & Recto & & & & & [Unidentified Woman] \\
\hline $21 / 10$ & Recto & & & 534 Sutherland Dr. 21-10 & $\mathrm{I}-230.1$ (D) & Dr. Sutherland \\
\hline $21 / 11$ & Verso & & & 533 Swaill Mr \& Mrs & [Not Confirmed] & \\
\hline $21 / 12$ & Verso & & & 532 Swail Wm & [Not Confirmed] & \\
\hline $21 / 13$ & Verso & & & $531 \mathrm{~S} ? ? ? ? ? \mathrm{Mrs}$ & [Not Confirmed] & \\
\hline $21 / 14$ & Verso & & & & & [Unidentified Man] \\
\hline $21 / 15$ & Verso & 32886 & & 529 Slack Revd & $\mathrm{I}-2426.1(\mathrm{D})$ & Rev. Mr. Slack, \\
\hline $21 / 16$ & Verso & & & 528 Stafford Revd & II-65372.1 (D) & Reverend C. A. Stafford \\
\hline $21 / 17$ & Verso & & & 527 Stephens Willie 21-7 & $\mathrm{I}-6853.1(\mathrm{P})$ & $\begin{array}{l}\text { George Washington } \\
\text { Stephens }\end{array}$ \\
\hline $21 / 18$ & Verso & & & $\begin{array}{l}525 \text { Scott Gilbert /Dome?/ 21- } \\
8 \mathrm{bk}\end{array}$ & $\mathrm{I}-10433.1(\mathrm{D})$ & Gilbert Scott \\
\hline $21 / 19$ & Verso & & & & & [Unidentified Man] \\
\hline $21 / 20$ & Verso & & & & & [Unidentified Man] \\
\hline
\end{tabular}


Album Page \#25, Revised Page 32, Sitters S

\begin{tabular}{|l|l|l|l|l|l|l|}
\hline $\mathbf{P g} / \mathbf{P h}$ & $\mathbf{R} / \mathbf{V}$ & $\begin{array}{c}\text { Marks } \\
\text { (Neg. \#) }\end{array}$ & Inscriptions & $\begin{array}{c}\text { Corresponding Index Book } \\
\text { Entry }\end{array}$ & Identifying Match & Identifying Information \\
\hline $25 / 1$ & Recto & & & & & [Unidentified Man] \\
\hline $25 / 2$ & Recto & & & & & [Unidentified Man] \\
\hline $25 / 3$ & Recto & & & & & [Unidentified Man] \\
\hline $25 / 4$ & Recto & & & & & [Unidentified Man] \\
\hline $25 / 5$ & Recto & & & & & [Unidentified Woman] \\
\hline $25 / 6$ & Recto & & & & & [Unidentified Woman] \\
\hline $25 / 6$ & Recto & & & & & [Unidentified Man] \\
\hline $25 / 7$ & Recto & & & & & [Unidentified Man] \\
\hline $25 / 8$ & Recto & & 523 Stevenson & 523 Stevenson Eye? Capt 25-8 & I-29873.1 (P) & $\begin{array}{l}\text { Officer of Montreal Fire } \\
\text { Brigade }\end{array}$ \\
\hline
\end{tabular}


Album Page \#13, Revised Page 33, Sitters T

\begin{tabular}{|c|c|c|c|c|c|c|}
\hline $\mathbf{P g} / \mathbf{P h}$ & $\mathbf{R} / \mathbf{V}$ & $\begin{array}{l}\text { Marks } \\
\text { (Neg. \#) }\end{array}$ & Inscriptions & $\begin{array}{c}\text { Corresponding Index Book } \\
\text { Entry }\end{array}$ & Identifying Match & Identifying Information \\
\hline $13 / 1$ & Recto & & $\begin{array}{l}\text { 561, Percival } \\
\text { Tibbs }\end{array}$ & 561 Tibbs Percival p13-1 & [Not Confirmed] & \\
\hline $13 / 2$ & Recto & & & 560 Tylee $\mathrm{Sr}(?)$ p13-2 & $\mathrm{I}-12208.1(\mathrm{D})$ & Charles D. Tylee \\
\hline $13 / 3$ & Recto & & $\begin{array}{l}559, \text { Homer } \\
\text { Taylor }\end{array}$ & 559 Taylor Homer & MP-1986.21 (D) & $\begin{array}{l}\text { Taylor Homer, Identified in } \\
\text { Victoria Rifles Composite }\end{array}$ \\
\hline $13 / 4$ & Recto & & $558, \mathrm{Tabb}$ & $558 \mathrm{Tabb}$ & I-9844.1 (P) & $\begin{array}{l}\text { W. R. Tabb. Possibly same } \\
\text { man in } 13 / 17\end{array}$ \\
\hline $13 / 5$ & Recto & & & 557 Tyre Jas & $\mathrm{I}-5124.1(\mathrm{P})$ & Mr. Tyre \\
\hline $13 / 6$ & Recto & & & 556 Trenholme Dr. & II-80299.1 (P) & Norman W. Trenholme \\
\hline $13 / 7$ & Recto & & $\begin{array}{l}555, \text { Judge } \\
\text { Torrance }\end{array}$ & 555 Torrance Judge & $\mathrm{I}-0.15 .1$ (D) & Mr. Torrance \\
\hline $13 / 8$ & Recto & & & 554 Taylor ?olen? Mrs & [Not Confirmed] & \\
\hline $13 / 9$ & Recto & & & 553 Thomas Wolferstan & $\mathrm{I}-48794.1(\mathrm{D})$ & Francis Wolferstan Thomas \\
\hline $13 / 10$ & Recto & & $\begin{array}{l}\text { 552, Alderman } \\
\text { Taylor }\end{array}$ & 552 Taylor Ald & [Not Confirmed] & \\
\hline $13 / 11$ & Verso & & & 551 Turnbull Robt & $\mathrm{I}-21335.1(\mathrm{D})$ & Robert Turnbull \\
\hline $13 / 12$ & Verso & & $\begin{array}{l}\text { 550, Rev. Dr. } \\
\text { Taylor }\end{array}$ & 550 Taylor Dr. & $\mathrm{I}-4146.1$ (D) & Rev. Doctor Taylor \\
\hline $13 / 13$ & Verso & & 549, Thompson & 549 Thompson (?) M & $\mathrm{I}-11044.1(\mathrm{P})$ & George Thompson \\
\hline $13 / 14$ & Verso & & & 548 Tylee Miss & I-12203.1 (D) & Miss Tylee \\
\hline $13 / 15$ & Verso & & 547 & 547 Torrance Miss Sheppard & [Not Confirmed] & \\
\hline $13 / 16$ & Verso & & $\begin{array}{l}546, \text { James } \\
\text { Torrance }\end{array}$ & 546 Torrance Jas & $\mathrm{I}-2259.1(\mathrm{D})$ & James Torrance \\
\hline $13 / 17$ & Verso & 61603 & $\begin{array}{l}545, \text { Tabb } \\
\text { (hardware) }\end{array}$ & 545 Tabb Hdware & $\mathrm{I}-9844.1(\mathrm{P})$ & W. R. Tabb \\
\hline $13 / 18$ & Verso & & $\begin{array}{l}544, \text { Terrier } \\
\text { Torrance }\end{array}$ & 544 Torrance Terrier & [Not Confirmed] & \\
\hline
\end{tabular}


Album Page \#29, Revised Page 34, Sitters V \& U

\begin{tabular}{|l|l|l|l|l|l|l|}
\hline $\mathbf{P g} / \mathbf{P h}$ & $\mathbf{R} / \mathbf{V}$ & $\begin{array}{c}\text { Marks } \\
\text { (Neg. \#) }\end{array}$ & \multicolumn{1}{|c|}{ Inscriptions } & $\begin{array}{c}\text { Corresponding Index Book } \\
\text { Entry }\end{array}$ & \multicolumn{1}{|c|}{ Identifying Match } \\
[Not Confirmed], Only & \\
woman on page & \\
\hline $29 / 1$ & Recto & & & 568 Viau Charles Mrs & & [Unidentified Man] \\
\hline $29 / 2$ & Recto & & & & & [Unidentified Man] \\
\hline $29 / 3$ & Recto & & & & & [Unidentified Man] \\
\hline $29 / 5$ & Recto & & & & $\begin{array}{l}\text { II-61725.0.1 (P), II- } \\
61765.0 .1(P)\end{array}$ & Henry G. Vennor \\
\hline $29 / 6$ & Recto & & & 564 Vennor H & I-14491.1 (D) & James Kyle Urquhart \\
\hline $29 / 7$ & Recto & & 400 & Urquhart Jas & I-8612.1 (D) & Alex Urquhart \\
\hline
\end{tabular}


Album Page \#36, Revised Page 35, Sitters W

\begin{tabular}{|c|c|c|c|c|c|c|}
\hline $\mathbf{P g} / \mathbf{P h}$ & $\mathbf{R} / \mathbf{V}$ & $\begin{array}{l}\text { Marks } \\
\text { (Neg. \#) }\end{array}$ & Inscriptions & $\begin{array}{l}\text { Corresponding Index Book } \\
\text { Entry }\end{array}$ & Identifying Match & Identifying Information \\
\hline $36 / 1$ & Recto & 62710 & & 569 Wonham W 36-1 & II-41268.1 (D) & W. B or W. R. Wonham \\
\hline $36 / 2$ & Recto & & & 570 Watson wig & $\mathrm{I}-11451.1(\mathrm{D})$ & John Watson \\
\hline $36 / 3$ & Recto & & & 571 Wilson Adorne? & [Not Confirmed] & \\
\hline $36 / 4$ & Recto & & & 572 Williams & [Not Confirmed] & \\
\hline $36 / 5$ & Recto & & & 573 Winks Henry & I-14690.1 (P) & George Winks \\
\hline $36 / 6$ & Recto & & & 574 Ward (Hamilton) & $\mathrm{I}-14037.1(\mathrm{P})$ & Col Lt Ward \\
\hline $36 / 7$ & Recto & & & & & [Unidentified Man] \\
\hline $36 / 8$ & Recto & & & & & [Unidentified Man] \\
\hline $36 / 9$ & Recto & & & 577 Wallis & II-59400.1 (D) & H. Wallis \\
\hline $36 / 10$ & Recto & & & & & [Unidentified Man] \\
\hline $36 / 11$ & Verso & & $\begin{array}{l}579, \mathrm{Wm} \\
\text { Workman }\end{array}$ & 579 Workman Wm 36-1bk & $\mathrm{I}-22186.1(\mathrm{D})$ & William Workman, mayor \\
\hline $36 / 12$ & Verso & & $\begin{array}{l}580, \text { Dr. } \\
\text { Wanless }\end{array}$ & 580 Wanless Dr. 36-2bk & II-60268.1 (D) & \\
\hline $36 / 13$ & Verso & & 581, Whitehead & 581 Whitehead Lord & $\mathrm{I}-5756.1(\mathrm{P})$ & P. T. Whitehead \\
\hline $36 / 14$ & Verso & & 582, O. S. Wood & 582 Wood S. O. & $\begin{array}{l}\text { M6295 (D) } \\
\text { Steelengraving by } \\
\text { Alexander Hay Richie }\end{array}$ & Oran Squire Wood \\
\hline $36 / 15$ & Verso & & $\begin{array}{l}\text { 583, Simpson? } \\
\text { Walker }\end{array}$ & 583 Walker Lawyer & [Not Confirmed] & \\
\hline $36 / 16$ & Verso & & $\begin{array}{l}\text { 584, Rev. E. } \\
\text { Wood }\end{array}$ & 584 Wood Revd E & $\mathrm{I}-503.1$ (D) & Rev Edmund Wood \\
\hline $36 / 17$ & Verso & & 585, Weir & 585 Weir Bank? & I-3943.1 (D) & William Weir \\
\hline $36 / 18$ & Verso & & $\begin{array}{l}\text { 586, Richard } \\
\text { White }\end{array}$ & 586 White Richard & $\mathrm{I}-8146.1(\mathrm{D})$ & Richard White \\
\hline $36 / 19$ & Verso & & $\begin{array}{l}\text { 587, Thos White } \\
\text { M.P. }\end{array}$ & 587 White Thos MP 36-9bk & $\begin{array}{l}\text { MIKAN no. } 3488232 \text { by } \\
\text { Topley, LAC (D) }\end{array}$ & $\begin{array}{l}\text { Hon. Thomas White, M.P., } \\
\text { (Cardwell, Ont.) }\end{array}$ \\
\hline $36 / 20$ & Verso & & $\begin{array}{l}588, \text { Wand } \\
\text { (contractor) }\end{array}$ & 588 Wand $36-10 \mathrm{bk}$ & $\mathrm{I}-64537.1(\mathrm{D})$ & Alex Wand \\
\hline
\end{tabular}


Album Page \#32, Revised Page 36, Sitters W

\begin{tabular}{|c|c|c|c|c|c|c|}
\hline $\mathbf{P g} / \mathbf{P h}$ & $\mathbf{R} / \mathbf{V}$ & $\begin{array}{l}\text { Marks } \\
\text { (Neg. \#) }\end{array}$ & Inscriptions & $\begin{array}{l}\text { Corresponding Index Book } \\
\text { Entry }\end{array}$ & Identifying Match & Identifying Information \\
\hline $32 / 1$ & Recto & & & & & [Unidentified Man] \\
\hline $32 / 2$ & Recto & & & $\begin{array}{l}590 \text { Wilson J A ? Herald } \\
\text { Printer }\end{array}$ & $\mathrm{I}-31239.1$ (D) & Mr. Wilson \\
\hline $32 / 3$ & Recto & & & & & [Unidentified Man] \\
\hline $32 / 4$ & Recto & & & 592 Wright Revd & II-63408.1 (D) & Rev Dr William Wright \\
\hline $32 / 5$ & Recto & & & 593 Whitney Stephen \& Son & $\mathrm{I}-491.1(\mathrm{P})$ & Mr. Whitney M. P. P. \\
\hline $32 / 6$ & Recto & & & & & [Unidentified Man] \\
\hline $32 / 7$ & Recto & 33242 & & 595 Walker Joe & I-3366.1 (D) & Joseph Walker \\
\hline $32 / 8$ & Recto & & & 596 Whitehead Col 32-8 & I-20952.1 (D) & $\begin{array}{l}\text { Identified in Victoria Rifles } \\
\text { Composite - E. A. } \\
\text { Whitehead }\end{array}$ \\
\hline $32 / 9$ & Recto & & & 597 Waddell S 32-9 & $\mathrm{I}-13847.1(\mathrm{D})$ & Samuel Waddell \\
\hline $32 / 10$ & Recto & & & 598 Waddell S 32-10 & I-25119.1 (D) & $\begin{array}{l}\text { Samuel Waddell \& Mary } \\
\text { Caroline MacKay }\end{array}$ \\
\hline $32 / 11$ & Verso & & & 599 Watson Misses & $\begin{array}{l}{[\text { Not Confirmed], Only }} \\
\text { portrait of two women } \\
\text { on page }\end{array}$ & \\
\hline $32 / 12$ & Verso & & & 600 Wolf \& Wife \& Child & $\mathrm{I}-1036.1(\mathrm{P})$ & Mr Wolf \\
\hline $32 / 13$ & Verso & & & $\begin{array}{l}\text { 601 Whitney Miss like } \\
\text { Florence? 32-3bk }\end{array}$ & I-49957.1 (D) & F. A. Whitney \\
\hline $32 / 14$ & Verso & & & 602 Wheeler Mrs & [Not Confirmed] & \\
\hline $32 / 15$ & Verso & & & 603 Wheeler Miss & II-54612.1 (D) & Miss Wheeler \\
\hline $32 / 16$ & Verso & & & & & [Unidentified Man] \\
\hline
\end{tabular}


Album Page \#14, Revised Page 37, Sitters Y

\begin{tabular}{|l|l|l|l|l|l|l|}
\hline Pg/Ph & R/V & $\begin{array}{c}\text { Marks } \\
\text { (Neg. \#) }\end{array}$ & \multicolumn{1}{|c|}{ Inscriptions } & $\begin{array}{c}\text { Corresponding Index Book } \\
\text { Entry }\end{array}$ & \multicolumn{1}{|c|}{ Identifying Match } & Identifying Information \\
\hline $14 / 1$ & Recto & & & 609 Young G Paper C ? 14-1 & [Not Confirmed] & \\
\hline $14 / 2$ & Recto & & & 608 Young Miss G Brother ? & I-3201.1 (D) & Mrs. John Frazer \\
\hline $14 / 3$ & Recto & & & 607 Yuile & II-55968.1 (D) & David Yuile \\
\hline $14 / 4$ & Recto & & & 606 Yuile & [Not Confirmed] & \\
\hline $14 / 5$ & Recto & & & 605 Young John Honble & I-4162.1 (D) & Hon. John Young \\
\hline
\end{tabular}


Album Page \#37, Revised Page 38, Sitters Unknown

\begin{tabular}{|l|l|l|l|c|c|c|}
\hline $\mathbf{P g} / \mathbf{P h}$ & $\mathbf{R} / \mathbf{V}$ & $\begin{array}{c}\text { Marks } \\
\text { (Neg. \#) }\end{array}$ & Inscriptions & $\begin{array}{c}\text { Corresponding Index Book } \\
\text { Entry }\end{array}$ & Identifying Match & Identifying Information \\
\hline $37 / 1$ & Recto & & & & & [Unidentified Man] \\
\hline $37 / 2$ & Recto & & & & & [Unidentified Man] \\
\hline $37 / 3$ & Recto & & & & & [Unidentified Man] \\
\hline $37 / 4$ & Recto & & & & & [Unidentified Man] \\
\hline
\end{tabular}


Album Page \#39, Revised Page 39, Sitters Unknown

\begin{tabular}{|l|l|l|l|l|l|l|}
\hline $\mathbf{P g} / \mathbf{P h}$ & $\mathbf{R} / \mathbf{V}$ & $\begin{array}{c}\text { Marks } \\
\text { (Neg. \#) }\end{array}$ & Inscriptions & $\begin{array}{c}\text { Corresponding Index Book } \\
\text { Entry }\end{array}$ & Identifying Match & Identifying Information \\
\hline $39 / 1$ & Recto & & & & & [Unidentified Woman] \\
\hline $39 / 2$ & Recto & & & & & [Unidentified Man] \\
\hline $39 / 3$ & Recto & & & & & [Unidentified Man] \\
\hline $29 / 4$ & Recto & & & & & [Unidentified Man] \\
\hline $39 / 5$ & Recto & & & & & [Unidentified Man] \\
\hline $39 / 6$ & Recto & & & & & [Unidentified Man] \\
\hline $39 / 7$ & Recto & & & & [Unidentified Man] \\
\hline
\end{tabular}




\section{APPENDIX III: Related Documents Transcription}

This appendix provides a transcription, to the best of the author's ability, of the negative numbers and names as found on the four supporting documents. The four tables correspond to the four sheets of paper. In each table, the bolded lines indicating the fold marks that were used to demark columns.

At the top of each sheet are inscribed numbers 1-4. Below and in the first column of the table, the penciled Inglis negative numbers are listed. The numbers designated "Lead Numbers" by the author, and indicated in annotated illustration of the related document (ill. 6; pg. 25), are transcribed and bolded. The first two or three digits of the numbers designated "Following Numbers" in the same annotated illustration are placed in square brackets to indicate that they have been reconstructed by the author; the relationship between the "Lead Numbers" and the "Following Numbers" is explained on pages 23-24 of thesis. ${ }^{66}$ In the second column are the penciled names of individuals and occasionally their occupation. The handwriting on the related documents has been smudged and is illegible in some places. If an entire word is illegible the letters that are legible have been transcribed with question marks in square brackets representing the estimated number of illegible characters. Some negative numbers are listed but do not have a corresponding name - these are indicated as "[No Entry]". Also, in those cases where an inscription has been scratched out, the underlying inscription has been transcribed in cross-strike font. In the third column, the presence of check marks are indicated by a " $\sqrt{ }$ ".

\footnotetext{
${ }^{66}$ One exception to this method is that on Related Document \#3, (Pg. 94), the negative number " 34865 " was written in amongst other negative numbers that begin with " 36 ". The author believes this is not meant disrupt the "Lead Number" above, so the "Following Numbers" below "34865" maintain the "[36]" from the above "Lead Number".
} 


\begin{tabular}{|c|c|c|c|c|c|}
\hline & $\underline{1}$ & & & $\underline{1}$ & \\
\hline 29412 & Geo P[??????] & $\sqrt{ }$ & 31856 & Po[??] & $\sqrt{ }$ \\
\hline [29]435 & Mrs Scott & & {$[31] 861$} & [No Entry] & \\
\hline$[29] 453$ & Dr Trenholme & & [31]971 & James Tyne & $\sqrt{ }$ \\
\hline$[29] 455$ & [No Entry] & & [31]989 & Mr Angus & \\
\hline$[29] 433$ & Prof. & & {$[31] 191$} & Mr Ogilvie & \\
\hline [29]486 & Revd Mr. Gibson & & 32021 & Dr Matherson & $\sqrt{ }$ \\
\hline [29]698 & Mr. Darling & & [32]017 & Easton & $\sqrt{ }$ \\
\hline$[29] 726$ & [???????] & & {$[32] 053$} & Claxton & \\
\hline [29]714 & Mi[?] & & {$[32] 050$} & $\begin{array}{c}\text { Robertson } \\
\text { Lawyer }\end{array}$ & \\
\hline$[29] 782$ & H Vennor & $\sqrt{ }$ & {$[32] 067$} & A Ch[??]per & $\sqrt{ }$ \\
\hline$[29] 784$ & Alexander & & {$[32] 101$} & D. Parker & $\sqrt{ }$ \\
\hline [29]900 & Court & & [32]124 & Rev Campbell & \\
\hline [29]924 & Macfarlane & & {$[32] 125$} & Col McKay & \\
\hline 30143 & Mackay & & {$[32] 170$} & Wm Workman & $\sqrt{ }$ \\
\hline$[30] 176$ & Mathieson & & {$[32] 200$} & Lawyer R & \\
\hline$[30] 210$ & Geology & & {$[32] 251$} & Ogilvie dead & \\
\hline$[30] 421$ & [No Entry] & & {$[32] 237$} & [????] & \\
\hline$[30] 502$ & [No Entry] & & {$[32] 205$} & Capt Gale & $\sqrt{ }$ \\
\hline$[30] 527$ & Morrice & & & & \\
\hline 31764 & $\mathrm{~J}$ Ferrier & & & & \\
\hline$[31] 777$ & Millwright & & & & \\
\hline$[31] 793$ & Gilbert Scott & $\sqrt{ }$ & & & \\
\hline$[31] 841$ & Lorn McDougall & $\sqrt{ }$ & & & \\
\hline [31]842 & Geo Drummond & & & & \\
\hline
\end{tabular}




\begin{tabular}{|c|c|c|c|c|c|c|c|c|}
\hline & $\underline{2}$ & & & $\underline{2}$ & & & $\underline{2}$ & \\
\hline 32837 & Jas McKay & $\sqrt{ }$ & 33585 & $\begin{array}{c}\text { Lovell Mr \& } \\
\text { Mrs }\end{array}$ & $\sqrt{ }$ & 34358 & Mrs Sharpley & $\sqrt{ }$ \\
\hline$[328] 78$ & $\begin{array}{c}\text { Alex } \\
\text { Hammond }\end{array}$ & $\sqrt{ }$ & 33591 & Masquerade & & {$[343] 62$} & [No Entry] & \\
\hline [32]964 & Alex Urquhart & $\sqrt{ }$ & {$[335] 90$} & Horton $\mathrm{Jr}$ & & {$[34] 437$} & Mrs? & \\
\hline [32]954 & $\begin{array}{l}\text { Sr John } \\
\text { H[????] }\end{array}$ & & {$[33] 873$} & D Ross & & {$[34] 504$} & Waddell & $\sqrt{ }$ \\
\hline [32]980 & Childs & & [33]917 & Routh Jr & $\sqrt{ }$ & [34]553 & D Ross & \\
\hline 33091 & [No Entry] & & [33]932 & Whitneys & $\sqrt{ }$ & {$[34] 582$} & McIntoch & \\
\hline [33]081 & McKay & & [33]989 & [No Entry] & & [34]605 & [No Entry] & \\
\hline$[33] 120$ & Bishop & & 34014 & Professor & & {$[34] 611$} & [No Entry] & \\
\hline 33140 & Perth & $\sqrt{ }$ & {$[34] 034$} & Cowan T[??] & & {$[34] 614$} & [No Entry] & \\
\hline [33]145 & $\begin{array}{c}\text { B1[????????] } \\
\text { [???] }\end{array}$ & & {$[34] 068$} & Col Dyde & $\sqrt{ }$ & {$[34] 626$} & Morland & $\sqrt{ }$ \\
\hline 33201 & Mrs D father & & {$[340] 73$} & Morland & $\sqrt{ }$ & {$[34] 667$} & Waddell & $\sqrt{ }$ \\
\hline [33]242 & Jas Walker & $\sqrt{ }$ & {$[34] 103$} & $\begin{array}{c}\text { Custom House } \\
\text { Man }\end{array}$ & & {$[34] 717$} & McGibbin & \\
\hline [33]284 & Reynolds & & 34131 & [No Entry] & & {$[34] 725$} & Sir H. Allan & $\sqrt{ }$ \\
\hline [33]286 & D. Ross & $\sqrt{ }$ & {$[341] 38$} & Jas Torrance & & {$[34] 772$} & Bremer & $\sqrt{ }$ \\
\hline [33]341 & Bishop & & [34]169 & [No Entry] & & & & \\
\hline [33]354 & Ogilvie & & [34]199 & $\mathrm{Wm}$ & & & & \\
\hline$[33] 411$ & Menkies & $\sqrt{ }$ & {$[34] 226$} & $\begin{array}{c}\text { Statuette } \\
\text { figure }\end{array}$ & & & & \\
\hline$[33] 430$ & [No Entry] & & {$[34] 283$} & [No Entry] & & & & \\
\hline$[33] 506$ & $\begin{array}{c}\text { Mulholland } \\
\text { W[??] }\end{array}$ & & {$[34] 300$} & [No Entry] & & & & \\
\hline \multirow[t]{5}{*}{ [33]556 } & [No Entry] & & {$[34] 312$} & [?] Kay & $\sqrt{ }$ & & & \\
\hline & & & {$[34] 322$} & [No Entry] & & & & \\
\hline & & & {$[34] 345$} & Prince Arthur & & & & \\
\hline & & & [343]46 & [No Entry] & & & & \\
\hline & & & {$[343] 47$} & [No Entry] & & & & \\
\hline
\end{tabular}




\begin{tabular}{|c|c|c|c|c|c|}
\hline & $\underline{\mathbf{3}}$ & & & $\underline{\mathbf{3}}$ & \\
\hline 34826 & Military & & 36660 & $\begin{array}{l}\text { Artillery Drill } \\
\text { Instructor }\end{array}$ & $\sqrt{ }$ \\
\hline$[34] 833$ & Col McPherson & & {$[36] 661$} & $25^{\text {th }}$ Officer & \\
\hline 35002 & Findlay family & & {$[36] 718$} & Col Anthony & $\sqrt{ }$ \\
\hline 35388 & Carson Tom & & {$[36] 720$} & $\begin{array}{c}\text { Capt } \\
\text { Greensheilds }\end{array}$ & $\sqrt{ }$ \\
\hline$[35] 429$ & Prince Arthur & & {$[36] 823$} & Ribb Officer & \\
\hline$[35] 444$ & Well Lt. man & & {$[36] 824$} & $\mathrm{Col}$ & \\
\hline$[35] 461$ & $\begin{array}{c}\text { T[????]te } \\
\text { Scotchman }\end{array}$ & & {$[36] 886$} & Music Teacher & \\
\hline$[35] 551$ & M[??]ie [??] & & [36]925 & Theodore Hall & \\
\hline$[35] 545$ & Heyesager & & [36]969 & Wm Carpenter & $\sqrt{ }$ \\
\hline$[35] 594$ & Grey Stallion & & 34865 & Dr Wanless & $\sqrt{ }$ \\
\hline$[35] 619$ & $\begin{array}{l}\text { Mrs N. McIntoch } \\
\text { \& Children }\end{array}$ & & {$[36] 858$} & Mr. Brown & \\
\hline$[35] 692$ & Builder & & {$[36] 896$} & Lieut Tyles & $\sqrt{ }$ \\
\hline$[35] 700$ & Honble J. Young & & [36]924 & T L W Loren & $\sqrt{ }$ \\
\hline$[35] 795$ & Henry Lyman & $\sqrt{ }$ & & & \\
\hline$[35] 927$ & Artillery Officer & & & & \\
\hline$[35] 940$ & $\begin{array}{c}\text { Miss De } \\
\text { Rocheblave }\end{array}$ & $\sqrt{ }$ & & & \\
\hline 36119 & [???] & & & & \\
\hline$[36] 358$ & Young Blackwell & $\sqrt{ }$ & & & \\
\hline$[36] 379$ & Johnny McIntoch & $\sqrt{ }$ & & & \\
\hline$[36] 450$ & Capt Whitehead & & & & \\
\hline$[36] 558$ & Major Crawford & & & & \\
\hline$[36] 618$ & Alfred Dutton & $\sqrt{ }$ & & & \\
\hline$[36] 624$ & Bank Manager & & & & \\
\hline
\end{tabular}




\begin{tabular}{|c|c|c|c|}
\hline & 4 & & $\underline{4}$ \\
\hline 37471 & Prince Arthur & 39423 & Brick Man Chester \\
\hline 37620 & Mitchell Boy & [39]491 & Galt [?????] \\
\hline 38870 & Highlander & {$[39] 502$} & Galt \\
\hline$[38] 709$ & $\begin{array}{c}\text { Custom House } \\
\text { Mme }\end{array}$ & {$[39] 522$} & Officer French \\
\hline$[38] 847$ & Dr Sutherland & & \\
\hline 38419 & Dr Dorchester & & \\
\hline 38003 & Highland Medalist & & \\
\hline$[38] 035$ & “ “ & & \\
\hline$[38] 044$ & M[????] Brother & & \\
\hline$[38] 072$ & Wm Barclay & & \\
\hline$[38] 064$ & Delisle Hardware & & \\
\hline [38]104 & Notary & & \\
\hline$[38] 339$ & Cabinet McMaster & & \\
\hline$[38] 530$ & $\begin{array}{c}\text { Cha[?] [????] } \\
\text { [?????] }\end{array}$ & & \\
\hline 38875 & $\begin{array}{c}\mathrm{R}[? ? ?][? ? ? ? ?] \\
\text { Highlander }\end{array}$ & & \\
\hline [38]902 & $\begin{array}{c}\mathrm{G} \text { [????] [????] } \\
\text { [????] }\end{array}$ & & \\
\hline 39197 & Capt [???] [??????] & & \\
\hline 39411 & Revd Green & & \\
\hline
\end{tabular}




\section{APPENDIX IV: Negative Number Correlations between}

Album Pages and Related Documents

This appendix records the negative numbers that are inscribed on photographs in the 39 disbound album pages, and the penciled numbers on the four related documents (see Appendix III for the transcription of these sheets). The first column labeled, "Revised Pg/API \#", provides the revised page number of the album page that holds the portraits, followed by a back/slash and the previous album page number as identified by the "Album Page Identity Number" inscribed in pencil on the top left hand side of each page. The photograph number is assigned by the author; this number records the position of the image on the page, as ordered from the left to right, top row to bottom row of the photographs in found in the second column. The third column lists the photograph's corresponding index book entry as determined by the "Portrait Sequence Numbers". The fourth column lists the inscribed negative number as it appears on the photograph. The fifth column, "Related Document \#" records the related document where the negative number is found. If the negative number is not found on the related documents, this is indicated here by the phrase "Not Found". Negative numbers, which are higher than the range of numbers that appears on the related documents lists (29412 - 39522) are indicated in this column by the phrase "Higher than Lists". There are no negative numbers in the photographs on the album page photographs that are lower than 29412 . The sixth and final column lists the corresponding entries for the negative numbers found on the related documents. The single, definite match that has been made is bolded and is described at length in the Critical Analysis chapter, in the section "Intellectual Organization: Relationship between Album Pages and Related Documents (pg. 51) and in the section "Attribution of Photographs (pg. 55). 


\begin{tabular}{|c|c|c|c|c|c|}
\hline $\begin{array}{l}\text { Revised } \\
\text { Pg/API } \\
\#\end{array}$ & $\mathbf{P h}$ & $\begin{array}{l}\text { Corresponding Index } \\
\text { Book Entry }\end{array}$ & $\begin{array}{l}\text { Neg. } \\
\#\end{array}$ & Related Document \# & $\begin{array}{c}\text { Corresponding } \\
\text { Related } \\
\text { Document Entry }\end{array}$ \\
\hline $1 / 33$ & 7 & $\begin{array}{l}7 \text { Hugh Allan, Definite } \\
\text { Match }\end{array}$ & 34721 & Not Found & 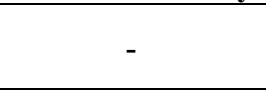 \\
\hline $1 / 33$ & 16 & $\begin{array}{l}25 \text { Archibald Gardener, } \\
33-6 \text { bk, Not Confirmed }\end{array}$ & 39514 & Not Found & - \\
\hline $7 / 5$ & 7 & No Entry Confirmed & 32179 & Not Found & - \\
\hline $7 / 5$ & 8 & No Entry Confirmed & 33556 & $\begin{array}{l}\text { Found, Related Document } \\
\qquad \# 2\end{array}$ & $\begin{array}{c}{[\text { No }} \\
\text { Corresponding } \\
\text { Entry] }\end{array}$ \\
\hline $11 / 23$ & 16 & No Entry Confirmed & 59402 & Higher than lists & - \\
\hline $12 / 15$ & 13 & No Entry Confirmed & 29572 & Not Found & - \\
\hline $12 / 15$ & 14 & $\begin{array}{l}213 \text { Gilmour, Probable } \\
\text { Match }\end{array}$ & 56626 & Higher than lists & - \\
\hline $12 / 15$ & 15 & No Entry Confirmed & 40841 & $\begin{array}{c}\text { Has been cut out of James } \\
\text { Inglis Picture Book, M6591 } \\
39570-41852\end{array}$ & - \\
\hline $12 / 15$ & 19 & No Entry Confirmed & 42798 & Higher than lists & - \\
\hline $12 / 15$ & 17 & No Entry Confirmed & 32290 & Not Found & - \\
\hline $15 / 18$ & 14 & $\begin{array}{l}245 \text { Harrington Dr., } \\
\text { Probable Match }\end{array}$ & 38771 & Not Found & - \\
\hline $15 / 18$ & 16 & $\begin{array}{l}242 \text { Haldane J, Possible } \\
\text { Match }\end{array}$ & 35461 & $\begin{array}{l}\text { Found, Related Document } \\
\qquad \# 3\end{array}$ & $\begin{array}{c}\text { T[????]te } \\
\text { Scotchman } \sqrt{ }\end{array}$ \\
\hline $16 / 10$ & 14 & No Entry Confirmed & 38860 & Not Found & - \\
\hline $17 / 6$ & 10 & $\begin{array}{c}\text { 296 Jones Jr, Definite } \\
\text { Match }\end{array}$ & 32954 & $\begin{array}{l}\text { Found, Related Document } \\
\qquad 2\end{array}$ & Sr John H[????] \\
\hline $19 / 2$ & 6 & $\begin{array}{l}\text { 314 Leggatt Boots \& } \\
\text { Shoes, Probable Match }\end{array}$ & 38051 & Not Found & - \\
\hline $19 / 2$ & 11 & No Entry Confirmed & 58858 & Higher than lists & \\
\hline $19 / 2$ & 19 & $\begin{array}{l}\text { 327, Hon. Laviolette, } \\
\text { Definite Match }\end{array}$ & 64540 & Higher than lists & - \\
\hline $21 / 35$ & 16 & $\begin{array}{c}358 \text { Massey Revd } 379 \\
\text { Murphy J, Probable } \\
\text { Match } \\
\end{array}$ & 33540 & Not Found & - \\
\hline $23 / 8$ & 12 & $\begin{array}{c}426 \text { McKay, Probable } \\
\text { Match }\end{array}$ & 37711 & Not Found & - \\
\hline $24 / 4$ & 8 & $\begin{array}{l}433 \text { Nelson H. W. top, } \\
\text { Probable Match }\end{array}$ & 55384 & Higher than lists & - \\
\hline $30 / 22$ & 6 & $\begin{array}{l}517 \text { Sharpley Mrs., } \\
\text { Probable Match }\end{array}$ & 34358 & $\begin{array}{c}\text { Found, Related Document } \\
\qquad 2\end{array}$ & Mrs. Sharpley $\sqrt{ }$ \\
\hline $30 / 22$ & 19 & No Entry Confirmed & 35079 & Not Found & - \\
\hline $30 / 22$ & 20 & No Entry Confirmed & 29522 & Not Found & - \\
\hline $31 / 21$ & 15 & $\begin{array}{l}529 \text { Slack Revd, Definite } \\
\text { Match }\end{array}$ & 32886 & Not Found & - \\
\hline $33 / 13$ & 17 & $\begin{array}{l}545 \text { Tabb Hdware, } \\
\text { Probable Match }\end{array}$ & 61603 & Higher than lists & - \\
\hline $36 / 32$ & 7 & $\begin{array}{c}595 \text { Walker Joe, Definite } \\
\text { Match }\end{array}$ & 33242 & Not Found & - \\
\hline
\end{tabular}




\section{BIBLIOGRAPHY}

\section{Primary Resources:}

Bibliothèque nationale du Québec. "Annuaires Lovell de Montréal et sa banlieue (18421999)" Digitized Collection. Accessed July 20, 2012.

http://bibnum2.bnquebec.ca/bna/lovell/.

Borthwick, J Douglas. Montreal, its History with Photographs of Many of it's Principal Citizens. Drysdale and Co., Stationary and Booksellers: Montreal, 1875.

Canadian Intellectual Property Office. "Canadian Patents Database," Accessed July 20, 2012. http://brevets-patents.ic.gc.ca/opic$\mathrm{cipo} / \mathrm{cpd} / \mathrm{eng} / \mathrm{patent} / 58935 /$ summary.html?query=Gilson\&start=1\&num=50\&typ $\mathrm{e}=$ basic_search\#View_Images

Gilson, Franklin H.. 1897. Separable Book. U.S. Patent 594,203, filed February 15, 1897, issued November 23, 1897.

Library and Archives Canada. "Canadian Illustrated News: Images in the news: 18691883." Accessed on July 20, 2012.

http:/www.collectionscanada.gc.ca/databases/cin/001065-119.01-

e.php?\&nl_id_nbr=1014\&brws_s=1\&\&PHPSESSID=7hi1kv8vs98rjo5o2h505qk 264

"Montreal General Hospital," The Canada Medical Record. Montreal: J. Lovell \& Son, November 1891.

The International Railway and Steam Navigation Guide. Montreal: C. R. Chrisolm \& Bros., August 1875.

Vennor's Almanac and Weather Record. Montreal: J. Lovell \& Son, 1878-79.

Wilson, Edward L. ed. "Award of the Prizes: Competitors for the Genre or Composition Prize," The Philadelphia Photographer, 6 (November 1869): 361.

\section{Editions of James Inglis' Book, Artistic Lighting:}

Inglis, James. Artistic Lighting. Chicago: The Photo-Beacon Co, 1897.

Inglis, James \& Todd F. Dundas. Artist Lighting, to which is added, "At Home"

Portraiture with Daylight and Flashlight. Chicago: The Photo-Beacon, 1905. 


\section{Secondary Sources:}

\section{History of Photography}

About, Ilsen and Clément Chéroux. "L'histoire par la photographie." Études photographiques 10 (November 2001). Accessed12 July, 2012. http://etudesphotographiques.revues.org/index261.html.

Batchen, Geoffrey. Each Wild Idea: Writing, Photography, History. Massachusetts: MIT Press, 2001

Edwards, Elizabeth \& Janice Hart, ed.. Photographs, Objects, Histories: On the Materiality of Images. London; New York: Routledge, 2004.

Marien, Mary Warner. Photography: A Cultural History. 3rd ed. ed. Upper Saddle River, NJ: Pearson Prentice Hall, 2011 ie. 2010.

Reilly, James M. The Albumen \& Salted Paper Book: The History and Practice of Photographic Printing, 1840-1895. Rochester: Light Impressions Corporation: 1980.

\section{Nineteenth Century Portraiture Studios}

Greenhill, Ralph. Early Photography in Canada. Toronto: Oxford University Press, 1965.

Greenhill, Ralph \& Andrew Birrell. Canadian Photography: 1839-1920. Toronto: Coach House Press, 1979.

Joan L, Severa. Dressed for the Photographer: Ordinary Americans and Fashion, 18401900. Ohio: The Kent State University Press, 1995

McCauley, Anne. Industrial Madness: Commercial Photography in Paris, 1848-1871. New Haven, Connecticut: Yale University Press, 1994.

--------. Likenesses: Portrait Photography in Europe, 1850-1870. Exhibition Catalogue. Albuquerque: Art Museum/University of New Mexico, 1981.

Tagg, John. "A Democracy of the Image: Photographic Portraiture and Commodity Production". The Burden of Representation: Essays on Photographies and Histories. London: Macmillian, 1988.

The Studio, edited by Time-Life Books. Rev. ed. ed. Alexandria, Va.: Time-Life Books, 1982. 


\section{Photographic Albums}

Bann, Stephen ed., Art and the Early Photographic Album. Washington, D.C.: National Gallery of Art, 2011.

Curtis, Verna Posever, Photographic Memory: The Album in the Age of Photography. Washington: Library of Congress: New York: Aperture, 2011.

Di Bello, Patrizia. Women's Albums and Photography in Victorian England: Ladies, Mothers, and Flirts. Aldershot, UK: Ashgate, 2007.

Langford, Martha. Suspended Conversations: The Afterlife of Memory in Photographic Albums. Montreal: McGill-Queen's University Press, 2001.

Levine, Barbara \& Stephanie Snyder. Snapshot Chronicles: Inventing the American Photo Album. Exhibition catalogue. New York: Princeton Architectural Press; Portland Oregon: Douglas F. Cooley Memorial Art Gallery, Reed College, 2006.

Siegel, Elizabeth. Galleries of Friendship and Fame: A History of Nineteenth-Century American Photograph Albums. New Haven [Conn.]: Yale University Press, 2010.

Weston, Heather. Bookcraft: Techniques for Binding, Folding, and Decorating to Create Books. London: Quarto Publishing, 2008.

\section{James Inglis}

McCord Museum.’Inglis, James.” Accessed July 20, 2012. http://www.museemccord.qc.ca/scripts/explore.php?Lang=1\&tableid=1\&tablename=artist\&elemen tid $=00260 \_$true.

Reichstein, Irwin. "James Inglis, Montreal, Rochester, Chicago". Part 1. Photographica Canadiana. March/April 1997. P. 5-9.

--------. "James Inglis, Montreal, Rochester, Chicago". Part 2. Photographica Canadiana. May/June 1997. P.6-10.

Triggs, Stanley G. "A Famous Composite Photograph". Composite Photographs. McCord Museum. Accessed July 20, 2012. http://www.mccordmuseum.qc.ca/en/keys/virtualexhibits/notmanstudio/themes/composites/page2.ht $\mathrm{ml}$ 


\section{William Notman}

Hall, Roger. The World of William Notman: The Nineteenth Century through a Master Lens, edited by Gordon Dodds \& Stanley Triggs. Toronto: McClelland \& Stewart, 1993.

Triggs, Stanley. William Notman: The Stamp of a Studio. Toronto: Art Gallery of Ontario 1985.

. William Notman's Studio : The Canadian Picture. Montréal: McCord Museum, 1992.

The Composite Photographs of William Notman, Montreal: McCord Museum of Canadian History, 1994.

"Notman Expands his business", The Man and the Studio. Online article: Virtual Museum Canada, McCord Museum, 2005.

\section{Biographical References}

Alexander, John. The Ogilvies of Montreal, with a Genealogical Account of the Descendants of their Grandfather, Archibald Ogilvie. Gazette: Montreal, 1904.

Canadian Heritage. "Royal Visits from 1786 to 1951 - Monarchy in Canada." Accessed on: July 20, 2012. http://pch.gc.ca/eng/1307123137189/1307123947930

Filteau, Hughette. "Henry Morgan." Dictionary of Canadian Biography Online. Accessed on July 20, 2012 http://www.biographi.ca/009004-119.01e.php?\&id_nbr=6313.

McGill University Library. "The Marjorie Howard Futcher Photo Collection.” Accessed July 20, 2012, http://digital.library.mcgill.ca/futcher/biography.php.

McCord Museum. "The McCord Museum - Its History.” Accessed July 20, 2012. http://www.mccord-museum.qc.ca/en/info/collection/.

McCord Museum. "Victoria Rifles of Canada fonds (P190): Administrative History Biographical Sketch.” Accessed on July 25, 2012. http://www.mccordmuseum.qc.ca/scripts/explore.php?Lang=1\&tableid=18\&tablename=fond\&elem entid $=46$ _true. 